MANUELA VIEIRA GIMENES

\title{
VIRIOPLÂNCTON NA AMAZÔNIA: ESTUDO DA DIVERSIDADE DOS VÍRUS DAS FAMÍLIAS PHYCODNAVIRIDAE E MYOVIRIDAE NOS RIOS NEGRO, SOLIMÕES E CUIEIRAS
}

Tese apresentada ao Programa de Pós-

Graduação em Microbiologia do Instituto de Ciências Biomédicas da Universidade de São Paulo, para a obtenção do Título de Doutor em Ciências. 
MANUELA VIEIRA GIMENES

\section{VIRIOPLÂNCTON NA AMAZÔNIA: ESTUDO DA DIVERSIDADE DOS VÍRUS DAS FAMÍLIAS PHYCODNAVIRIDAE E MYOVIRIDAE NOS RIOS NEGRO, SOLIMÕES E CUIEIRAS}

Tese apresentada ao Programa de PósGraduação em Microbiologia do Instituto de Ciências Biomédicas da Universidade de São Paulo, para a obtenção do Título de Doutor em Ciências.

Área de concentração: Microbiologia Orientadora: Profa. Dra. Dolores Ursula Mehnert 
DADOS DE CATALOGAÇÃO NA PUBLICAÇÃO (CIP)

Serviço de Biblioteca e Informação Biomédica do

Instituto de Ciências Biomédicas da Universidade de São Paulo

reprodução não autorizada pelo autor

Gimenes, Manuela Vieira.

Virioplâncton na Amazônia: estudo da diversidade dos vírus das famílias Phycodnaviridae e Myoviridae nos rios Negro, Solimões e Cuieiras / Manuela Vieira Gimenes. -- São Paulo, 2010.

Orientador: Dolores Ursula Mehnert.

Tese (Doutorado) - Universidade de São Paulo. Instituto de Ciências Biomédicas. Departamento de Microbiologia. Área de concentração: Microbiologia. Linha de pesquisa: Virologia ambiental

Versão do título para o inglês: Virioplankton in the Amazon: diversity study of viruses from Phycodnaviridae and Myoviridae families in the Negro, Solimões and Cuieiras rivers.

Descritores: 1. Vírus 2. Virioplâncton 3. Amazonas 4.

Ecossistema aquático 5. Água 6. Fitoplâncton I. Mehnert, Dolores Ursula II. Universidade de São Paulo. Instituto de Ciências

Biomédicas. Programa de Pós-Graduação em Microbiologia III. Título. 
Candidato(a): Manuela Vieira Gimenes.

Título da Tese: $\quad$ Virioplâncton na Amazônia: estudo da diversidade dos vírus das famílias Phycodnaviridae e Myoviridae nos rios Negro, Solimões e Cuieiras.

Orientador(a): Dolores Ursula Mehnert.

A Comissão Julgadora dos trabalhos de Defesa da Tese de Doutorado, em sessão pública realizada a ..................., considerou

\section{( ) Aprovado(a) ( ) Reprovado(a)}

\begin{tabular}{|c|c|}
\hline Examinador(a): & $\begin{array}{l}\text { Assinatura: } \\
\text { Nome: ......... } \\
\text { Instituição: . }\end{array}$ \\
\hline Examinador(a): & $\begin{array}{l}\text { Assinatura: } \\
\text { Nome: ......... } \\
\text { Instituição: . }\end{array}$ \\
\hline Examinador(a): & $\begin{array}{l}\text { Assinatura: } \\
\text { Nome: ......... } \\
\text { Instituição: . }\end{array}$ \\
\hline Examinador(a): & $\begin{array}{l}\text { Assinatura: } \\
\text { Nome: ......... } \\
\text { Instituição: . }\end{array}$ \\
\hline Presidente: & $\begin{array}{l}\text { Assinatura: } \\
\text { Nome: ......... } \\
\text { Instituição: . }\end{array}$ \\
\hline
\end{tabular}




\section{AGRADECIMENTOS}

À Dra. Dolores Ursula Mehnert, por ter aceito os desafios que envolveram a realização desse projeto, por ter sonhado junto comigo, e pelos ensinamentos ao longo do caminho.

À Dra. Regina Pekelmann Marcus, por ter me aberto as portas à pesquisa científica.

À Dra. Sônia Maria Flores Gianesella, por ter me apresentado o fabuloso mundo dos vírus marinhos e, assim, dado origem a essa viagem.

Ao Dr. Curtis A. Suttle, pelos ensinamentos, oportunidades de aprendizagem e incondicional apoio antes e durante todos os anos do Doutorado.

À Dra. Hillândia Brandão da Cunha, por disponibilizar laboratório, embarcação, veículo e pessoal para a realização das coletas.

Ao Dr. Alex Krusche, pela logística das coletas.

Ao Dr. Paolo Marinho de Andrade Zanotto, pela valiosa parceria nas análises filogenéticas e de filodinâmica.

À Dra. Marli Ueda-Ito e a Dr. Jonas Kisielius, por viabilizarem as análises de microsocopia eletrônica de trasmissão.

A Jonismar Souza, pelas análises químicas das amostras de água.

À Dra. Flávia Saldaña-Corrêa, pela ajuda com as amostras de fitoplâncton.

À Bianca Vettorato, pela contagem, identificação e fotos do fitoplâncton.

À Dra. Patricia Garrafa, a Anthony Lopez e aos amigos Alice e Jonis, pela ajuda na coleta das amostras.

À Dra. Irma Nelly Gutierrez Rivera, pelas palavras de conforto e entusiasmo em momentos cruciais.

A Tiago, pela grande amizade e ajuda na revisão dessa tese.

À Telma, pelas conversas durante todo o percurso.

Às amigas Fernanda e Cris, pelas palavras de apoio e solidariedade, e pelas boas risadas durante esses seis anos.

Aos colegas André, Emma e Alex, pelos ensinamentos, ideias e fantásticos insights.

Aos amigos e colegas de laboratório, Jéssica, Caroline e Jérome, pela ajuda diária e pela companhia durante 2008.

À Fundação de Amparo à Pesquisa do Estado de São Paulo, pelo suporte financeiro e apoio à pesquisa.

À Coordenação de Aperfeiçoamento Pessoal de Nível Superior, pelo suporte financeiro.

Aos meus queridos Olívia, pai, e Bera, pelo carinho, confiança, reconhecimento, paciência e incentivo constantes. 
"Is there any hope?" "Oh yes," said Drop of Water.

"In the beginning was water and to water there is no end. Water is a child, holder of future, so let the child be. It's a question of balance, between abundance and scarcity, between use and abuse. A day will come soon, I hope, when I will be owned by none and shared by all, when I will be sullied by none and nourish all, when I will be taken freely and given freely.

In the beginning was water

and to water there is no end. Water is a child, holder of future, so let the child be.

A day will come soon, I hope, when we will start over, at peace with water, at peace with our future, one planet, one drop."

Extraído do poema "What the drop of water had to say", escrito por Yann Martel, para o evento

"Moving Stars and Earth for Water", organizado pela One Drop Foundation. 


\section{RESUMO}

Gimenes MV. Virioplâncton na Amazônia: estudo da diversidade dos vírus das famílias Phycodnaviridae e Myoviridae nos rios Negro, Solimões e Cuieiras [tese (Doutorado em Microbiologia)]. São Paulo: Instituto de Ciências Biomédicas da Universidade de São Paulo; 2010.

Os vírus são os agentes biológicos mais abundantes em ambientes aquáticos, podendo ser encontrados em concentrações de até $3 \times 10^{9}$ partículas por litro. Infectam, provavelmente, todos os organismos e micro-organismos aquáticos e estão presentes nos mais diversos sistemas, como, oceanos, rios, lagos, estromatólitos, recifes de corais, fumarolas submarinas, lagos hipersalinos, lagos alcalinos, fontes termais e gelo polar. Hoje se sabe que a comunidade viral - virioplâncton - é parte ativa e indispensável a ambientes aquáticos, tendo grande importância ecológica, uma vez que está envolvida em processos como ciclagem de nutrientes, diversificação e distribuição de algas e bactérias, controle de florações fitoplanctônicas, formação de nuvens e transferência gênica horizontal. Os objetivos deste projeto foram analisar as populações de ficodnavírus (Phycodnaviridae) e miofagos (Myoviridae) nos rios Cuieiras, Negro e Solimões, localizados na bacia Amazônica, próximo à região de Manaus, e determinar um possível impacto do lançamento de efluentes domésticos sobre essas populações. Para tanto, foram utilizadas as técnicas moleculares de $P C R$ (Polimerase Chain Reaction), DGGE (Denaturing Gradient Gel Electrophoresis), clonagem e sequenciamento, e microscopia eletrônica de transmissão (MET), além de análises filogenéticas e de filodinâmica, e levantamento da flora fitoplanctônica. A presença de ficodnavírus só foi constatada nas amostras dos rios Solimões e Cuieiras, $P C R$, mas não por MET, enquanto que miofagos foram detectados em todas as amostras dos rios Negro, Cuieiras e Solimões, por ambos os métodos. O perfil eletroforético da população de miofagos, resultante da $D G G E$, foi característico para cada rio, e mostrou-se constante nas amostras de um mesmo rio; a aplicação da técnica para análise dos ficodnavírus não foi possível. A partir das amostras de água coletadas, foram obtidos 104 clones de ficodnavírus e 180 de miofagos, cujas sequências foram utilizadas em estudos filogenéticos e de filodinâmica. Estes revelaram que os miofagos não se agrupam em função das características do ambiente nem da localidade, havendo uma relação mais próxima entre os clones ambientais do que com os fagos isolados. Com relação aos ficodnavírus, os resultados mostraram que os clones provenientes de ambientes de água doce são mais proximamente relacionados com os vírus marinhos $M p V, B p V$ e $O s V$, do que com o vírus $P B C V-1$, também de água doce, e que os clones ambientais agrupam-se em clados distintos dos de vírus isolados; os ficodnavírus não são panmíticos em relação ao ambiente que ocupam, havendo fluxo gênico entre os ambientes lótico e lêntico, e do marinho para os de água doce, mas não o contrário; houve variação no número de populações de ficodnavírus no último 1,5 milhão de anos, com um mínimo alcançado no período de 500 a 300 mil anos, seguido de recuperação até o presente. Contrariamente ao esperado, a interferência do lançamento de efluentes domésticos sobre as características da água e sobre as populações locais virais das famílias Phycodnaviridae e Myoviridae e fitoplanctônicas não foi observada, apesar de ter sido sugerida pela diminuição do número de táxons de fitoplâncton. 
Palavras-chave: Amazônia. DGGE. Filodinâmica. Myoviridae. Phycodnaviridae. 


\begin{abstract}
Gimenes MV. Virioplankton in the Amazon: diversity study of viruses from Phycodnaviridae and Myoviridae families in the Negro, Solimões and Cuieiras rivers [Ph.D. Thesis (Microbiology)]. São Paulo: Instituto de Ciências Biomédicas da Universidade de São Paulo; 2010.
\end{abstract}

Viruses are the most abundant agents in aquatic environments, found in concentrations up to $3 \times 10^{9}$ particles per liter. They infect a wide spectrum of organisms and microorganisms, and are present in a variety of aquatic systems such as, oceans, rivers, lakes, stromatolites, coral reefs, submarine fumaroles, hypersaline and alkaline lakes, thermal vents and polar ice. It is now known that the viral community (virioplankton) is an active and essential part of aquatic environments, being of great ecological importance since it is involved in processes such as nutrient cycling, diversification and distribution of algae and bacteria, phytoplankton bloom termination, cloud formation and horizontal gene transfer. The aims of this work were to analyse the populations of phycodnaviruses (Phycodnaviridae) and myophages (Myoviridae) in the Cuieiras, Negro and Solimões rivers, located in the Amazon Basin, close to the city of Manaus, and to determine a possible impact of sewage discharge in the Negro river on these populations. In order to accomplish that, PCR (Polimerase Chain Reaction), DGGE (Denaturing Gradient Gel Electrophoresis), cloning and sequencing, and Transmission Electron Microscopy (TEM) were used. Phylogenetics and phylodinamics analyses and a phytoplankton survey were also conducted. Phycodnaviruses were only detected in the samples from the Solimões and Cuieiras rivers, by PCR, but not by TEM, whereas myophages were detected in all samples from the Negro, Cuieiras and Solimões rivers by both PCR and MET. Myophages' DGGE fingerprints were unique for each river and constant in all samples from the same river; the use of DGGE fingerprinting for phycodnaviruses was not possible. A total of 104 and 180 clones of phycodnavirus and myophages were obtained, respectively, and these sequences were used in phylogenetic and phylodnamic analyses. Results showed that myopages do not cluster accordingly neither to the environment nor to the geographic location, and that environmental clones tend to cluster among themselves more than with isolated phages. Phycodnaviruses' phylogeny showed that freshwater clones are more closely related to the marine viruses $M p V, B p V$ and $O s V$ than to the freshwater virus $P B C V-1$, and that environmental clones cluster separately from isolated viruses. Results also showed that phycodnaviruses are not panmitic and that there is gene flux between riverine and lacustrine environments and also from marine to freshwater ones, but not the contrary. A fluctuation on the number of phycodnavirus' populations was observed in the last 1.5 million years, reaching the lowest values around 500 to 300 thousand years ago, followed by a recovery towards the present. Adversally to what was expected, the interference of sewage discharge on the water characteristics and the local viral (phycodnavirus and myophage) and phytoplanktonic populations was not detected, even though indicated by the decrease of phytoplankton taxa.

Keywords: Amazon. DGGE. Phylodinamics. Myoviridae. Phycodnaviridae. 


\section{LISTA DE ABREVITURAS E SIGLAS}

$B p V$ : vírus de Bathycoccus

CbV: vírus de Chrysochromulina brevifilum

CODA: carbono orgânico dissolvido alóctone

CODC: carbono orgânico dissolvido cromofórico

CONAMA: Conselho Nacional do Meio Ambiente

CsfrRNAV: vírus RNA de Chaetoceros socialis Lauder f. radians

CsNIV e CspNIV: vírus de inclusão nuclear de Chaetoceros salsugineum

CtenRNAV: vírus RNA de Chaetoceros tenuissimus

DBO: Demanda bioquímica de oxigênio

DGGE: Denaturing Gradient Gel Electrophoresis

DMS: dimetilsulfeto

DMSP: dimetilsulfoniopropionato

DNA: ácido desoxirribonucleico

EhV: vírus de Emiliania huxleyi

EsV: vírus de Ectocarpus siliculousus

HaV: vírus de Heterosigma akashiwo

HPD: highest posterior density

ICTVdB: The Universal Virus Database of teh International Committee on Taxonomy of Viruses
INPA: Instituto Nacional de Pesquisa da Amazônia

$\mathrm{Kb}$ : kilo pares de base

MCMC: Monte Carlo via cadeia de Markov

MET: Microscopia eletrônica de transmissão

MOD: matéria orgânica dissolvida

MOP: matéria orgânica particulada

$M p V$ : vírus de Micromonas pusilla

MV: máxima verossimilhança

NCLDV: nucleocytoplasmic large DNA viruses

OD: Oxigênio dissolvido

OsV: vírus de Ostreococcus

$\mathrm{pb}$ : pares de base

$P B C V$ : vírus Chlorella de Paramecium bursaria

PCR: Polimerase Chain Reaction

$P g V$ : vírus de Phaeocystis globosa

$P V D F$ : fluoreto de polivinilideno

RE: retículo endoplasmático

$R N A$ : ácido ribonucleico

RsRNAV: vírus RNA de Rhizosolenia setigera

$\mathrm{SH}$ : substância húmica

Tm: melting temperature

TMRCA: tempo do ancestral comum mais recente

USP: Universidade de São Paulo

UV: ultra violeta 
1 INTRODUÇÃO

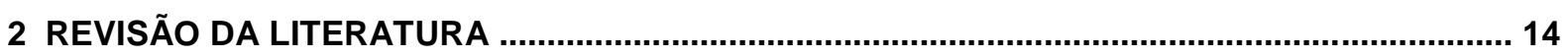

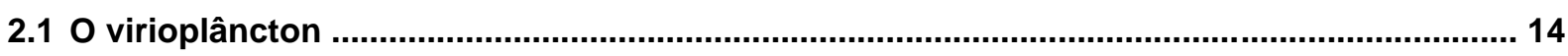

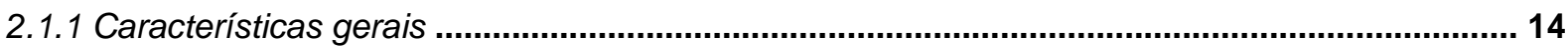

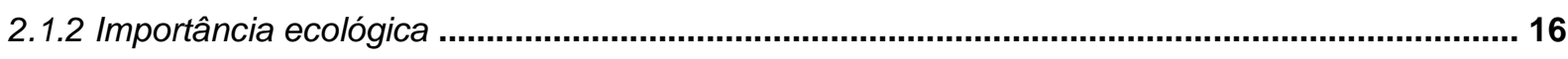

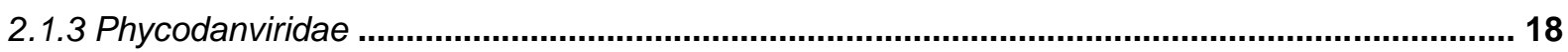

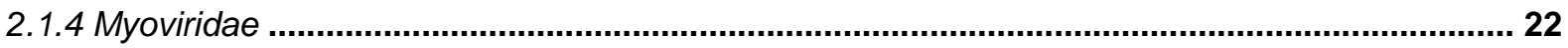

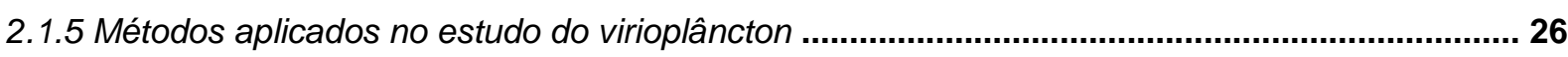

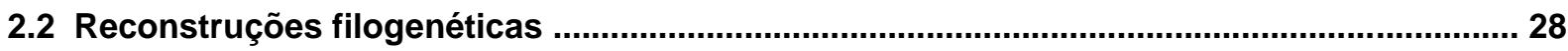

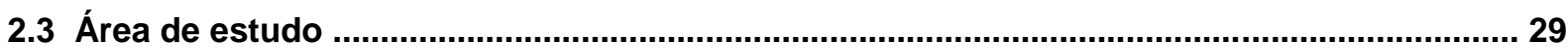

2.4 Importância limnológica de parâmetros físicos, químicos e biológicos ............................ 30

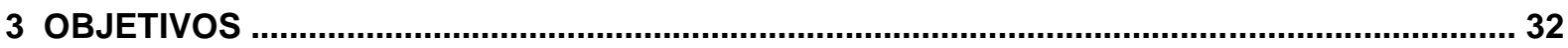

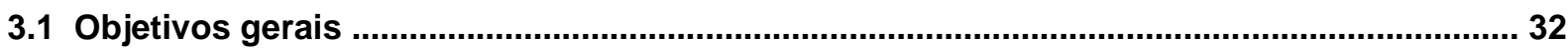

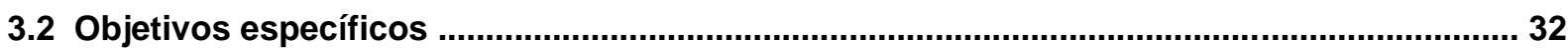

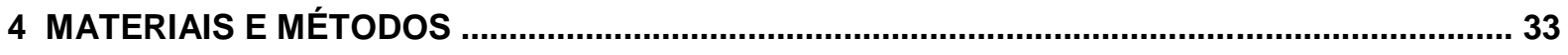

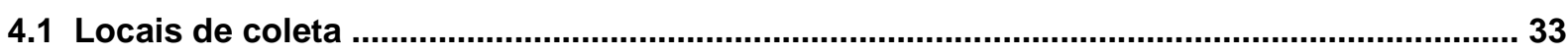

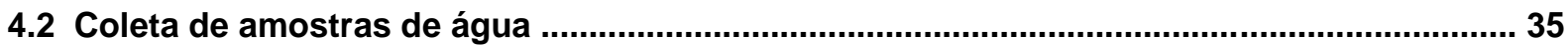

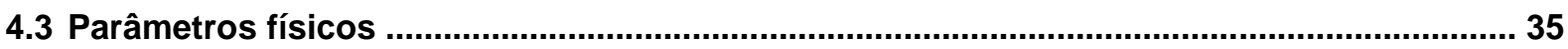

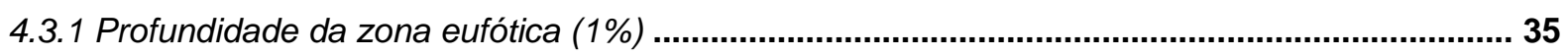

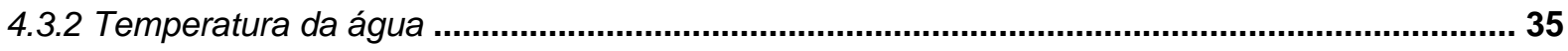

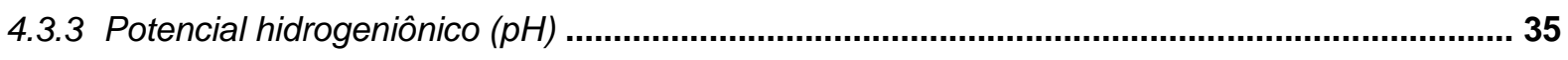

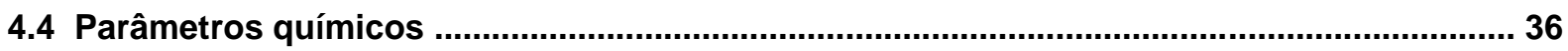

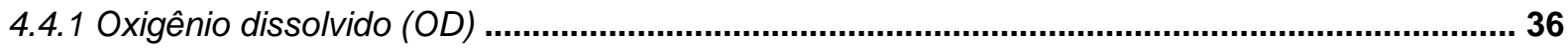

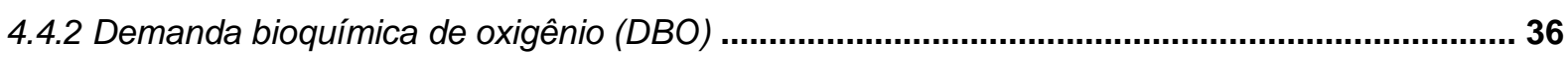

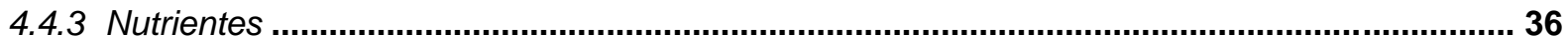

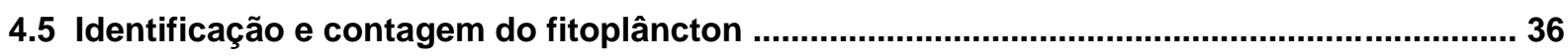

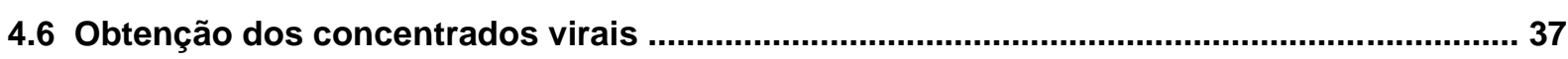

4.7 Cálculo da eficiência da concentração ……........................................................................ 38

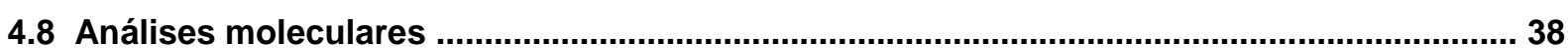

4.8.1 Purificação das amostras de água - Tratamento com Vertre ${ }^{\circledR}$............................................... 38

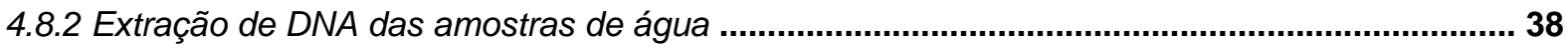

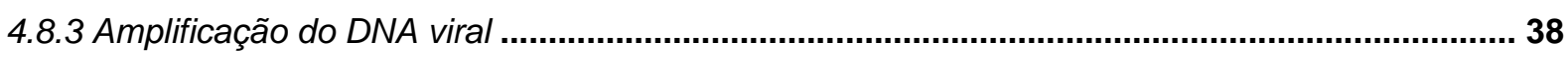

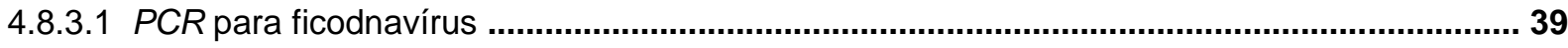

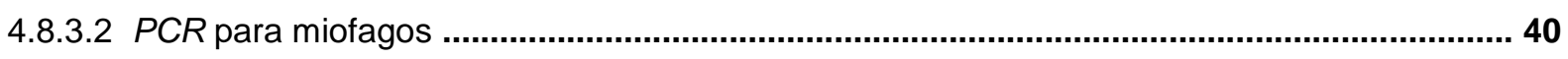

4.8.4 Eliminação das células bacterianas por filtração .................................................................41 4

4.8.5 Análise da estrutura das comunidades virais por DGGE (Denaturing Gradient Gel

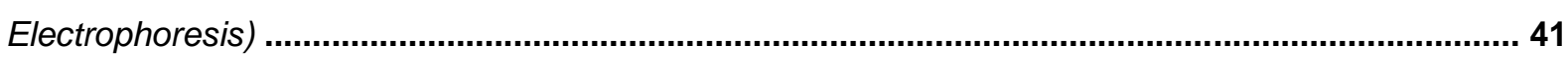

4.8.6 Construção de biblioteca gênica a partir dos fragmentos do gel de DGGE .............................. 42 


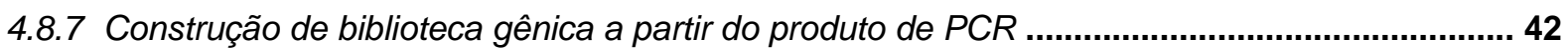

4.8.8 Verificação da eficiência de clonagem .................................................................................... 42

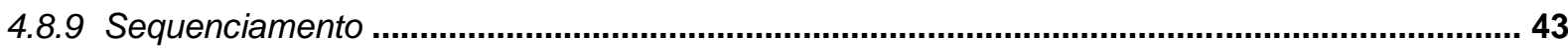

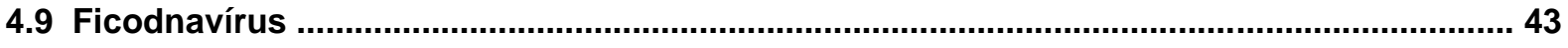

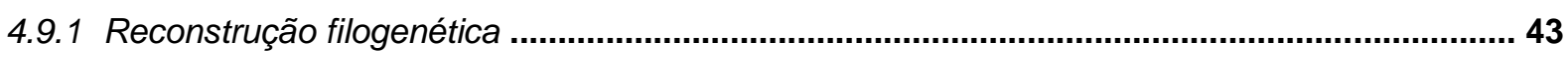

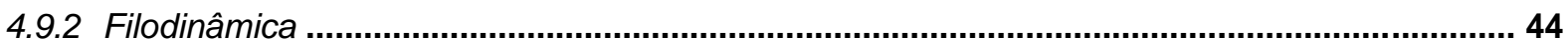

4.9.3 Migração de ficodnavírus entre ambientes aquáticos .......................................................... 45

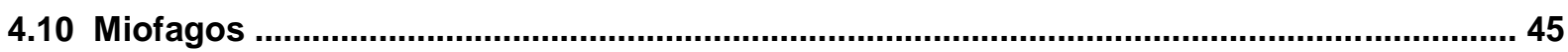

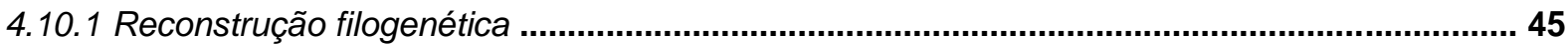

4.11 Análise da morfologia viral por Microscopia Eletrônica de Transmissão (MET) ............... 45

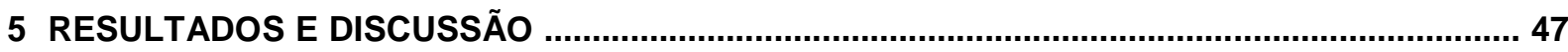

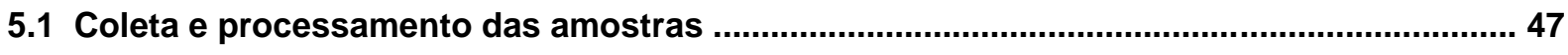

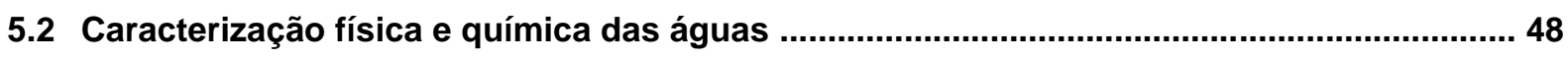

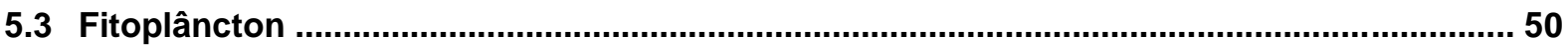

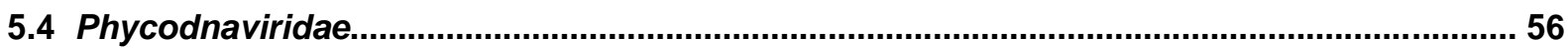

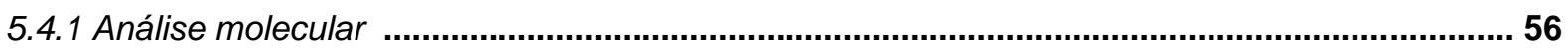

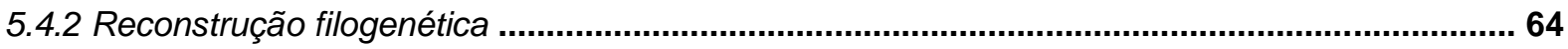

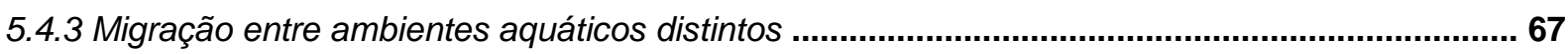

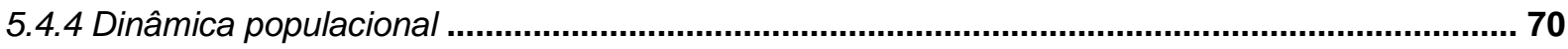

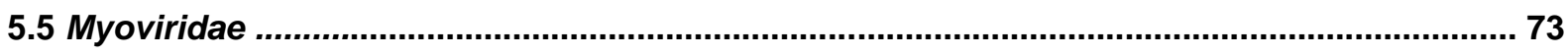

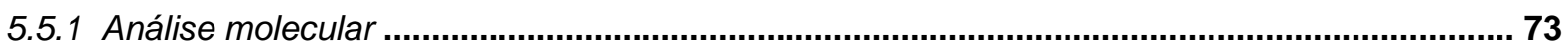

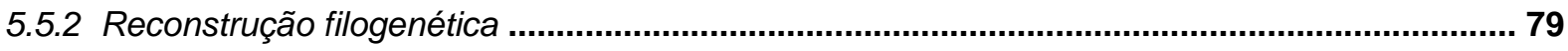

5.6 Detecção visual e caracterização morfológica de partículas virais ..................................... 81

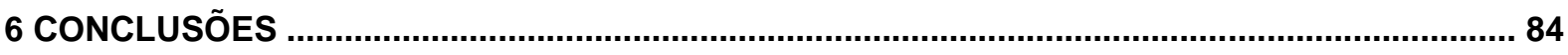

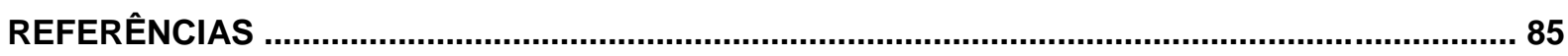

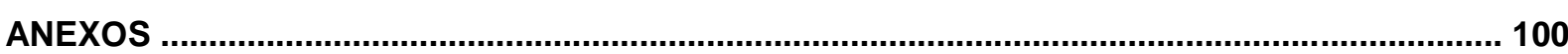

ANEXO A - Mapa parcial do genoma do vírus $P B C V-1$, com indicação dos genes transcritos da direita para a esquerda e $(L, \leftarrow)$ e da esquerda para a direita $(R, \rightarrow)$. Genes com funções semelhantes ou relacionadas estão identificados pela mesma cor. Gene DNA pol indicado pela seta $(\rightarrow)$

ANEXO B - Mapa funcional do genoma do fago T4 com marcação do gene gp23 ( $\square$ ) ............ 102

ANEXO C - Sequências de clones ambientais usadas na reconstrução filogenética dos

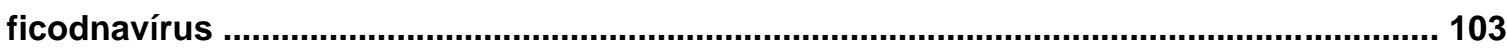

ANEXO D - Isolados da família Phycodnaviridae usados na reconstrução filogenética dos

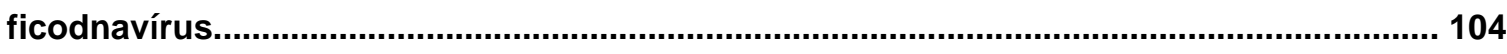

ANEXO E - Sequências de clones ambientais usadas na reconstrução filogenética dos miofagos 107

ANEXO F - Isolados da família Myoviridae usados na reconstrução filogenética dos miofagos 
ANEXO G - Identidade das sequências obtidas a partir de clones contendo DNA amplificado com os oligonucleotídeos AVS-1 e AVS-2 (supostamente ficodnavírus), comparadas com as sequências do GenBank através de análise com o blast (non-redundant) - nucleotídeo 109

ANEXO H - Identidade das sequências obtidas a partir de clones contendo DNA amplificado com os oligonucleotídeos AVS-1 e AVS-2 (supostamente ficodnavírus), comparadas com as sequências do GenBank através de análise com o tblastx (non-redundant) -

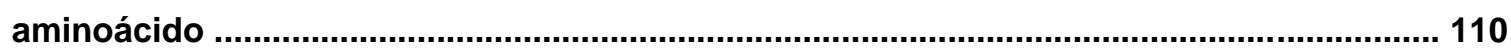

ANEXO I - Alinhamento múltiplo das sequências de miofagos ............................................... 111 


\section{INTRODUÇÃO}

"What is a scientist after all?

It is a curious man looking through a keyhole, the keyhole of nature, trying to know what's going on."

(Jacques Cousteau)

A história e a atividade da vida na Terra têm sido guiadas pela presença e ação de microorganismos, uma vez que eles foram e continuam sendo agentes indispensáveis na evolução climática, geológica, geoquímica e biológica do planeta. Por muitos anos, estudos ecológicos sobre a comunidade microbiológica aquática estiveram restritos à pesquisa de bactérias. A descoberta da existência de grande número de partículas virais (virioplâncton) em ambientes pelágicos marinhos, em 1979 (Torrella e Morita, 1979), entretanto, marcou o início de um novo campo de pesquisa, que vem se expandindo rapidamente nos últimos 15 anos, principalmente após o reconhecimento da importância dos vírus aquáticos, em 1983, por Azam et al.

Não há dúvidas de que os vírus sejam parte ativa e de grande importância em ecossistemas aquáticos. Em ambientes marinhos, essa comunidade tem sido estudada nas diversas latitudes, do Ártico (Steward et al., 1996) à Antártica (Steward et al., 1992), passando pelos Oceanos Atlântico e Pacífico, em ambas as porções temperada e tropical (Bergh et al., 1989; Cochlan et al., 1993; Wilhelm et al., 2003). Tais estudos têm focalizado não somente a zona fótica da coluna d'água, mas também o sedimento (Hewson et al., 2001; Danovaro et al., 2008), fumarolas submarinas (Ortmann e Suttle, 2005), wetlands (Jackson e Jackson, 2008), recifes de corais (Patten et al., 2006; Davy e Patten, 2007; Patten et al., 2008) e estromatólitos (Desnues et al., 2008).

Apesar de o mesmo não ocorrer para ambientes de água doce, onde um número significativamente menor de estudos tem sido conduzido somente em ambientes lacustres do hemisfério norte (Colombet et al., 2006; Lymer et al., 2008a; Lymer et al., 2008b; Tijdens et al., 2008a; Clasen e Suttle, 2009), na Antártica (Madan et al., 2005; Vanucci et al., 2005; Säwström et al., 2007), e em alguns rios europeus e norte-americanos (Leroy et al., 2008; Peduzzi e Luef, 2008; Short e Short, 2008), sabe-se, hoje, que o conhecimento referente a ambientes marinhos estende-se aos de água doce. Além de a importância dos vírus na cadeia alimentar microbiana já ter sido verificada em ambos os ambientes, a abundância do virioplâncton, o tamanho da progênie viral, assim como taxa de produção e porcentagem de células infectadas, também parecem ser independentes da salinidade, mas relacionadas ao estado trófico do ambiente e às variações sazonais. Apesar de o papel dos vírus nos ambientes aquáticos ser bastante complexo e ainda permanecerem muitas questões em aberto, a literatura disponível indica que, apesar de haverem algumas diferenças, muitos dos controles sobre a atividade e a diversidade do virioplâncton são similares em ambientes marinhos e de água doce (Wilhelm e Matteson, 2008), o que nos permitiu caracterizar o grupo com base em dados provenientes de ambos os ambientes. 
Em âmbito nacional, a totalidade dos estudos realizados na área da virologia "ambiental", até o presente momento, enfoca apenas aspectos de Saúde Pública e agentes causadores de doenças (Santos et al., 2004; De Paula et al., 2007; Miagostovich et al., 2008; Ferreira et al., 2009). Em adição à ausência de estudos brasileiros sobre a ecologia de vírus aquáticos verdadeiramente ambientais (autóctones), a importância da região amazônica, principalmente em termos de biodiversidade, a riqueza de ambientes da região e a importância ecológica do virioplâncton justificaram a realização do presente estudo, juntamente com a necessidade de se conhecer melhor esses vírus e seus papéis, na busca por uma compreensão mais abrangente da ecologia dos ambientes aquáticos e das famílias virais envolvidas. 


\section{REVISÃO DA LITERATURA}

\subsection{O Virioplâncton}

\subsubsection{Características gerais}

O virioplâncton abrange partículas de $0,02 \mu \mathrm{m}$ a $0,2 \mu \mathrm{m}$ de diâmetro, presentes em concentrações entre $\sim 3 \times 10^{6}$ vírus. $\mathrm{mL}^{-1}$ em oceano profundo (Guixa-Boixereu et al., 2002; Ortmann e Suttle, 2005) e $\sim 10^{8}$ vírus. $\mathrm{mL}^{-1}$ em regiões costeiras do Pacífico, altamente produtivas (Clasen et al., 2008). Assumindo uma concentração média de $3 \times 10^{9}$ vírus. $L^{-1}$, os aproximados $1,3 \times 10^{18} \mathrm{~m}^{3}$ ocupados pelos oceanos da Terra hospedam cerca de $4 \times 10^{30}$ partículas virais. Similarmente, os 0,2 $\mathrm{fg}$ de carbono de cada vírion totalizam $200 \mathrm{Mt}$ de carbono, quantidade equivalente a aproximadamente 75 milhões de baleias azuis; e isso sem contar a quantidade de vírus presente nos sistemas aquáticos terrestres.

Assim, a fração viral é, além do mais diverso, o mais abundante componente do plâncton, e o segundo maior em termos de biomassa, só perdendo para os organismos procariotos. Ainda, cabe ressaltar que dados indicam que mais de $50 \%$ dos $4 \times 10^{30}$ vírions presentes nos oceanos são infectivos (Wilhelm et al., 1998b).

Esses agentes infectam grande variedade de bactérias heterotróficas (Borsheim, 1993), cianobactérias (Suttle e Chan, 1993), algas eucarióticas (Cottrel e Suttle 1991; Suttle e Chan, 1995), nanoflagelados heterotróficos (Garza e Suttle, 1995) e arquéias (Zillig et al., 1996), além de outros animais marinhos, de crustáceos a baleias. Dentre os diversos grupos virais já encontrados em amostras ambientais de água, estão duas famílias ecologicamente importantes - Phycodnaviridae e Myoviridae, as quais foram escolhidas como alvo deste estudo.

Considerando a necessidade do metabolismo celular para a multiplicação viral, verifica-se que a produção e a distribuição de vírions em ambientes aquáticos são determinadas por fatores que afetam a produtividade e a densidade das populações hospedeiras (Heldal e Bratbak, 1991; Maranger e Bird, 1995). Dessa forma, conclui-se que um fator que interfere na dinâmica do virioplâncton é a profundidade.

A transparência da água nos diversos ambientes varia de alguns centímetros em lagoas eutrofizadas a dezenas de metros em regiões oceânicas oligotróficas, dependendo da composição da água e da produtividade do ambiente. A região da coluna d'água denominada zona eufótica corresponde ao intervalo da coluna entre a superfície e a profundidade, onde a intensidade da radiação solar equivale a $1 \%$ daquela que atinge a superfície.

$\mathrm{Na}$ zona eufótica de ambientes marinhos, a intensidade e o comprimento da luz ditam padrões específicos de distribuição dos seres fotoautotróficos (Olson et al., 1990a; Olson et al., 
1990b). No mesmo sentido, a temperatura da água e os gradientes de salinidade podem resultar na estratificação da coluna d'água com o estabelecimento das termo e haloclinas, que propiciam a ocorrência de ambientes físico-químicos distintos, os quais também determinam padrões de distribuição do fitoplâncton. Com a estratificação da coluna d'água, há um aumento na concentração de nutrientes, bactério e fitoplâncton, na região da termoclina (Mitchell et al., 1985), fato também observado na concentração de partículas virais (Weinbauer et al.,1995).

Outro fator que influencia o virioplâncton é a sazonalidade. A variação temporal na abundância do grupo vem sendo estudada e descrita desde os primeiros trabalhos de Bergh et al. (1989) em ambiente marinho, e, mais recentemente, em ambientes de água doce (Tijdens et al., 2008a; Tijdens et al., 2008b; Filippini et al., 2008; Lymer et al., 2008b).

Sendo a produção de partículas virais em ambientes aquáticos constante e ocorrendo em altas taxas (Noble e Fuhrman, 2000; Wilhelm et al., 2002), pode-se pensar que existem mecanismos que controlem a abundância do virioplâncton, mantendo essas populações em equilíbrio. Nesse sentido, existem dois processos distintos descritos: a inativação e a destruição das partículas virais.

A forma mais efetiva de destruição dos vírions é por meio de sua predação por flagelados heterotróficos, também ocorrendo naturalmente depois de determinado tempo (Gonzalez e Suttle, 1993). Já, a inativação das partículas virais tem como principal causa a radiação ultravioleta, principalmente UV-B (Suttle e Chen, 1992; Wilhelm et al., 1998a), com taxa de inativação diversa nos diferentes estudos, variando de $40 \%$ hora $^{-1}$ a $80 \%$ hora $^{-1}$ (Suttle e Chen, 1992; Wilhelm et al., 1998a) ou de 5 10\%.hora ${ }^{-1}$ a $10 \%$.hora $^{-1}$ (Fuhrman e Suttle, 1993; Noble e Fuhrman, 1997; Wommack et al., 1996). Em contrapartida, outros estudos mostram que bactérias hospedeiras têm a capacidade de reparar o DNA viral lesado, sob radiação ultravioleta, tornando os vírus novamente infecciosos. Assim, a fotorreativação é responsável por manter a população viral infectiva, apesar das altas taxas de danificação do DNA ocasionadas pela radiação UV (Weinbauer et al., 1997; Wilhelm et al., 1998b).

Existe ainda outra forma de inativação viral, pela ação de enzimas hidrolíticas e de colóides termossensíveis presentes na água (Noble e Fuhrman, 1997; Suttle e Chen, 1992). Entretanto o mecanismo pelo qual a atividade virucida se dá permanece desconhecido.

A adsorção de vírions às células e à matéria particulada é também uma maneira eficiente de remoção das partículas virais da zona eufótica, uma vez que, com o aumento da densidade, a partícula viral adsordida afunda (Bitton e Mitchell, 1974; Proctor e Fuhrman, 1991). Esse processo livra o fitoplâncton do ataque viral e faz da interface água - sedimento o local de maior concentração viral da coluna d'água dos oceanos. Assim, os sedimentos marinhos são conhecidamente grandes reservatórios de vírus aquáticos, que podem permanecer infecciosos por muitas décadas (Lawrence et al., 2002; Suttle, 2000). 


\subsubsection{Importância ecológica}

Hoje se sabe que a comunidade viral é parte ativa e indispensável a ambientes aquáticos e está envolvida em processos como ciclagem de nutrientes (Fuhrman, 1999; Wilhelm e Suttle, 1999), diversificação e distribuição de algas e bactérias (Van Hannen et al., 1999), controle de florações fitoplanctônicas (Castberg et al., 2001), formação de nuvens (Malin et al., 1998) e transferência gênica horizontal (Ripp et al., 1994; Chiura, 1997; Jiang e Paul, 1998).

Sendo o virioplâncton responsável pela morte de uma parcela significativa do bactério e do fitoplâncton (principalmente durante florações), ele exerce também influência direta sobre os ciclos geoquímicos marinhos. Através do ciclo lítico, o vírus converte células em vírions e debris celulares (matéria orgânica dissolvida e particulada - colóides e fragmentos celulares) que se tornam imediatamente disponíveis à comunidade bacteriana, agindo, portanto, como catalisador na transformação de nutrientes da forma particulada para a dissolvida (Bratbak et al., 1990; Proctor e Fuhrman, 1990; Fuhrman, 1992) (Figura 1).

Dessa forma, a atividade viral resulta na retenção de nutrientes na zona eufótica e no sequestro do carbono (fixado como biomassa fito e bacterioplanctônica), que seria dos consumidores do merozooplâncton e, consequentemente, dos níveis tróficos seguintes (Furhman, 1992; Bratbak et al., 1994; Murray e Eldridge, 1994; Thingstad e Lignell, 1997).

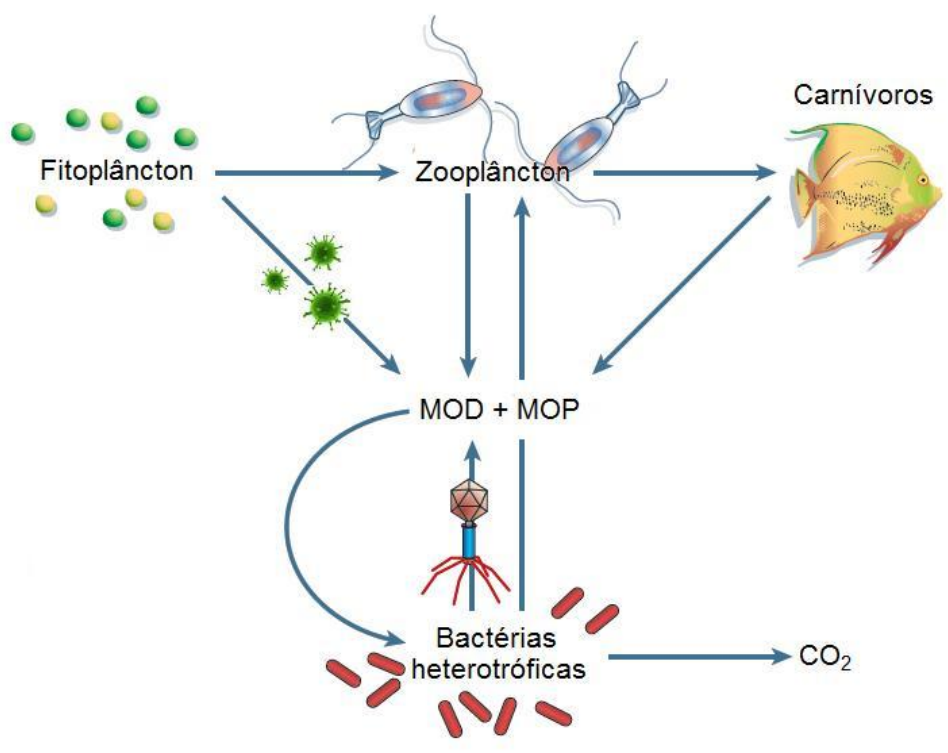

Figura 1. Influência dos vírus na alça microbiológica. Fonte: modificado de Suttle (2005). 
Além da alteração no ciclo do carbono e do nitrogênio nos ambientes marinhos, a lise viral de células fitoplanctônicas também interfere no ciclo de outro elemento - o fósforo; isso porque ela resulta na liberação de dimetilsulfoniopropionato (DMSP) intracelular. Quando esse processo ocorre durante florações, o virioplâncton está, potencialmente, influenciando o clima global, posto que o DMSP liberado com a lise celular é a molécula precursora do gás dimetilsulfeto (DMS), o qual influencia na formação de nuvens (Brussaard et al., 1996; Malin et al., 1998).

Outro aspecto que evidencia a importância ecológica dos vírus aquáticos é a influência que esses agentes exercem sobre as composições específicas das comunidades aquáticas. Mesmo sendo responsável por pequena parcela da mortalidade de um grupo de organismos, sua atividade tem profundo efeito na proporção relativa entre as diferentes espécies ou linhagens da comunidade (Waterbury e Valois, 1993; Cochran e Paul, 1998).

Acredita-se que a infecção viral seja, além de espécie-específica, dependente da densidade da população hospedeira. Levando em consideração que vírus aquáticos precisam se difundir ao acaso de hospedeiro a hospedeiro, hospedeiros raros são menos suscetíveis à infecção viral. À semelhança, quando uma espécie em particular começa a ficar mais abundante, passa a ser mais suscetível a infecções virais. Esses fatos podem ter grande relevância na tentativa de esclarecer 0 paradoxo apresentado por Hutchinson (1961), há 35 anos, que questionava a coexistência de tantos tipos diferentes de fitoplâncton (e bacterioplâncton) competindo pelos mesmos recursos, quando, teoricamente, deveria haver apenas algumas espécies dominantes.

Baseado nessas observações, Thingstad (2000) propôs a teoria Kill the winner, a qual sugere que a presença de uma espécie hospedeira preponderante é seguida de um aumento proporcional da população de vírus que a infecta, ocasionando um aumento nas infecções virais e consequente morte celular. Assim, o virioplâncton, além de controlar a abundância da população pela diminuição do número de indivíduos, disponibiliza recursos que propiciam o desenvolvimento e a multiplicação das outras espécies hospedeiras (Figura 2).

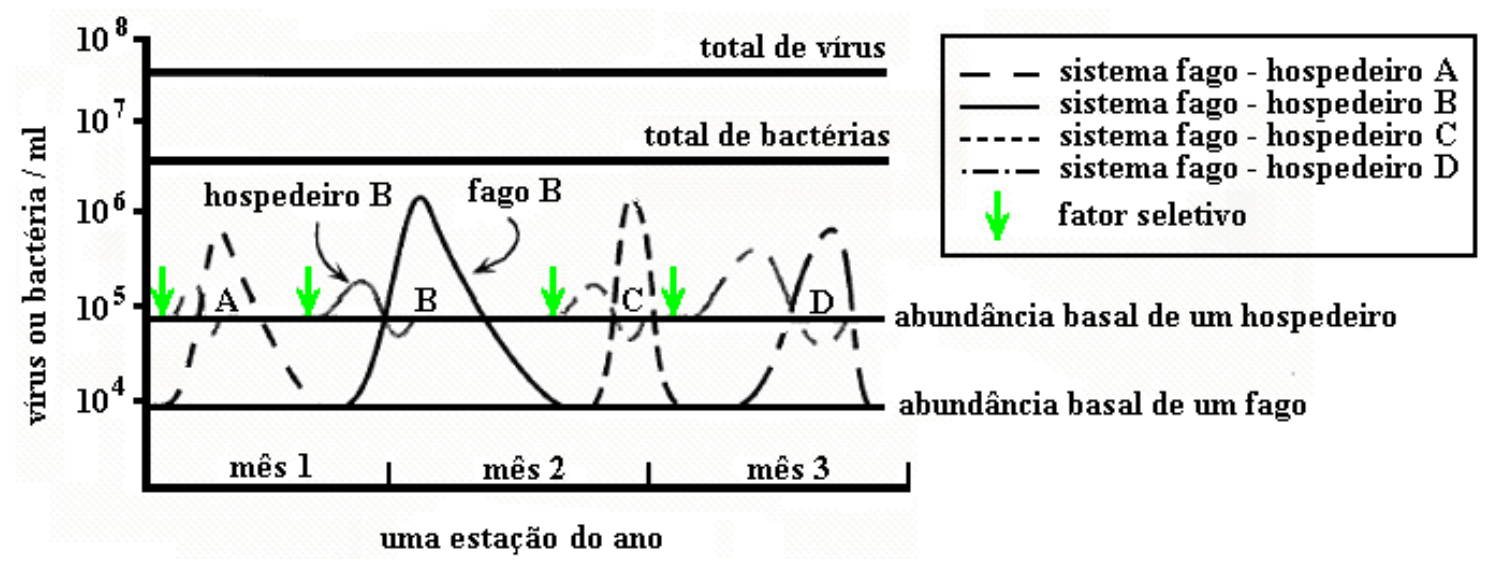

Figura 2. Modelo do controle exercido pelo virioplâncton sobre a diversidade da comunidade de hospedeiros. Fonte: Wommack e Colwell (2000). 
O desenvolvimento de resistência à infecção viral por hospedeiros é fato conhecido. No ambiente marinho, estudos mostram que membros do bacterioplâncton (cianobactérias) são altamente resistentes à infecção por fagos presentes no mesmo ambiente (Waterbury e Valois, 1993; Suttle e Chan, 1995), onde, mesmo com a predominância de hospedeiros resistentes, uma pequena população de hospedeiros suscetíveis ( $>0,001 \%$ da abundância total de hospedeiros) e de fagos virulentos sobrevive (Chao et al., 1977; Levin et al., 1977; Lenski e Levin, 1985; Lenski, 1988). Uma possível explicação para esse comportamento paradoxal reside no fato de a resistência representar um custo fisiológico à célula; assim, hospedeiros suscetíveis apresentam vantagem energética e de crescimento sobre hospedeiros resistentes (Chao et al., 1977; Gill e Nealson, 1972; Spanakis e Horne, 1987).

O aspecto mais desconhecido sobre ecologia de vírus marinhos é o seu papel na troca genética entre micro-organismos, na evolução e na genética de populações. A transmissão de $D N A$ de um hospedeiro a outro, via infecção viral, tanto em ambiente marinho (Jiang e Paul, 1998) como de água doce, (Ripp et al., 1994), já foi constatada. Esse processo, em larga escala de tempo e espaço, teria como efeito a homogeneização genética nas populações de hospedeiros suscetíveis a infecções virais. Apesar de a maioria dos estudos relatar que este processo se dá somente no grupo restrito de hospedeiros suscetíveis, Chiura (1997) mostrou o caso de bacteriófagos marinhos capazes de realizar transferência genética horizontal não específica, levantando a questão de que a amplitude das consequências da transferência horizontal de genes realizada pelos vírus pode estar sendo subestimada.

O reconhecimento da grande importância do virioplâncton na dinâmica dos ambientes aquáticos foi responsável por desencadear significativa mudança no entendimento sobre o funcionamento desses ambientes, abrangendo desde processos microbianos de micro escala até processos biogeoquímicos globais (Wommack e Colwell, 2000; Weinbauer, 2004; Suttle, 2007).

\subsubsection{Phycodnaviridae}

A família Phycodnaviridae abrange vírus líticos e lisogênicos que, por possuírem grandes genomas (de $160 \mathrm{~Kb}$ a $560 \mathrm{~Kb}$ ), fazem parte do grupo dos NCLDV (nucleocytoplasmic large DNA viruses), o qual inclui as famílias Poxviridae, Iridoviridae, Asfarviridae, Phycodnaviridae e Mimiviridae. Os ficodnavírus estão distribuídos em seis gêneros - Chlorovirus, Prasinovirus, Prymnesiovirus, Phaeovirus, Coccolithovirus e Raphidovirus, baseados, inicialmente, no organismo hospedeiro e, posteriormente, confirmados por estudos das sequências gênicas (Van Etten et al., 2002; Dunigan et al., 2006). Apesar da grande variedade de hospedeiros, os ficodnavírus possuem uma morfologia estrutural similar, fato consistente com a existência de um ancestral comum, independentemente da informação genômica de cada vírus; os vírions medem de $100 \mathrm{~nm}$ a $220 \mathrm{~nm}$ de diâmetro e apresentam o core de DNA dupla fita e proteínas, envolto em uma bicamada lipídica, e um capsídeo 
icosaédrico, formado por 20 faces triangulares equiláteras, compostas por subunidades proteicas (Figura 3) (Wilson et al., 2009).

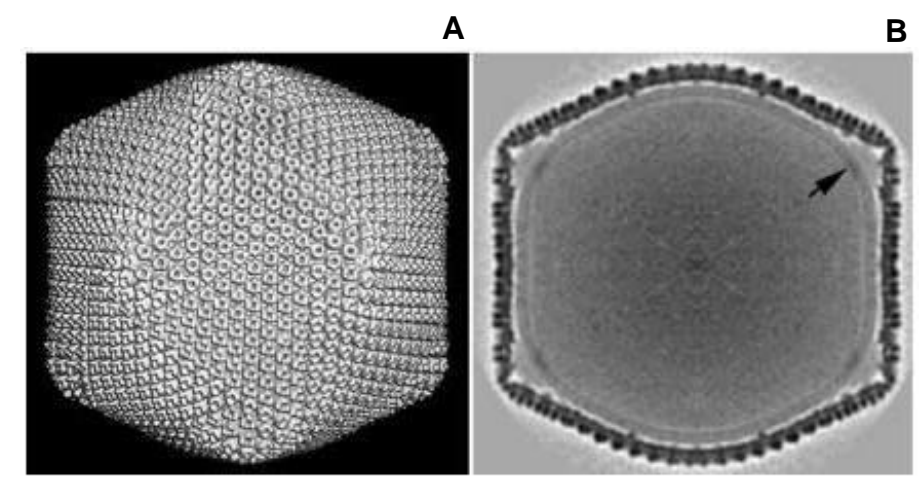

Figura 3. Em A, reconstrução tridimensional do $P B C V-1$ a partir de micrografias eletrônicas. Em $\mathrm{B}$, sessão transversal de uma reconstrução tridimensional, na qual a membrana interna do vírus é indicada pela seta.

Fonte: Van Etten et al. (2002).

O protótipo do grupo é o vírus PBCV-1 (vírus Chlorella de Paramecium bursaria), do gênero Chlorovirus, que infecta algas verdes unicelulares do gênero Chlorella, as quais são simbiontes de paramécios da espécie $P$. bursaria (Van Etten et al., 2002). O genoma do PBCV-1 (ANEXO A) possui $330 \mathrm{~Kb}$, que codificam cerca de 11 RNA transportadores e 375 proteínas, das quais aproximadamente metade tem função conhecida. A replicação do DNA envolve pelo menos dez proteínas, incluindo a $D N A$ polimerase da família $\mathrm{B}$, que possui, além do domínio responsável pela função polimerase, um domínio de exonuclease proof-reading 3'-5' (Kang et al., 2005), e é o alvo deste estudo. Os vírions do PBCV-1 pesam aproximadamente $1 \times 10^{9} \mathrm{Da}$ e contêm mais de 100 proteínas diferentes; só a Vp54 (major capsid protein) representa cerca de $40 \%$ do total das proteínas virais.

O PBCV-1 é um vírus lítico, cujo ciclo tem duração de seis a oito horas, da infecção à lise celular (Figura 4), liberando aproximadamente mil partículas, das quais cerca de 30\% são infecciosas (Wilson et al., 2009). Em suma, a infecção se inicia com a rápida adsorção do vírus à parede celular da célula hospedeira, provavelmente através de um único vértice, seguida da degradação da parede celular por uma enzima viral. A fusão da membrana interna viral com a membrana celular resulta na entrada do $D N A$ e das proteínas virais na célula, sendo o gatilho para uma rápida despolarização da membrana celular, provavelmente responsável por evitar a infecção celular por outros vírus. Em cerca de cinco a dez minutos após a infecção celular, o DNA viral, juntamente com as proteínas a ele associadas, migram para o núcleo, onde ocorre a transcrição dos genes precoces; ao mesmo tempo, - DNA cromossomal do hospedeiro começa a ser degradado, momento no qual a célula é reprogramada para transcrever apenas $R N A$ s virais. A replicação do $D N A$ viral se inicia entre 60 e 90 minutos após a infecção, e é seguida da transcrição dos genes tardios. Entre duas e três horas após 
a infecção, inicia-se a formação dos novos capsídeos no citoplasma, o qual se enche de partículas virais infecciosas em até três horas, culminando na lise celular (Figura 5).

A

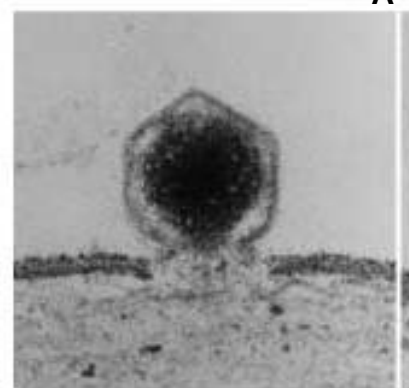

B

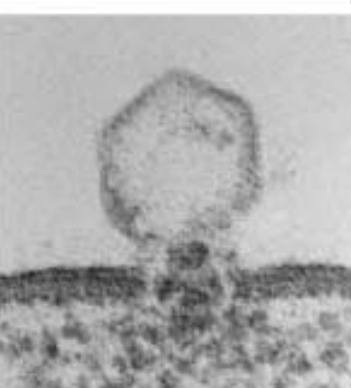

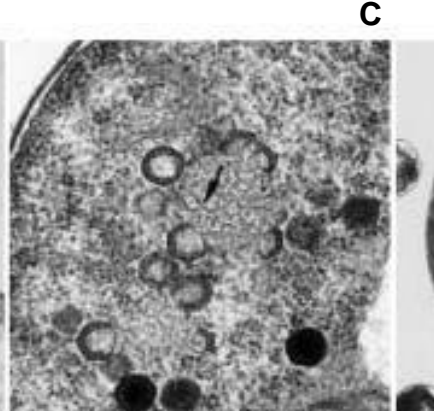

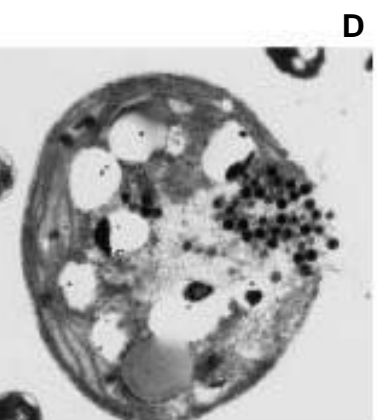

Figura 4. Infecção de alga Chlorella NC64A pelo PBCV-1. (A) Digestão da parede celular após adsorção do vírus; (B) Entrada do conteúdo viral na célula; (C) Formação das novas partículas virais; (D) Lise celular Fonte: Van Etten et al. (2002).

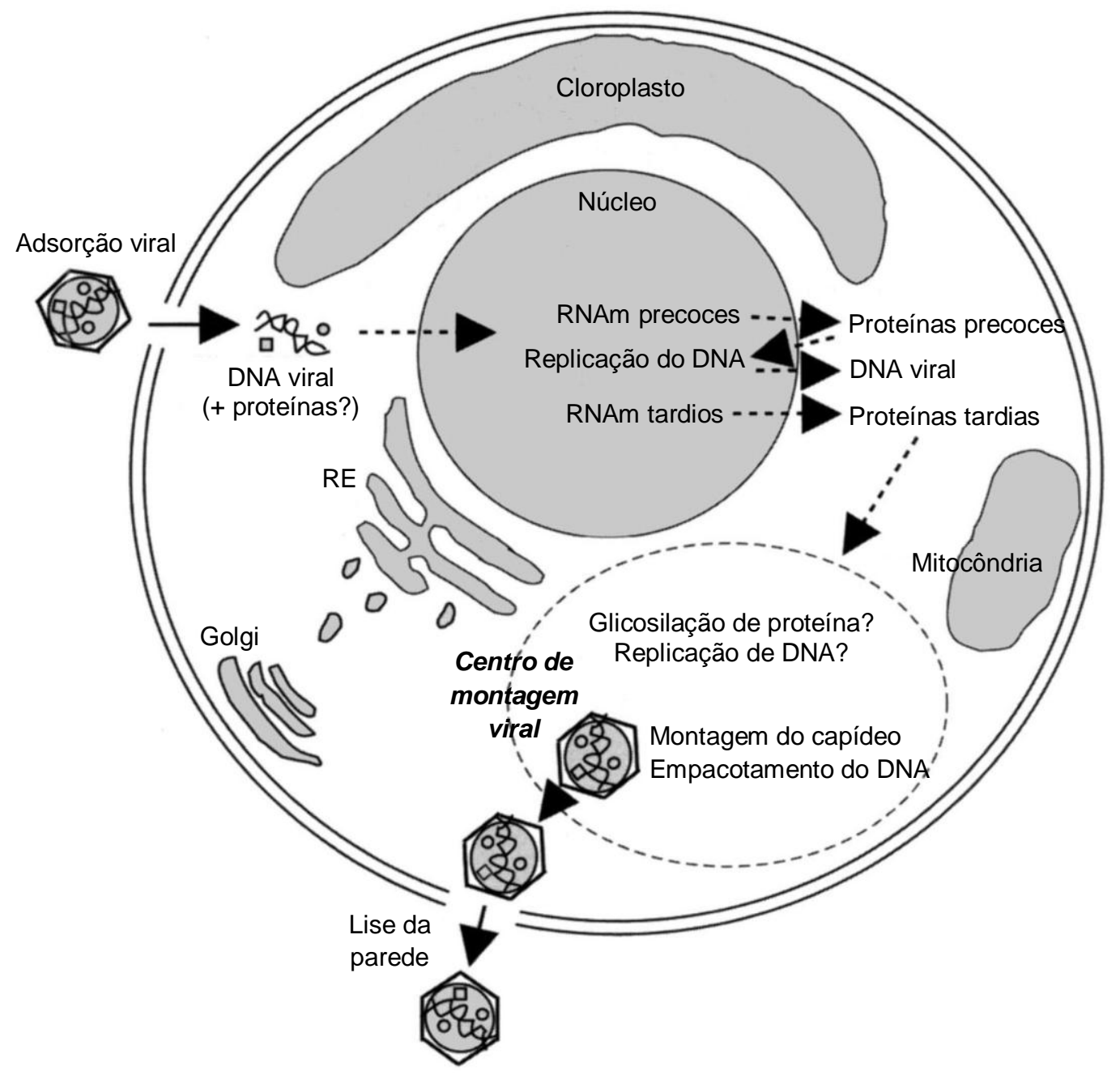

Figura 5. Ciclo de replicação do PBCV-1, mostrando eventos conhecidos ( $\longrightarrow$ ) e hipotéticos $(--\rightarrow)$ ). Fonte: Wilson et al. (2009). 
A estratégia de replicação adotada pelo $P B C V$-1, no entanto, não é única entre os ficodnavírus. Os faeovírus (ex. vírus de Ectocarpus siliculousus - EsV-1), por exemplo, são lisogênicos e infectam somente os gametas das algas hospedeiras (Ectocarpus siliculousus), os quais não possuem parede celular, dispensando assim um "maquinário" necessário aos clorovírus. Depois da adsorção viral à célula, DNA e proteínas virais são liberados no citoplasma e, cerca de cinco minutos após a infecção, já estão no núcleo, onde integram o genoma celular. Dessa forma, o $D N A$ viral é transmitido para todas as células do talo (células vegetativas) da alga, por mitose, onde permanece latente até a formação das células reprodutivas, tanto por esporangiogênese como por gametogênese. A diferenciação celular é o gatilho para a replicação do $D N A$ viral, seguida então da degradação da membrana nuclear e da montagem e liberação dos vírions infecciosos (Wilson et al., 2009).

Os cocolitovírus, incluindo o vírus de Emiliania huxleyi (EhV), possuem uma terceira estratégia de replicação. Enquanto o $P B C V$-1 e o EsV-1 dependem da maquinaria transcricional da célula hospedeira, os cocolitovírus possuem vários genes que codificam para RNA polimerases, o que sugere que sua replicação seria total ou parcialmente independente do núcleo celular. $A$ transcrição viral começa imediatamente após a infecção, provavelmente através de uma RNA polimerase celular, uma vez que não há registro da presença de maquinaria transcricional no vírion maduro. Entre uma e duas horas após a infecção, inicia-se uma segunda fase de transcrição, com a expressão de componentes da RNA polimerase viral; a partir de então, a replicação viral não depende mais do núcleo celular e a transcrição pode ser realizada no citoplasma. Contrariamente aos demais ficodnavírus, cujos vírions se acumulam no citoplasma até que ocorra a lise celular, os vírions de cocolitovírus são liberados gradualmente; acredita-se que proteínas virais interfiram nos esfingolipídeos da parede ou da membrana celular, impedindo morte celular programada e, portanto, prolongando o tempo de infecção celular (Wilson et al., 2009).

Outros representantes da família Phycodnaviridae são o vírus de Chrysochromulina brevifilum (CbV), o vírus de Phaeocystis globosa (PgV), o vírus de Heterosigma akashiwo (HaV-1), o vírus de Micromonas pusilla (MpV), o vírus de Ostreococcus (OsV) e o vírus de Bathycoccus (BpV).

O CbV e o PgV são do gênero Prymnesiovirus e infectam os nanoflagelados predominantemente marinhos Chrysochromulina brevifilum e Phaeocystis globosa, encontrados globalmente e responsáveis por grandes florações. O HaV-1, do gênero Raphidovirus, infecta a cosmopolita alga unicelular marinha Heterosigma akashiwo, a qual é agente de grande impacto ecológico, uma vez que é responsável pelas marés vermelhas (Khan et al., 1997), que acarretam significativas perdas econômicas para a indústria pesqueira, por causarem a morte de várias espécies de peixes, ostras e bivalves (Smayda, 1998). Existem ainda o MpV, do gênero Prasinovirus, o qual infecta o nanoflagelado marinho Micromonas pusilla, e os OsV e BpV, ainda não classificados, que infectam algas verdes marinhas dos gêneros Ostreococcus e Bathycoccus, respectivamente. 
Evidencia-se, assim, que os membros da família Phycodnaviridae infectam uma variedade de algas eucarióticas e, por consequência, influenciam diversos processos relacionados diretamente à ecologia de cada organismo hospedeiro, além de desempenharem importante papel na modulação da dinâmica das populações fitoplanctônicas, influenciando a estrutura e sucessão da comunidade (Castberg et al., 2001; Brussaard, 2004a). De maneira menos específica, os ficodnavírus também influenciam na ciclagem de nutrientes (Gobler et al., 1997; Rusch et al., 2007; Wilhelm e Suttle, 1999) e, potencialmente, na composição atmosférica, já que o fitoplâncton é responsável pela fixação de cerca de metade do dióxido de carbono $\left(\mathrm{CO}_{2}\right)$ do planeta (Sabine et al., 2004; Houghton, 2007; Denman et al., 2007) e libera DMSP quando lisado por vírus (Hill et al., 1998; Malin et al., 1998). Cabe ainda salientar que as infecções virais do cocolitoforídeo marinho Emiliania huxleyi (Figura 6) podem ter significativa importância no registro da história biológica dos oceanos, visto que a alga possui um envoltório carbonático (cocosfera) que permanece como um microfóssil, após a morte do organismo (Armstrong et al., 2005). Esse rico registro fóssil remonta aos últimos 200 mil anos (Brown, 1998).

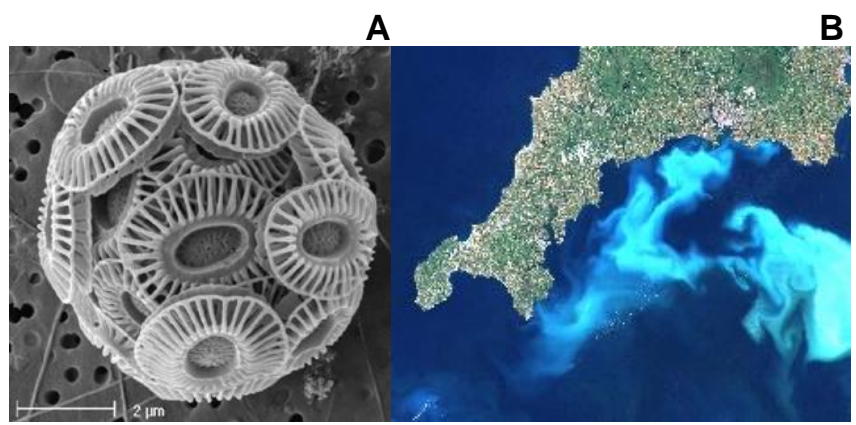

Figura 6. Em A, micrografia eletrônica da alga Emiliania huxleyi. Em B, floração da alga na costa do Reino Unido.

Fonte: Wikipédia [(2010)].

Apesar da grande importância ecológica do grupo e de sua distribuição global (Cottrell e Suttle 1991; Clasen et al., 2008), o conhecimento sobre a replicação dos ficodnavírus ainda é escasso, assim como sobre a história evolucionária e as relações filogenéticas do grupo (Chen e Suttle, 1996; Short e Suttle, 2002; Wilson et al., 2006; Larsen et al., 2008a), especialmente no que tange aos ambientes de água doce (Short e Short, 2008; Clasen e Suttle, 2009).

\subsubsection{Myoviridae}

Os bacteriófagos compõem a maior parte do virioplâncton (Wommack et al., 1992; Maranger et al., 1994) e, assim como os ficodnavírus, também são de grande importância ecológica, pois infectam produtores primários de relevância global como Synechococcus e Prochlorococcus (Waterbury et al., 1986; Partensky et al., 1999). Através da lise das células hospedeiras, os fagos são responsáveis pela disponibilização de macromoléculas, organelas celulares e novas partículas virais, 
que contribuem para o pool de matéria orgânica dissolvida e particulada do ambiente, acelerando a disponibilização de nutrientes na coluna d'água. (Fuhrman, 1992). Por contribuírem significativamente para a mortalidade das populações hospedeiras (Waterbury e Valois, 1993; Suttle e Chan, 1994; Suttle, 2000), acredita-se terem importante papel na manutenção da sua diversidade (Waterbury e Valois, 1993; Suttle e Chan, 1994; Marston e Sallee, 2003; Sullivan et al., 2003), através da infecção da população bacteriana mais abundante - Kill the winner (Thingstad, 2000) e da transferência lateral de genes (Lindell et al., 2004; Coleman et al., 2006; Sullivan et al., 2006).

A família Myoviridae, da ordem Caudovirales, é composta por seis gêneros - T4-like (ex. fago de Enterobacteria T4), P1-like (ex. fago de Enterobacteria P1), P2-like (ex. fago de Enterobacteria P2), Mu-like (ex. fago de Enterobacteria Mu), SP01-like (ex. fago de Bacillus SP01) e $\varphi H$-like (ex. vírus de Halobacterium $\phi \mathrm{H}$ ). Os miofagos possuem cabeça com diâmetro variando de $50 \mathrm{~nm}$ a 100 nm e capsídeo constituído de 152 capsômeros, pescoço e cauda contrátil com comprimento entre 80 $\mathrm{nm}$ e $455 \mathrm{~nm}$ quando estendida e $10 \mathrm{~nm}$ e $15 \mathrm{~nm}$ quando contraída. A cauda possui seis longas fibras terminais, seis espículas curtas e uma placa basal (Figura 7). Assim como os membros das outras famílias da ordem (Siphoviridae e Podoviridae), os miofagos possuem genoma de DNA dupla fita linear entre 33,6 Kb e $170 \mathrm{~Kb}$ (ICTV). Em 2005, Filée et al. propuseram a divisão dos fagos T4-like em subgrupos - T-even, Pseudo T-even, Schizo T-even e Exo T-even, com base em filogenia, sendo este último o grupo mais divergente, o qual inclui os cianofagos marinhos (Filée et al., 2005).

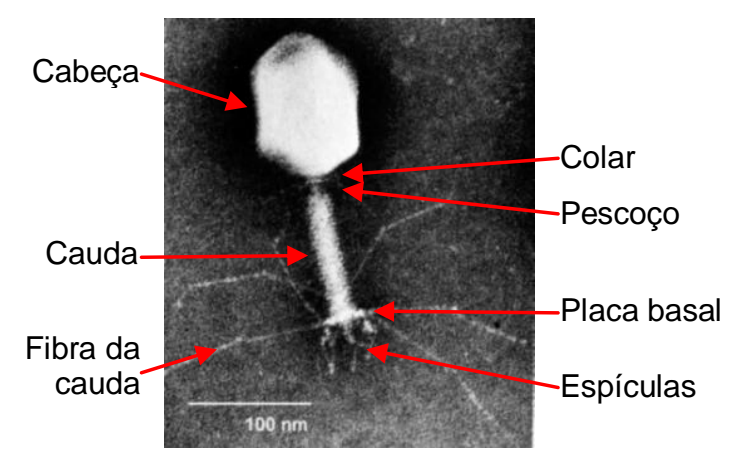

Figura 7. Micrografia eletrônica de fago T4.

Fonte: The Universal Virus Database of the International Committee on Taxonomy of Viruses [(2010)].

O fago T4 é o arquétipo da família Myoviridae. Seu genoma possui aproximadamente $169 \mathrm{~Kb}$, com 289 genes que codificam proteínas, oito que codificam RNA transportador e pelo menos dois genes que codificam pequenos RNAs estáveis, sem função conhecida (ANEXO B) (Miller et al., 2003). O complexo aparato da partícula viral é utilizado para injetar o DNA do fago na célula. As extremidades das fibras da cauda fazem o contato inicial com os receptores da superfície celular e, uma vez que o fago está ancorado, movimentos randômicos promovem o contato da placa basal com a superfície celular. Esses processos iniciais são o gatilho para alterações conformacionais na cauda: 
o centro da placa basal se abre, permitindo que a porção interna da cauda passe enquanto a porção externa se contrai, promovendo a penetração da porção central na célula e consequente liberação do DNA viral em seu interior (Knipe e Howley, 2007). A partir de então, inicia-se a replicação viral, através da transcrição de três grupos de genes: os precoces, os intermediários e os tardios. De maneira geral, os genes precoces e intermediários codificam enzimas envolvidas na replicação e transcrição do DNA viral e os genes tardios codificam as proteínas da cabeça e da cauda, além de enzimas envolvidas na liberação dos fagos maduros (Figura 8) (Madigan et al., 2000).

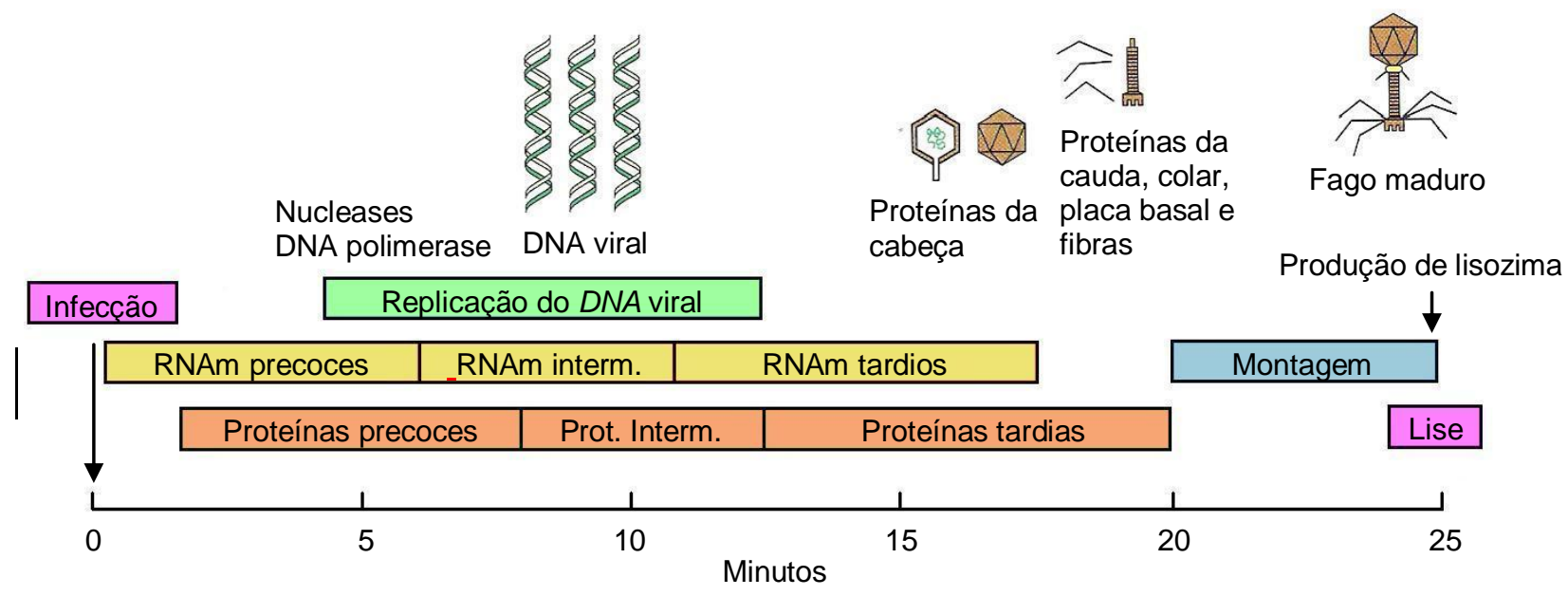

Figura 8. Infecção por fago T4 - cronologia. Fonte: Madigan et al. (2000).

A montagem das novas partículas virais se dá pela formação independente das estruturas da cabeça, da cauda e das fibras, que são posteriormente unidas (Figura 9) (Knipe e Howley, 2007). Cabe ressaltar que o capsídeo viral não é produzido diretamente no seu formato final; proteínas internas de estruturação (scaffolding) preenchem o interior do capsídeo primário (prohead) e são posteriormente expelidas através de seus orifícios, fazendo com que o capsídeo expanda até o formato definitivo, antes da entrada do DNA. A proteína gp23, alvo deste estudo, é uma das proteínas de estruturação (scaffolding) envolvidas no processo descrito acima, juntamente com a proteína gp24 (Knipe e Howley, 2007).

Dentre os fagos marinhos, membros da família Myoviridae são isolados com maior frequência que os das demais (Kellogg et al., 1995; Wichels et al., 1998; Sullivan et al., 2003). Estes infectam uma vasta gama de bactérias, possivelmente por possuírem em seu DNA uma base diferenciada, a 5-hidroximetilcitosina, a qual garante ao $D N A$ viral resistência a muitas enzimas de restrição do hospedeiro; quando glicosilada, a 5-hidroximetilcitosina confere ao DNA viral resistência à praticamente todas as endonucleases da célula hospedeira (Madigan et al., 2000). Os miofagos são tipicamente líticos e podem rapidamente tirar proveito do aumento da população hospedeira, através 
do seu curto tempo de geração e das altas taxas de replicação, sendo, possivelmente, estrategistas $r$.

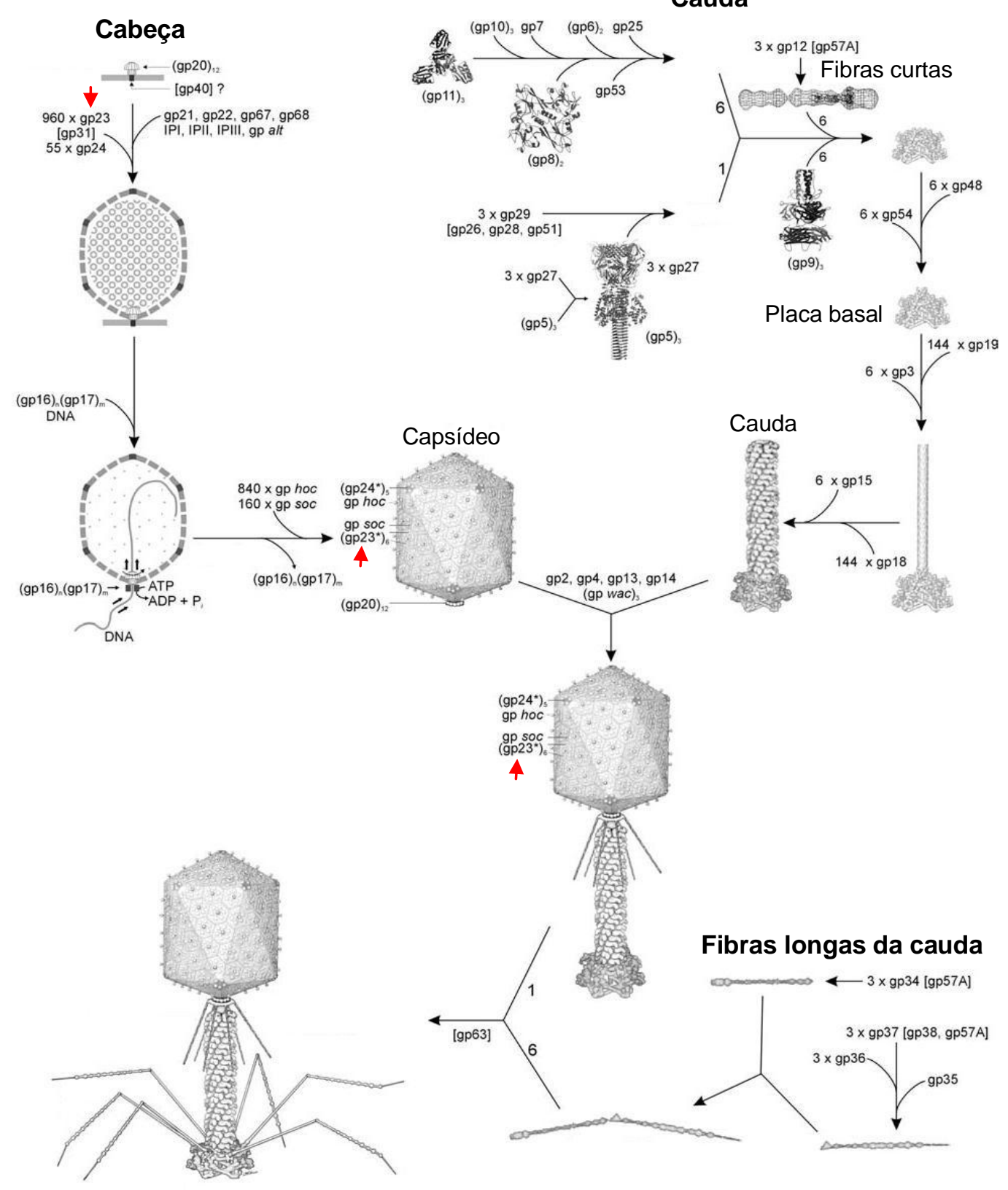

Figura 9. Morfogênese do vírion do fago T4. Ênfase para a proteína gp23 $(\rightarrow)$. Fonte: Leiman et al. (2003). 


\subsubsection{Métodos aplicados no estudo do virioplâncton}

Apesar de os vírus estarem presentes em grande número nos ambientes aquáticos, estudos que requerem 0 uso de técnicas baseadas na análise do material genético desses agentes empregam uma etapa de concentração viral para garantir a obtenção de massa de material genético suficiente para as técnicas moleculares subsequentes.

Em resumo, amostras de água com volumes bastante variados são, primeiramente, clarificadas por filtração, para remoção de material particulado grosso e células bacterianas, e, em seguida, concentradas através de diferentes tipos de filtração (Paul et al., 1991; Suttle et al., 1991; Wommack et al., 1995; Larsen et al., 2008a), ultracentrifugação (Short e Short, 2008), ou ainda através do emprego de uma combinação das técnicas (Mehnert e Stewien, 1993; Larsen et al., 2001). A escolha por uma técnica em detrimento das demais normalmente se justifica pelo tipo de amostra, pela infraestrutura disponível no local de coleta (especialmente no caso de coletas marinhas embarcadas ou em locais de logística complexa, como os ambientes polares, onde há restrição de espaço e/ou peso de equipamento), e até pelo knowhow do grupo de pesquisa onde o trabalho é realizado.

A técnica de ultrafiltração, preconizada por Suttle et al. (1991), consiste na filtração tangencial do volume previamente clarificado através de um cartucho contendo membrana que selecione determinado peso molecular (valor de corte); dessa maneira, o material de peso molecular maior que o valor de corte (incluindo os vírus) fica retido, realimentando o sistema, e o material com peso molecular menor que o valor de corte é eliminado do sistema, resultando na diminuição gradual do volume da amostra e sua consequente concentração. Esse método tem uma eficiência de mais de $80 \%$ na recuperação das partículas virais das amostras.

A contagem de partículas virais em dada amostra de água é bastante utilizada para a verificação da eficiência dos métodos de concentração viral, além de ser aplicada em estudos de cunho ecológico. Tradicionalmente, o título viral era determinado indiretamente através do método de plaqueamento (Adams, 1959). Entretanto apenas uma pequena quantidade do virioplâncton pode ser cultivada (MacLeod, 1965), de modo que os resultados eram constantemente subestimados. Com o desenvolvimento de métodos de enumeração direta, a análise da abundância viral em ambientes aquáticos foi bastante facilitada. A microscopia eletrônica de transmissão (MET) passou então a ser a técnica mais utilizada (Proctor et al., 1988; Bergh et al., 1989; Proctor e Fuhrman, 1990; Sieburth et al., 1988), apesar de apresentar limitações práticas e técnicas que resultavam na subestimação do título viral (Wommack et al., 1992; Suttle, 1993), como o encobrimento de partículas virais por outras presentes na amostra. Com a introdução do uso de corantes de DNA conjuntamente à microscopia de epifluorescência, essas limitações foram ultrapassadas e os resultados passaram a fornecer as primeiras estimativas corretas sobre a abundância dos vírus em ambientes aquáticos (Bergh et al., 1989; Proctor e Fuhrman, 1990). Com o tempo, a técnica foi sendo aprimorada através da utilização 
de corantes de DNA cada vez mais eficazes (DAPI: Hara et al., 1991; Hara et al., 1996 - Yo-Pro-l: Hennes e Suttle, 1995; Weinbauer e Suttle, 1997 - SYBR Green-I: Noble e Fuhrman, 1998; Marie et al., 1999).

Mais recentemente, o uso da citometria de fluxo na contagem viral mostrou-se bastante eficaz e sua aplicação viabilizou o processamento de grande número de amostras em tempo reduzido, tendo ainda como vantagem o fato de apresentar resultados independentes do operador, diferentemente das técnicas baseadas em microscopia (Brussaard et al., 2000; Brussaard, 2004b).

O método DGGE (Denaturing Gradient Gel Electrophoresis) é comumente utilizado em estudos de diversidade viral e microbiana e possibilita a fácil verificação de sequências genéticas diferentes e dominantes presentes nas amostras, através de perfis eletroforéticos (fingerprints). Tal método, preconizado por Fischer e Lerman (1979), para aplicação médica, foi primeiramente utilizado em estudo da diversidade de populações bacterianas de biofilmes, em 1993, quando Muyzer et al. analisaram fragmentos do gene $16 \mathrm{~S}$ rDNA de bactérias anaeróbias (Muyzer et al., 1993). Desde então, o DGGE tem sido aplicado no estudo da microbiota de outros ambientes, como em regiões marinhas costeiras (Ogino et al., 2001), biofilmes de fontes termais (Ferris et al., 1996), estuários (Murray et al., 1996) e no Ártico (Ferrari e Hollibaugh, 1999). Em 1999, foi aplicado pela primeira vez em estudo sobre a diversidade de vírus algais (Short e Suttle, 1999) e padronizado para o uso em estudos de ecologia viral no ano seguinte, pelos mesmos pesquisadores (Short e Suttle, 2000) e, em 2003, por Schroeder (Schroeder, 2003).

O DGGE baseia-se nas diferenças nucleotídicas das sequências de $D N A$, ainda que do mesmo tamanho. Em gel de acrilamida, com gradiente denaturante, o DNA dupla fita é submetido a um ambiente crescente de denaturação, o qual ocasionará a separação da dupla fita, gerando melting domains. Quando a temperatura de anelamento $(T m)$ do menor melting domain é alcançada, a dupla fita de DNA denatura parcialmente, diminuindo a motilidade do DNA no gel de poliacrilamida. Uma vez que a $T m$ é característica de cada sequência de $D N A$, alterações na sequência irão resultar em padrões de migração diferentes no gel, possibilitando a fácil identificação de sequências diferentes.

Abordagens independentes de cultura têm indicado que conhecemos apenas uma porção muito reduzida da diversidade viral dos oceanos, lagos e rios. Na tentativa de suprimir essa lacuna, estudos têm sido realizados baseados em técnicas moleculares, que frequentemente exigem 0 conhecimento das sequências dos genomas virais completos ou parciais, como no caso de estudos filogenéticos e de dinâmica populacional. Entretanto, vírus não possuem um gene evolutivamente conservado comum a todos, como, por exemplo, o $16 \mathrm{~S}$, no caso das bactérias, fato que impõe a pesquisadores a utilização de genes conservados entre os membros de cada grupo viral de interesse.

No caso dos ficodnavírus, a grande maioria dos estudos, incluindo este, baseia-se no gene da $D N A$ polimerase ( $p o l)$, o qual contém o domínio da polimerase, que é altamente conservado no nível 
de aminoácido, mas apresenta variações no nível de nucleotídeo (Zhang e Suttle, 1994). Já estudos sobre miofagos utilizam-se de genes estruturais como o gp20 (Fuller et al., 1998; Zhong et al., 2002) e o gp23 (Filée et al., 2005), que codificam glicoproteínas de superfície, sendo o gp23 o utilizado neste trabalho.

\subsection{Reconstruções filogenéticas}

A sistemática filogenética é a área da Biologia que tem por objetivo a reconstrução da história evolucionária e o estudo de padrões das relações filogenéticas entre organismos (Henning, 1966), a qual utiliza, basicamente, três conjuntos de métodos para a realização das inferências: métodos de parcimônia, de distância e de verossimilhança (Felsenstein, 1988).

Neste estudo, o método aplicado foi o de verossimilhança, que se baseia na reconstrução das árvores em matrizes de probabilidades instantâneas de substituições entre nucleotídeos, as quais explicitam modelos evolutivos para a inferência dos estados ancestrais a partir dos estados observados (Harris e Stocker, 1998), possibilitando a avaliação das probabilidades de cada substituição verificada no conjunto de dados, sítio a sítio.

O método de verossimilhança possui três elementos - os dados, as hipóteses (constituídas pela topologia da árvore e pelo comprimento de ramos variáveis) e um modelo probabilístico específico, segundo o qual as hipóteses serão verificadas. A verossimilhança, portanto, não se refere à probabilidade de que a árvore seja correta, mas sim, à probabilidade de se observar a ocorrência do dado posto uma hipótese (topologia) e um modelo (Romano, 2009).

Nesse método, a utilização de modelos de evolução que possam predizer as probabilidades de ocorrência de cada transformação de um estado para o outro é imprescindível, já que, diferentemente dos métodos de distância, a divergência entre um par de sequências não é interpretada como um único valor, sendo estimada para cada sítio ao longo da árvore. Desse modo, quando a divergência entre as sequências observadas é baixa, a distância é um estimador fiel da real distância genética. À semelhança, quanto maior a divergência entre as sequências, maior a chance de subestimação da distância observada, o que resulta na necessidade de uma correção estatística (Romano, 2009). Tal correção é feita por modelos de substituição de nucleotídeos e, no caso deste estudo, o modelo adotado foi o JTT (Jones et al., 1992).

O método Bayesiano de reconstrução filogenética, assim como o de verossimilhança, leva em consideração a variação de taxas dentro de um conjunto de sequências. Esse método, em vez de procurar uma árvore ótima, procura um conjunto de árvores que possuam probabilidade de representar os dados, posto um modelo de evolução e premissas admitidas a priori. O método Bayesiano tem sido aplicado, além de na filogenética, em estudos de variações entre taxas de substituição entre ramos (Huelsenbeck et al., 2000), de tempo de divergência entre linhagens (Thorne 
et al., 1998), e de relógio molecular (Suchard et al., 2001; Romano et al., 2008). No presente trabalho, análises Bayesianas foram utilizadas no estudo da filodinâmica dos ficodnavírus.

\section{3 Área de estudo}

A bacia Amazônica é partilhada por oito países, sendo que cerca de $60 \%$ de sua área $(3,5$ milhões de $\mathrm{km}^{2}$ ) encontra-se em território brasileiro, o que faz do Brasil um dos países mais ricos em biodiversidade do mundo.

O Amazonas e o Negro, dois dos principais rios da bacia, apensar de geograficamente próximos, foram formados por processos geológicos distintos, resultando em corpos de água com características químicas, físicas e físico-químicas totalmente diferentes (Cunha e Pascoaloto, 2006).

O Rio Amazonas nasce no lago Lauricocha, nos Andes peruanos, e tem como nomes Tunguragua e Marañon. Quando entra em território brasileiro, recebe o nome de Solimões até a boca do Rio Negro, onde passa a ser chamado de Amazonas. Tem $5.825 \mathrm{Km}$ de extensão e cerca de 1.000 afluentes, formando a maior bacia hidrográfica do mundo. O Solimões é considerado um rio de "águas-brancas" (Sioli, 1975a; Sioli, 1975b), com águas turvas, de coloração em vários matizes de ocre, ricas em material particulado em suspensão, com relativamente alta quantidade de eletrólitos e $\mathrm{pH}$ variando de 6,2 a 7,2 .

O Rio Negro nasce na serra do Junai (Colômbia), sob a denominação de Guainia e corre por $1.200 \mathrm{Km}$ - dos $1.700 \mathrm{Km}$ de extensão total - em território brasileiro, até a foz no Rio Amazonas. É considerado um rio de "águas-pretas" (Sioli, 1975a; Sioli, 1975b), com coloração marrom-café, devido à grande quantidade de substâncias húmicas e fúlvicas dissolvidas, oriundas da decomposição de grande quantidade de matéria orgânica. Suas águas são ácidas ( $\mathrm{pH} \mathrm{3,8} \mathrm{a} \mathrm{4,9),} \mathrm{pouco} \mathrm{ionizadas}$ (baixa condutividade) e escassas em sais dissolvidos, fato que representa bem a pobreza química dos solos por onde as águas correm.

O Rio Cuieiras é um tributário do rio Negro, que tem sua nascente na Reserva do Rio Cuieiras ZF-2, desaguando a $80 \mathrm{Km}$ ao norte da cidade de Manaus. Corre por território de insignificativa atividade antrópica e suas águas possuem características semelhantes às do Rio Negro, uma vez que também é considerado um rio de "águas-pretas" (Sioli, 1975a; Sioli, 1975b).

Os primeiros estudos realizados nos rios amazônicos datam do século XIX, da época em que as expedições eram patrocinadas pelos governos europeus, e tiveram como objetivo a análise da qualidade das águas. Mais tarde, na metade do século XX, novos estudos foram realizados por Harold Sioli, um pesquisador alemão que tornou mundialmente conhecidos os diferentes tipos de água dos rios da Amazônia. Quanto às características físicas, físico-químicas e químicas das águas, existem estudos realizados em alguns rios e subafluentes, sendo o mais completo e de fácil consulta 
o de Santos e Ribeiro (1988), que investigou 32 afluentes do Amazonas, desde a cidade de Tabatinga (AM) até Santarém (PA).

Apesar de muitos estudos terem sido feitos, desde então, sobre a floresta propriamente dita e as inúmeras espécies de mamíferos e peixes da região, enfatizando-se a questão da biodiversidade, o mesmo não ocorreu em relação às águas. Ainda hoje, muito pouco se conhece a respeito da microbiota aquática (Benner et al., 1995; Hungria et al., 2005; Rejas et al., 2005; Hewson et al., 2006) e não existem publicações sobre a comunidade viral natural dos rios da região, havendo apenas raros trabalhos sobre a ocorrência de vírus entéricos em amostras ambientais da região de Manaus (De Paula et al., 2007; Miagostovich et al., 2008; Ferreira et al., 2009).

\subsection{Importância limnológica de parâmetros físicos, químicos e biológicos}

Para que seja possível uma compreensão completa da biota e microbiota aquáticas, assim como dos processos nos quais estão envolvidas, é interessante que se conheça o significado ecológico dos parâmetros físicos e químicos da água.

A quantidade de luz que penetra na coluna d'água exerce grande influência sobre a produção primária do ambiente, visto que é fator limitante à fotossíntese (Wetzel, 2001). A medida de oxigênio é de fundamental importância em sistemas aquáticos, uma vez que o gás é indispensável ao metabolismo de todos os organismos aeróbios. Assim, dados da solubilidade e da dinâmica da distribuição de oxigênio nos rios são necessários ao entendimento da distribuição, comportamento e crescimento dos organismos aquáticos. Além disso, através da medida de demanda bioquímica de oxigênio (DBO), compreendida como a quantidade de oxigênio utilizada na oxidação de matéria orgânica em determinado período de tempo, é possível verificar a saúde do corpo d'água. Isso porque ambientes eutrofizados vão apresentar grande quantidade de matéria orgânica e, portanto, elevada DBO (Wetzel, 2001).

O nitrogênio é um nutriente essencial à vida, uma vez que integra proteínas, ácidos nucleicos e outras biomoléculas. É encontrado em ecossistemas aquáticos em diferentes formas, solúveis e insolúveis, determinando a assimilação ou não por micro-organismos (Sigee, 2005). O nitrato é a principal forma de nitrogênio biodisponível. Ele entra nos sistemas aquáticos através da chuva e do próprio solo, na forma inorgânica, e é assimilado pelo fitoplâncton, sendo transformado em forma orgânica. Com a morte dos organismos, o nitrogênio volta à coluna d'água como constituinte de macromoléculas (detritos) e é então transformado em amônia, através do processo de remineralização. A oxidação biológica da amônia a nitrato é o processo de nitrificação, o qual transforma o nitrogênio orgânico novamente em inorgânico, e biodisponível através de duas etapas: a primeira, de amônia a nitrito, e a segunda, de nitrito a nitrato (Sigee, 2005).

Dessa forma, o nitrato é a forma mais completamente oxidada do nitrogênio, formado durante os estágios finais da decomposição biológica. O nitrito, por sua vez, um estado intermediário do ciclo 
do nitrogênio, é formado durante a decomposição da matéria orgânica e prontamente oxidado a nitrato. Em função disso, em águas superficiais, a presença de nitritos pode indicar a decomposição parcial de matéria orgânica e a descarga excessiva oriunda de estação de tratamento de água ou poluição industrial. Portanto, assim como o oxigênio, as concentrações das diferentes formas de nitrogênio na água fornecem um panorama da saúde do ambiente (Sigee, 2005).

Assim como o nitrogênio, o fósforo também é um nutriente essencial à vida, presente nas membranas celulares, além de estar envolvido nas transformações energéticas celulares. Na maioria dos ambientes aquáticos, o fósforo é o principal fator limitante da produção primária e, por isso, quando encontrado em altas concentrações, evidencia a eutrofização do ambiente (Sigee, 2005).

Uma outra maneira de medir o grau de poluição de determinado ambiente aquático é por meio da análise da comunidade fitoplanctônica. O índice de Palmer (1969) é um dos utilizados para fazer essa medição e baseia-se na presença de determinados gêneros de algas conhecidamente resistentes à poluição orgânica na amostra de água. Em resumo, a cada um dos gêneros indicadores corresponde um índice de poluição, sendo que a soma dos índices dos gêneros de algas presentes na amostra maior ou igual a 20 indica alta poluição orgânica, e somas variando de 15 a 19 indicam uma provável evidência de alta poluição. Dentre os gêneros com maior indicador de poluição estão Oscillatoria (5), Euglena (5), Scenedesmus (4) e Chyamydomonas (4) (Palmer, 1969).

Sabendo que a poluição orgânica das águas exerce maior influência sobre o fitoplâncton do que outros fatores físicos e químicos como dureza da água, intensidade de luz, pH, OD e temperatura, índices que avaliem essa comunidade fornecem dados importantes para verificação do estado trófico do ambiente aquático (Palmer, 1969). 


\section{OBJETIVOS}

\subsection{Objetivos gerais}

Os objetivos gerais deste projeto foram analisar as populações de ficodnavírus e miofagos em amostras amazônicas e determinar um possível impacto do lançamento de efluentes domésticos sobre essas populações.

\subsection{Objetivos específicos}

- Caracterizar as amostras dos rios Cuieiras, Negro e Solimões em relação a parâmetros físicos e químicos.

- Determinar a presença de vírus das famílias Phycodnaviridae e Myoviridae, nas amostras amazônicas, por microscopia eletrônica de transmissão e por amplificação gênica por $P C R$ (Polimerase Chain Reaction).

- Caracterizar as amostras dos três rios quanto à riqueza das populações de ficodnavírus e miofagos, por DGGE (Denaturing Gradient Gel Electrophoresis).

- Construir uma biblioteca gênica de ficodnavírus e de miofagos a partir das amostras de água analisadas.

- Realizar estudos filogenéticos de miofagos e de ficodnavírus, incluindo os clones amazônicos e de outras localidades, e vírus isolados.

- Analisar a movimentação dos ficodnavírus entre ambientes lóticos, lênticos e marinhos.

- Analisar a dinâmica populacional dos ficodnavírus detectados no presente estudo conjuntamente com os de diversos ambientes aquáticos do planeta.

- Fazer um levantamento do fitoplâncton presente nas amostras amazônicas.

- Determinar possíveis interferências do lançamento de efluentes domésticos no rio Negro sobre as características da água e sobre populações locais virais das famílias Phycodnaviridae e Myoviridae, e fitoplanctônicas. 


\section{MATERIAIS E MÉTODOS}

\subsection{Locais de coleta}

As coletas de amostras de água foram realizadas em três rios da região amazônica: Cuieiras $(n=1)$, Negro $(n=4)$ e Solimões ( $n=3)$ (Figuras 10 e 11). No rio Cuieiras (CUI), a amostra foi coletada na região da nascente. No rio Negro, as amostras foram coletadas em duas estações, uma à montante (NEGM) e uma à jusante (NEGJ) de Manaus, nas regiões do Tatu e Educandos, respectivamente. No rio Solimões (SOL), as amostras foram coletadas em apenas uma estação, próxima à llha da Machantaria. As amostras NEGM e SOL foram coletadas em ambas as margens e no centro do canal, e a NEGJ, somente na margem esquerda do rio (Tabela 1).

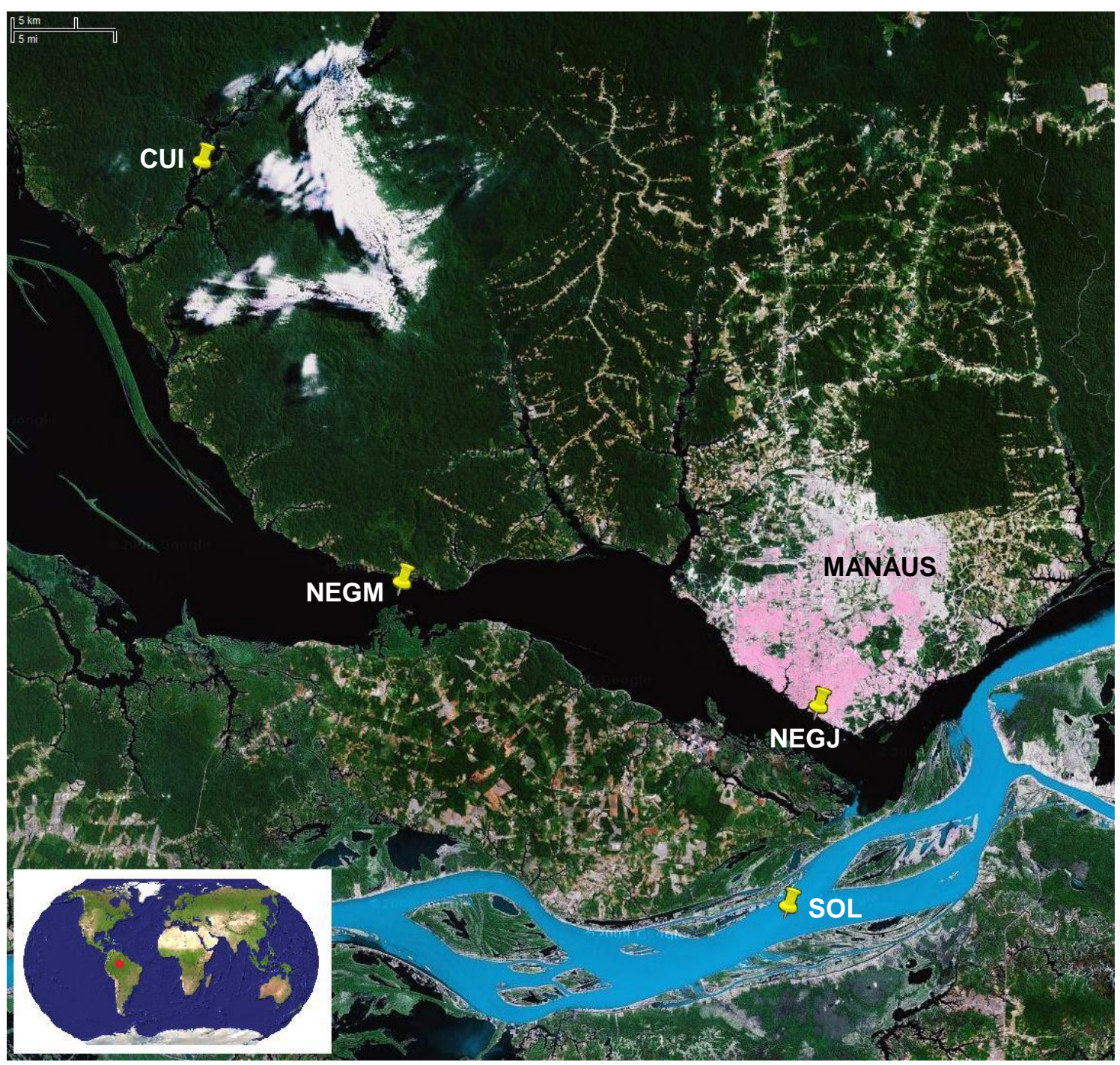

Figura 10. Mapa da região amostrada, com indicação da cidade de Manaus e das estações de coleta nos rios Cuieiras (CUI), Negro (NEGM e NEGJ) e Solimões (SOL). 

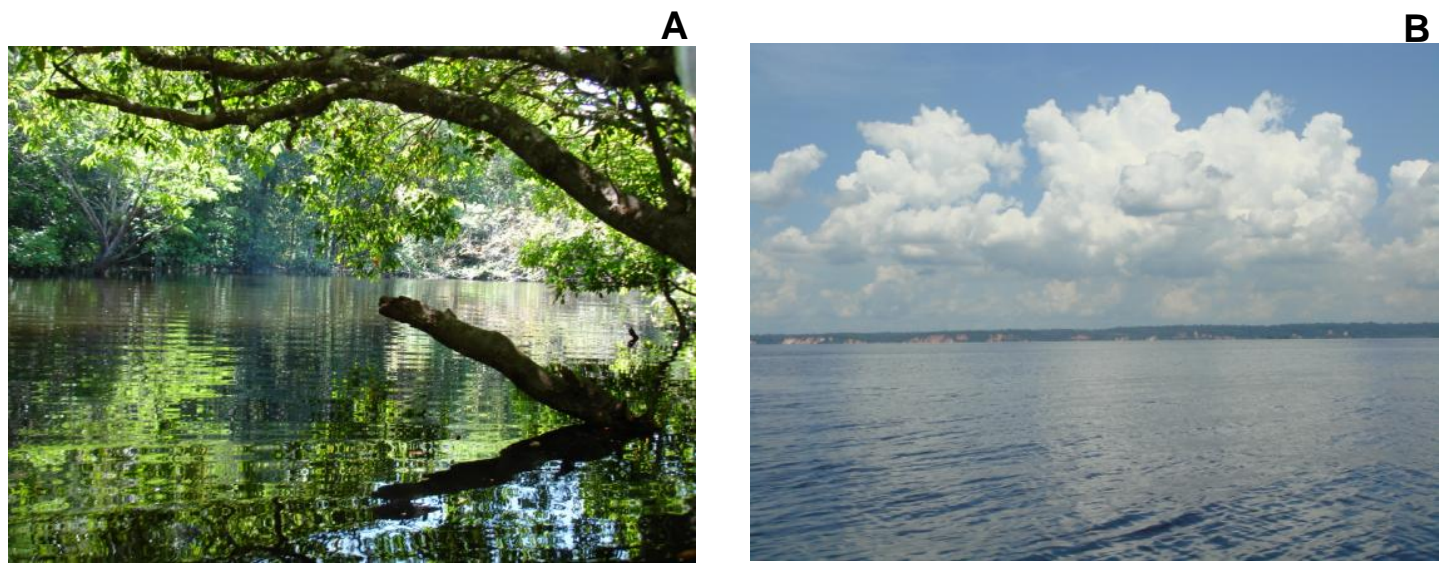

C

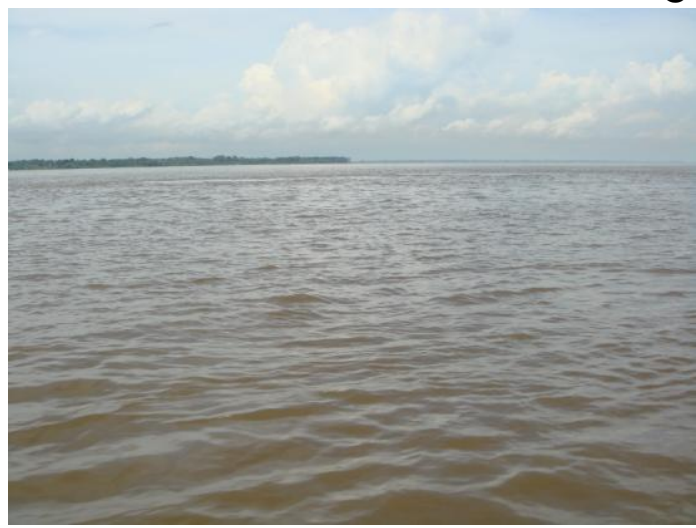

Figura 11. Rios amostrados: Cuieiras (A), Negro (B), Solimões (C).

Tabela 1 - Informações das amostras coletadas.

\begin{tabular}{|c|c|c|c|c|}
\hline Data & Amostra & Rio & Localização & Coordenadas \\
\hline $17 / 07 / 2007$ & NEGM-1 & Negro $^{1}$ & Tatu & $\begin{array}{l}03^{\circ} 03^{\prime} \mathrm{S} \\
60^{\circ} 18^{\prime} \mathrm{O}\end{array}$ \\
\hline $18 / 07 / 2007$ & SOL-1 & Solimões & Ilha da Machantaria & $\begin{array}{l}03^{\circ} 16^{\prime} \mathrm{S} \\
60^{\circ} 02^{\prime} \mathrm{O}\end{array}$ \\
\hline 19/07/2007 & NEGJ-1 & Negro $^{2}$ & Educandos & $\begin{array}{l}03^{\circ} 08^{\prime} \mathrm{S} \\
60^{\circ} 01^{\prime} \mathrm{O}\end{array}$ \\
\hline 20/07/2007 & NEGM-2 & Negro $^{1}$ & Tatu & $\begin{array}{l}03^{\circ} 03^{\prime} \mathrm{S} \\
60^{\circ} 18^{\prime} \mathrm{O}\end{array}$ \\
\hline 23/07/2007 & SOL-2 & Solimões & Ilha da Machantaria & $\begin{array}{l}03^{\circ} 16^{\prime} \mathrm{S} \\
60^{\circ} 02^{\prime} \mathrm{O}\end{array}$ \\
\hline $24 / 07 / 2007$ & CUI-1 & Cuieiras & Nascente & $\begin{array}{l}02^{\circ} 46^{\prime} \mathrm{S} \\
60^{\circ} 27^{\prime} \mathrm{O}\end{array}$ \\
\hline $25 / 07 / 2007$ & NEGM-3 & Negro $^{1}$ & Tatu & $\begin{array}{l}03^{\circ} 03^{\prime} \mathrm{S} \\
60^{\circ} 18^{\prime} \mathrm{O}\end{array}$ \\
\hline 26/07/2007 & SOL-3 & Solimões & Ilha da Machantaria & $\begin{array}{l}03^{\circ} 16^{\prime} \mathrm{S} \\
60^{\circ} 02^{\prime} \mathrm{O}\end{array}$ \\
\hline
\end{tabular}

1 à montante de Manaus

2 à jusante de Manaus 


\subsection{Coleta de amostras de água}

Durante o mês de julho de 2007 (período de estiagem, porém cheia dos rios), volumes variados de água, de acordo com o propósito de cada amostra, foram coletados aproximadamente a $1,5 \mathrm{~m}$ de profundidade, com auxílio de bomba de sucção. A profundidade de amostragem foi escolhida no momento da primeira coleta, baseada na profundidade limite da zona eufótica (1\%), calculada a partir da medida da leitura do disco de Secchi obtida no local. As coletas foram realizadas abaixo da superfície e dentro da zona eufótica, para evitar as variáveis associadas à superfície (como alta exposição à radiação ultravioleta e turbilhões), e para garantir a amostragem da comunidade viral associada a hospedeiros fotossintetizantes.

Amostras para análise molecular foram coletadas em galões de polipropileno de $20 \mathrm{~L}$ e os volumes variaram de $10 \mathrm{~L}$ (amostra SOL-1) a $100 \mathrm{~L}$ (amostras NEGM), sendo a amostra CUI-1 de 40 L, a NEGJ-1 de 80 L e as SOL-2 e SOL-3 de 20 L cada. Para análise do fitoplâncton, alíquotas de 20 $\mathrm{mL}$ de água foram coletadas em frasco de vidro contendo $0,4 \%$ de formol. Todas as amostras foram transportadas para o laboratório protegidas da luz e calor e processadas em até três horas após coletadas, no intuito de preservar o mais fielmente possível as condições da amostra às condições originais.

\subsection{Parâmetros físicos}

Todos os parâmetros físicos foram medidos in loco, durante a coleta de água.

\subsubsection{Profundidade da zona eufótica (1\%)}

A estimativa da extensão da zona fótica dos rios foi realizada através de cálculos baseados na profundidade medida pelo disco de Secchi, segundo Margalef (1983). Em resumo, o valor médio de transparência da água, obtido pela visibilidade do disco de Secchi foi multiplicado pelo coeficiente empírico 2,7.

\subsubsection{Temperatura da água}

A temperatura da água foi medida com termômetro digital, marca 3000 T-L-C-Meter (Temperature - Level - Conductivity). O aparelho realiza a leitura automaticamente, compensando $2 \% /{ }^{\circ} \mathrm{C}$ para $25{ }^{\circ} \mathrm{C}$.

\subsubsection{Potencial hidrogeniônico $(\mathrm{pH})$}

$\mathrm{O} \mathrm{pH}$ das amostras, definido como o logaritmo negativo de concentração de íons $\mathrm{H}^{+}(\mathrm{pH}=-$ $\log \left[\mathrm{H}^{+}\right]$), foi medido por potenciometria, com potenciômetro digital Oakton, modelo pH 2500 série, com eletrodos calibrados com soluções tampões em pH 4,0 e pH 7,0 (APHA, 1985). 


\subsection{Parâmetros químicos}

Todas as amostras utilizadas para obtenção de dados referentes aos parâmetros químicos foram coletadas seguindo o procedimento descrito no item 4.2 e analisadas pelo Laboratório de Química Ambiental do Instituto Nacional de Pesquisas da Amazônia (INPA), sob supervisão da Dra. Hillândia Brandão da Cunha.

\subsubsection{Oxigênio dissolvido (OD)}

As amostras, fixadas no local de coleta com solução de azida supersaturada e sulfato manganoso $(50 \%(\mathrm{~m} / \mathrm{v}))$, a fim de manter as características originais do ambiente, foram analisadas no laboratório no mesmo dia da coleta. A concentração de OD foi medida através do método de Winkler (1888), modificado por Pomeroy e Kirshman (1945).

\subsubsection{Demanda bioquímica de oxigênio (DBO)}

A DBO foi determinada pelo mesmo método utilizado para medir OD, sendo que as amostras foram mantidas, por cinco dias, envoltas em papel alumínio para evitar a produção de oxigênio por fotossíntese antes da leitura.

\subsubsection{Nutrientes}

As concentrações de ânions e cátions dissolvidos foram determinadas por cromatografia líquida em equipamento da marca DIONEX, modelo ICS1000. A detecção foi feita por condutivimetria com colunas analíticas distintas para ânions e cátions, lonPac AS9HC (4 mm) e CS12A (4 mm), respectiva e simultaneamente. Para a detecção de ânions, foi empregada uma solução eluente composta por carbonato de sódio $(11 \mathrm{mM})$ e bicarbonato de sódio $(7 \mathrm{mM})$, enquanto que, para a detecção de cátions, foi utilizada uma solução eluente de ácido metanosulfônico (20 mM). As análises foram gerenciadas automaticamente por computador, com o auxílio do programa Peaknet 6.7, e os resultados foram obtidos através de uma curva de calibração com padrões externos. O controle de qualidade da quantificação dos resultados foi feito com o uso da amostra certificada Tróis-94.

\subsection{Identificação e contagem do fitoplâncton}

A identificação e contagem das células fitoplanctônicas foram realizadas pelo Laboratório de Ecologia do Fitoplâncton e Produção Primária do Instituto Oceanográfico da USP, sob supervisão da Dra. Sônia Gianesella. Em suma, as amostras fixadas no momento da coleta (vide item 4.2) foram analisadas através de microscopia óptica.

A identificação do fitoplâncton de água doce é especifica para cada grupo. Para as categorias taxonômicas infraclasses e identificação dos táxons foram utilizadas obras especializadas para cada grupo, principalmente: Desikachary (1959), Komárek e Anagnostidis (2005), Sant'anna et al. (1995) para Cyanophyceae; Fensome et al. (1993) para Dinophyceae; Huber-Pestalozzi (1955), Marin et al. 
(2003), Kosmala et al. (2007), Tell e Conforti (1986) para Euglenophyceae; Huber-Pestalozzi (1961), Komárek e Fott (1983), Sant'anna (1984) para Chlorophyceae; Förster (1969) para Zygnematophyceae; Ettl (1978) para Xantophyceae; Huber-Pestalozzi (1962) para Chrysophyceae; Patrick e Reimer (1966), Hendey (1964), Hustedt (1955, 1927-66, 1985), Peragallo e Peragallo (1965), Krammer e Lange-Bertalot (1986, 1988, 1991), e Metzeltin e Lange-Bertalot (1998) para Coscinodiscophyceae, Fragilariophyceae e Bacillariophyceae.

\subsection{Obtenção dos concentrados virais}

No laboratório do INPA, as amostras de água de ambas as margens e do centro do canal foram processadas como uma mesma amostra mista. Estas foram filtradas em papel-filtro (Whatman 40), membrana de fibra de vidro de porosidade de 1,2 $\mu \mathrm{m}$ (Millipore) e em membrana de fluoreto de polivinilideno ( $P V D F)$ - Durapore ${ }^{\circledR}$ de porosidade de $0,45 \mu \mathrm{m}$ (Millipore), acondicionados em dois suportes de aço inox de $142 \mathrm{~mm}$ de diâmetro (Millipore), ligados em sequência, sendo que o primeiro suporte continha o papel-filtro e a membrana de fibra de vidro (Figura 12A) e o segundo suporte, a membrana de PVDF.

$\mathrm{Na}$ sequência, o material obtido na filtração foi submetido à ultrafiltração tangencial no sistema Prep Scale ${ }^{\circledR}$ TFF-6 da Millipore ${ }^{\circledR}$, montado com cartucho de membrana de celulose regenerada (tipo PL), segundo método descrito por Suttle et al. (1991) e orientações do fabricante (Figura 12B).
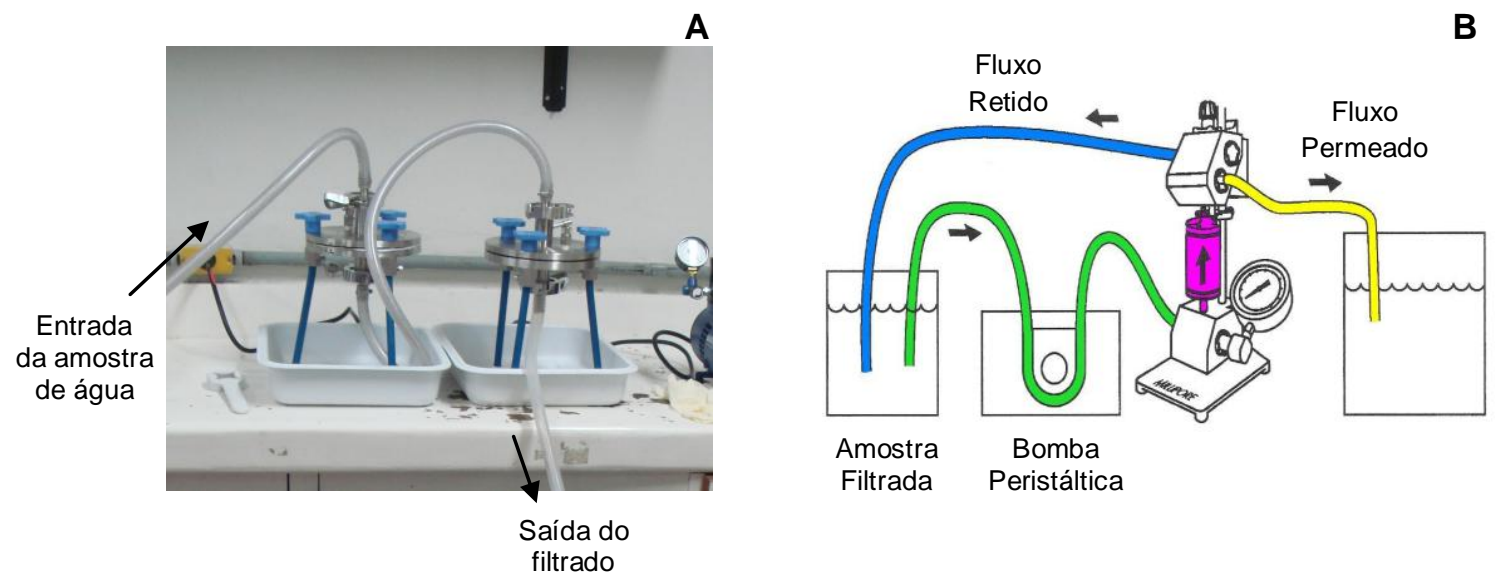

Filtrada Peristáltica

Figura 12. Sistema de concentração viral. Em A, etapa de filtração, com suportes de filtros ligados em série. Em B, etapa de concentração, com sistema Prep Scale ${ }^{\circledR}$ - TFF da Millipore ${ }^{\circledR}$. Em detalhe, os dois fluxos de saída do cartucho (rosa): permeado (amarelo) e retido (azul), onde o fluxo permeado, livre de partículas virais, é eliminado e o fluxo retido, contendo as partículas virais, reabastece o sistema.

Os concentrados virais obtidos foram armazenados a $4{ }^{\circ} \mathrm{C}$ e transportados para o laboratório em São Paulo, onde foram reconcentrados por ultracentrifugação a $100.000 \mathrm{xg}$ por 2 horas a $4 \stackrel{\circ}{\circ} \mathrm{C}$, perfazendo um fator de concentração de 1000 vezes para todas as amostras. Ou seja, 
independentemente do volume inicial de amostra, após o processo de ultracentrifugação, o volume final foi 1000 vezes menor que o inicial. O material foi então armazenado a $4{ }^{\circ} \mathrm{C}$ até $\mathrm{o}$ momento de uso para as análises moleculares.

\subsection{Cálculo da eficiência da concentração}

O cálculo da eficiência da concentração segue a fórmula:

$$
(\mathrm{Ci}-\mathrm{Cf}) \times 100 / \mathrm{Ci}=\text { Eficiência, }
$$

onde Ci é a concentração de partículas virais na amostra pós-filtrada (inicial) e Cf é a concentração de partículas virais no CV (final). A fórmula assume a amostra pós-filtrada como inicial, uma vez que há uma perda de partículas para as membranas utilizadas na pré-filtragem.

As concentrações Ci e Cf são calculadas através do método de contagem direta proposto por Noble e Fuhrman (1998). Resumidamente, esse método consiste na preparação de lâminas com os filtros de 0,2 $\mu \mathrm{m}$ (Anodisc filter, Whatman) por onde foram filtrados $100 \mu \mathrm{l}$ a $200 \mu \mathrm{l}$ da amostra, corados com o corante de DNA, SYBR Green - I (Molecular Probes). A observação e contagem das partículas virais seriam realizadas com o uso de um microscópio de epifluorescência, com aumento de 1000 vezes, sob excitação de luz azul.

Também são feitas lâminas para a contagem de partículas virais com amostras de antes da pré-filtragem e do ultrafiltrado, no intuito de monitorar todas as possíveis perdas de partículas virais durante o processo.

\subsection{Análises moleculares}

\subsubsection{Purificação das amostras de água - Tratamento com Vertre ${ }^{\oplus}$}

O tratamento das amostras com Vertrel $\mathrm{XF}^{\circledR}(1,1,1,2,3,4,4,5,5,5,5,5$ decafluoropentano, DuPont ${ }^{\circledR}$ ) para a eliminação de gordura (Queiroz et al., 2001) foi realizado anteriormente à extração de DNA. Para isso, acrescentou-se a cada alíquota de amostra o mesmo volume de Vertrel $^{\circledR}$, homogeneizado em agitador mecânico por 5 minutos e centrifugado a $4.000 \mathrm{xg}$ por 10 minutos em centrífuga para microtubos Eppendorf ${ }^{\circledR}$. O sobrenadante foi então transferido para novo tubo e o procedimento foi repetido de uma a quatro vezes, até que a interface, gerada pelo processo, aparecesse limpa. As amostras tratadas foram estocadas a $-20 \stackrel{\circ}{\mathrm{C}}$ até o momento de uso.

\subsubsection{Extração de DNA das amostras de água}

O DNA das amostras foi extraído com o kit para extração de DNA de amostras de solo, PowerSoil DNA $\left(\mathrm{MoBio}^{\circledR}\right)$, segundo instruções do fabricante.

\subsubsection{Amplificação do DNA viral}

Todas as reações de $P C R$ foram realizadas no termociclador Hybaid PCR Express e tiveram como controle negativo mistura contendo todos os reagentes, exceto a amostra de DNA, substituída por água MilliQ. 
A visualização dos produtos amplificados foi realizada através de eletroforese em gel contendo 1,5\% de agarose, em tampão 0,5 X TBE (0,045 M Tris-borato, $1 \mathrm{mM}$ EDTA [pH 8,0]), submetido a $100 \mathrm{~V}$ por aproximadamente uma hora, corado com SYBR Gold (Invitrogen), e visualizado sob luz UV.

\subsubsection{PCR para ficodnavírus}

Na busca por vírus da família Phycodnaviridae, foram utilizados os oligonucleotídeos AVS-1 e AVS-2, os quais amplificam fragmento de aproximadamente $700 \mathrm{pb}$ da DNA polimerase de alguns vírus da família Phycodnaviridae (Chen e Suttle, 1995) (Figura 13). Como controle positivo, utilizou-se $D N A$ purificado do vírus $M p V$.

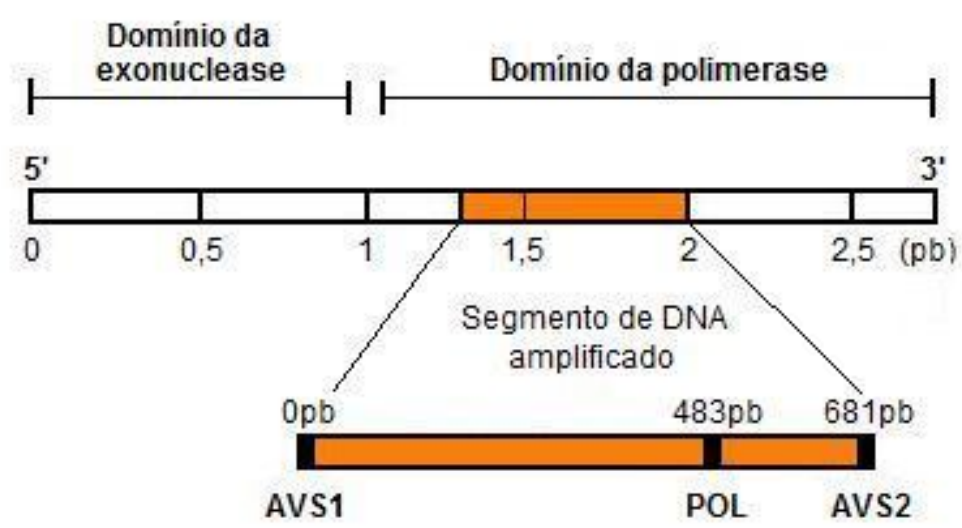

Figura 13. Mapa genérico do gene da DNA polimerase da família $\mathrm{B}(\alpha$-like), mostrando as regiões conservadas e suas possíveis funções. Em laranja, região amplificada pelos oligonucleotídeos AVS-1 e AVS-2 e o oligonucleotídeo interno POL.

Fonte: Modificado de Chen e Suttle (1995).

A amplificação das sequências de ficodnavírus foi realizada a partir de $100 \mathrm{ng}$ de $D N A$, adicionados a uma mistura contendo $1 \mathrm{U}$ de PLATINUM $^{\circledR}$ Taq DNA polimerase (Invitrogen), tampão de reação (200 mM Tris- $\mathrm{HCl}[\mathrm{pH}$ 8,4], $500 \mathrm{mM} \mathrm{KCl,} 3 \mathrm{mM} \mathrm{MgCl}$ ), 0,2 mM de mistura de dNTP, 10 pmoles do oligonucleotídeo AVS-1 e 30 pmoles do AVS-2, em água MilliQ, com volume final de 50 $\mu \mathrm{L}$.

O programa de amplificação constou de etapa de denaturação inicial de 90 s a $95^{\circ} \mathrm{C}$, seguida de 40 ciclos de denaturação a $95^{\circ} \mathrm{C}$ (45s), anelamento a $45^{\circ} \mathrm{C}$ (45s) e extensão a $72{ }^{\circ} \mathrm{C}(45 \mathrm{~s})$, e etapa de extensão final de $15 \mathrm{~min}$ a $72^{\circ} \mathrm{C}$.

A reamplificação do DNA dos ficodnavírus com os oligonucleotídeos AVS-1 e AVS-2 foi realizada a partir dos fragmentos de $700 \mathrm{pb}$, amplificados com o mesmo par de oligonucleotídeos, e purificados do gel de agarose com o MinElute PCR Purification kit (Qiagen), segundo instruções do 
fabricante. As reações seguiram o protocolo da amplificação, com a diminuição do número de ciclos para 30.

A nested PCR com os oligonucleotídeos AVS-1 e POL (Chen e Suttle, 1995) foi realizada a partir de $100 \mathrm{ng}$ de $D N A$, adicionados a $25 \mu \mathrm{L}$ da mistura contendo $0,625 \mathrm{U}$ de PLATINUM ${ }^{\circledR}$ Taq DNA polimerase (Invitrogen), tampão de reação (200 mM Tris- $\mathrm{HCl}$ [pH 8.4], $500 \mathrm{mM} \mathrm{KCl,} 1,5 \mathrm{mM} \mathrm{MgCl}$ ), $0,16 \mathrm{mM}$ da mistura de dNTP e 30 pmoles de cada oligonucleotídeo.

O programa para a nested PCR constou de etapa de denaturação inicial de 90 s a $95^{\circ} \mathrm{C}$, seguida de 30 ciclos de denaturação a $95^{\circ} \mathrm{C}(30 \mathrm{~s})$, anelamento a $50^{\circ} \mathrm{C}(45 \mathrm{~s})$ e extensão a $72{ }^{\circ} \mathrm{C}$ (30s), e etapa de extensão final de $10 \mathrm{~min}$ a $72^{\circ} \mathrm{C}$.

Em ambos os casos, como controle positivo, também se utilizou DNA purificado do vírus $M p V$.

\subsubsection{PCR para miofagos}

Na busca de vírus da família Myoviridae, o primeiro par de oligonucleotídeos utilizado foi o CPS4-GC e CPS-9, o qual amplifica fragmento de aproximadamente 600 pb do gene da proteína g20 de cianofagos ${ }^{1}$ (comunicação informal).

A amplificação das sequências de miofagos foi realizada a partir de $100 \mathrm{ng}$ de $D N A$, adicionados a uma mistura contendo $1 \mathrm{U}$ de $\operatorname{PLATINUM}^{\circledR}$ Taq DNA polimerase (Invitrogen), tampão de reação (200 mM Tris- $\mathrm{HCl}[\mathrm{pH} 8,4], 500 \mathrm{mM} \mathrm{KCl}, 3 \mathrm{mM} \mathrm{MgCl}$ ), 0,2 mM de mistura de dNTP, 6 pmoles de cada oligonucleotídeo, em água MilliQ, com volume final de $50 \mu \mathrm{L}$.

O programa de amplificação constou de etapa de denaturação inicial de 90 s a $94^{\circ} \mathrm{C}$, seguida de 40 ciclos de denaturação a $94^{\circ} \mathrm{C}(45 \mathrm{~s})$, anelamento a $60^{\circ} \mathrm{C}(60 \mathrm{~s})$ e extensão a $72{ }^{\circ} \mathrm{C}(60 \mathrm{~s})$, e etapa de extensão final de $5 \min$ a $72^{\circ} \mathrm{C}$.

$\mathrm{Na}$ segunda bateria de testes para amplificar miofagos, foram utilizados os oligonucleotídeos CPS-1 e CPS-2 (Fuller et al., 1998), CPS-1 e CPS-8 (Zhong et al., 2002), e AN15 MCPF5 e AN15 MCPR5 (Baker et al., 2006), que amplificam fragmento de aproximadamente 165 pb e 592 pb do gene da proteína gp20 de cianomiofagos, e fragmento de 350 pb do gene da major capsid protein de cianomiofagos, respectivamente. As amplificações das amostras foram efetuadas a partir de $100 \mathrm{ng}$ de $D N A$, seguindo as condições estabelecidas nas referências citadas acima.

O último par de oligonucleotídeos testado para amplificar miofagos foi o MZIA-1bis e MZIA-6 (Filée et al., 2005), o qual tem como alvo região do gene estrutural gp23 que codifica para a major capsid protein de fagos T4-like, arquétipo da família Myoviridae, e que gera fragmentos de aproximadamente $550 \mathrm{pb}$.

\footnotetext{
${ }^{1}$ Dado não publicado; sequência gentilmente cedida pelo Dr. Curtis A. Suttle.
} 
A amplificação das sequências gênicas de miofagos foi realizada a partir de $100 \mathrm{ng}$ de $D N A$, adicionados a uma mistura contendo 0,5 U de PLATINUM ${ }^{\circledR}$ Taq DNA polimerase (Invitrogen), tampão de reação (200 mM Tris- $\mathrm{HCl}$ [pH 8,4], $500 \mathrm{mM} \mathrm{KCl,} \mathrm{1,5} \mathrm{mM} \mathrm{MgCl}$ ), 0,2 mM de mistura de dNTP e 20 pmoles de cada oligonucleotídeo (MZIA-1bis e MZIA-6), em água MilliQ, com volume final de $50 \mu \mathrm{L}$.

O programa de amplificação constou de etapa de denaturação inicial de 90 s a $95^{\circ} \mathrm{C}$, seguida de 30 ciclos de denaturação a $95^{\circ} \mathrm{C}(45 \mathrm{~s})$, anelamento a $50^{\circ} \mathrm{C}(60 \mathrm{~s})$ e extensão a $72{ }^{\circ} \mathrm{C}(45 \mathrm{~s})$, e etapa de extensão final de $10 \mathrm{~min}$ a $72^{\circ} \mathrm{C}$.

Como controle positivo, em todas as reações acima descritas, utilizou-se DNA purificado do vírus S-pwm1 (fago de Synechococcus).

As reações de reamplificação do $D N A$ viral foram realizadas a partir dos fragmentos de 550 pb, amplificados com os oligonucleotídeos MZIA-1bis e MZIA-6, e purificados do gel de agarose com o MinElute PCR Purification kit (Qiagen), segundo instruções do fabricante. O protocolo utilizado foi o mesmo descrito para a amplificação, apenas com a redução do número de ciclos para 25 e com a substituição do oligonucleotídeo MZIA-1bis pelo MZIA-1bis-GC (oligonucleotídeo MZIA-1bis acrescido de grampo de guanina e citosina).

\subsubsection{Eliminação das células bacterianas por filtração}

Anteriormente à extração do DNA (protocolo descrito no item 4.8.2), alíquotas de $2 \mathrm{~mL}$ de concentrado viral foram filtradas através de filtro do tipo PVDF (fluoreto de polivinilideno) (Millipore) de porosidade $0,22 \mu \mathrm{m}$.

\subsubsection{Análise da estrutura das comunidades virais por DGGE (Denaturing Gradient Gel Electrophoresis)}

A aplicação do DGGE seguiu o protocolo preconizado por Short e Suttle (2000).

Aproximadamente $15 \mu \mathrm{g}$ de cada produto reamplificado (item 4.8.3) foram utilizadas para análise pelo método de DGGE. As eletroforeses foram conduzidas por 20 horas a $60^{\circ} \mathrm{C}$, em tampão TAE 1X (40 mM Tris-base, $20 \mathrm{mM}$ acetato de sódio, $1 \mathrm{mM}$ EDTA, pH 8,5), sob corrente de $60 \mathrm{~V}$, no sistema de eletroforese D-Code ${ }^{\circledR}$ da Bio-Rad (Short e Suttle, 2003). Os géis foram corados com SYBR Green (Invitrogen) e visualizados sob iluminação UV.

Para a análise do perfil da comunidade de ficodnavírus, foi realizada uma série de géis que continham $6 \%$ de bis-acrilamida e gradientes denaturantes (formamida e uréia) variando de $20 \%$ a $40 \%$, de $15 \%$ a $65 \%$, e de $25 \%$ a $35 \%$. Os géis para análise do perfil da comunidade de miofagos continham $6 \%$ de bis-acrilamida e gradiente denaturante (formamida e uréia) variando de $15 \%$ a $65 \%$. 


\subsubsection{Construção de biblioteca gênica a partir dos fragmentos do gel de DGGE}

Para a construção da biblioteca gênica a partir dos fragmentos do gel de DGGE, utilizou-se o $P C R^{\circledR} 4-T O P O^{\circledR}$ Cloning Kit for Sequencing (Invitrogen).

Fragmentos dos diferentes géis de DGGE foram retirados e colocados microtubos contendo $20 \mu \mathrm{L}$ de água MilliQ, por 12 horas, a $4{ }^{\circ} \mathrm{C}$, para a eluição do DNA. À partir do $D N A$ eluído, as sequências nucleotídicas foram reamplificadas de acordo com as condições e ciclos descritos no item 4.8.3, purificadas com o MinElute PCR Purification Kit (Qiagen), segundo instruções do fabricante, e clonadas no vetor plasmidial $P C R^{\circledR} 4-\mathrm{TOPO}^{\circledR}$. O plasmídio contendo inserto foi transfectado em bactérias $E$. coli quimiocompetentes, cultivadas em meio seletivo para ampicilina ( $100 \mu \mathrm{g} / \mathrm{mL}$ ).

Todos os procedimentos (purificação, clonagem e transfecção) foram realizados segundo instruções do fabricante do kit de clonagem utilizado.

\subsubsection{Construção de biblioteca gênica a partir do produto de PCR}

Todas as clonagens foram realizadas com o $P C R^{\circledast} 4-T O P O^{\circledR}$ Cloning Kit for Sequencing (Invitrogen), a partir de produtos de $P C R$ purificados com o MinElute PCR Purification Kit (Qiagen). Em ambos os procedimentos, foram seguidas as instruções dos fabricantes, e o meio Luria-Bertani utilizado nas culturas bacterianas foi seletivos para ampicilina $(100 \mu \mathrm{g} / \mathrm{mL})$.

Para ficodnavírus, o DNA clonado foi o fragmento de $600 \mathrm{pb}$ da nested PCR com os oligonucleotídeos AVS-1 e POL (item 4.8.3.1), e para miofagos, o amplicon resultante da reamplificação das sequências nucleotídicas com os oligonucleotídeos MZIA-1bis-GC e MZIA-6 (item 4.8.3.2). Ambos foram purificados com MinElute PCR Purification Kit (Qiagen), segundo instruções do fabricante, anteriormente à clonagem.

\subsubsection{Verificação da eficiência de clonagem}

Com o objetivo de verificar a clonagem do inserto correto e posterior sequenciamento do mesmo, foram realizadas amplificações por $P C R$, a partir dos clones.

Em $25 \mu \mathrm{L}$ de mistura em água MilliQ contendo $0,1 \mathrm{U}$ de PLATINUM $^{\circledR}$ Taq DNA polimerase (Invitrogen), tampão de reação (200 mM Tris- $\mathrm{HCl}[\mathrm{pH} 8,4], 500 \mathrm{mM} \mathrm{KCl}, 2 \mathrm{mM} \mathrm{MgCl}$ ), 0,1 mM de mistura de dNTP, 20 pmoles de ambos os oligonucleotídeos, T3 e T7 (fornecidos pelo kit de clonagem - Invitrogen), adicionou-se uma colônia bacteriana escolhida ao acaso.

As reações foram realizadas no termociclador Hybaid PCR Express, com programa de amplificação que constou de etapa de denaturação inicial de $9 \mathrm{~min}$ e 30 s a $94^{\circ} \mathrm{C}$, seguida de 30 ciclos de denaturação a $94{ }^{\circ} \mathrm{C}(30 \mathrm{~s})$, anelamento a $50{ }^{\circ} \mathrm{C}(30 \mathrm{~s})$ e extensão a $72{ }^{\circ} \mathrm{C}(60 \mathrm{~s})$, e etapa de extensão final de $8 \min$ a $72^{\circ} \mathrm{C}$. 
A visualização dos produtos amplificados foi realizada através de eletroforese em gel contendo 1,5\% de agarose, em tampão 0,5 X TBE (0,045 M Tris-borato, $1 \mathrm{mM}$ EDTA [pH 8,0]), submetido a $100 \mathrm{~V}$ por aproximadamente uma hora, corado com SYBR Gold (Invitrogen) e visualizado sob luz UV.

\subsubsection{Sequenciamento}

O sequenciamento, quando realizado em pequena quantidade, como no caso de testes de procedimentos, por exemplo, foi realizado a partir de $200 \mathrm{ng}$ de DNA plasmidial em mistura com 5 pmoles do oligonucleotídeo T3 (fornecido pelo kit de clonagem) e $3 \mu \mathrm{L}$ de solução de BigDye v3.1 Terminator (Applied Biosystems), no sequenciador automático ABI Prism 377 (Applied Biosystems) do Michael Smith Laboratory da University of British Columbia, Canadá.

No caso das bibliotecas gênicas, os sequenciamentos foram realizados em larga escala, em placas e segundo outro procedimento. Em suma, colônias bacterianas selecionadas randomicamente foram incubadas em $80 \mu \mathrm{L}$ de meio Luria-Bertani seletivo para ampicilina (100 $\mu \mathrm{g} / \mathrm{mL})$, em placas de 96 poços, por 12 horas, a $37^{\circ} \mathrm{C}$. Após este período, $40 \mu \mathrm{L}$ de glicerol $60 \%$ foram adicionados a cada poço e as placas foram novamente incubadas por 1 hora a $37^{\circ} \mathrm{C}$, e em seguida armazenadas a - 80 ${ }^{\circ} \mathrm{C}$. Nessas condições, foram enviadas ao Genome Québec Innovation Centre na McGill University, para serem sequenciadas no 3730xI DNA Analyzer Systems da Applied Biosystems.

\subsection{Ficodnavírus}

\subsubsection{Reconstrução filogenética}

As sequências obtidas foram submetidas a uma análise de similaridade utilizando o programa BLAST versão 2.0 (Altschul et al., 1997), tendo como base de sequências as de ficodnavírus. Apenas foram aceitas, como sequência de ficodnavírus, as que apresentaram valores de Ev inferiores a $10^{-10}$. Essas sequências foram alinhadas utilizando os programas ClustalX (Thompson et al., 1997) e Codon Align (http://www.sinauer.com/hall2e/), e os ajustes finos e edições das sequências foram realizadas manualmente com o programa Se-Al (Rambaut, 1996).

As reconstruções filogenéticas foram realizadas através do método de Máxima Verossimilhança (MV), a partir do alinhamento múltiplo das sequências de aminoácidos. Tal alinhamento continha as sequências de clones amazônicos e de diversas localidades do mundo (ANEXO C), e sequências de vírus isolados (ANEXO D), representantes de todos os gêneros da família Phycodnaviridae - PBCV, CbV, PgV, EsV, EhV, HaV-1, MpV, mais os vírus OsV e BpV ainda não classificados. Após a definição das raízes das árvores obtidas, uma segunda reconstrução filogenética foi realizada, também utilizando $\mathrm{MV}$, a partir do mesmo alinhamento de aminoácidos, com a exclusão, entretanto, das sequências mais divergentes ( $H a V-1, E h V, E s V, P g V, C b V$ e PBCV). 
A inferência filogenética foi executada no programa PhyML v2.4.4 (Guindon e Gascuel, 2003), utilizando o modelo de substituições de aminoácidos JTT, com os parâmetros: (i) proporção de sítios invariáveis, (ii) topologia de árvore, e (iii) parâmetro da forma da distribuição gama (alfa) para taxas de substituições estimadas dos dados.

As análises filogenéticas baseadas nas sequências de DNA foram realizadas com os mesmos dados, utilizando o pacote de programas BEAST versão 1.4.8. (Drummond e Rambaut, 2007).

As árvores de credibilidade máxima de clado, resumindo a probabilidade posterior dos nós da filogenia, foram obtidas pela visita por Monte Carlo, via cadeia de Markov (MCMC), em fase estacionária, a uma grande quantidade de árvores do universo amostral.

\subsubsection{Filodinâmica}

Para a investigação da história das populações de ficodnavírus, as sequências mais proximamente relacionadas foram subdivididas em demes e analisadas utilizando o método Bayesiano MCMC, implementado no pacote de programas BEAST versão 1.4.8. (Drummond e Rambaut, 2007).

A taxa de mutação anual por sítio ( $\mathrm{s} / \mathrm{s} / \mathrm{y}$, do inglês substitutions per site per year) dos ficodnavírus foi estimada através da interpolação do tamanho dos genomas dos ficodnavírus (160 Kb a $560 \mathrm{~Kb}$ ) na curva de taxa de mutação por sítio versus tamanho de genoma, de organismos variando de viroides a eucariotos superiores, apresentada por Gago et al. (2009).

Aplicou-se um relógio molecular, utilizando log-normal não correlacionada, com forte distribuição normal, assumindo, a priori, a média $=1,4^{-8} \mathrm{~s} / \mathrm{s} / \mathrm{y}$ e desvio padrão $=2,34^{-8} \mathrm{~s} / \mathrm{s} / \mathrm{y}$, uma vez que as datas de coleta das amostras não seriam infomativas nessa escala temporal. Para ser o mais conservativo possível, o least constrained Bayesian skyline coalescent prior foi aplicado no modelo melhor ajustado de substituição nucleotídica $(\mathrm{HKY}+\Gamma+\mathrm{l})$ (Shapiro et al., 2006).

Para melhorar a busca no método de MCMC, os valores dos operadores foram determinados como sendo uma função do número de táxons em cada grupo. Após a otimização os valores dos operadores de MCMC durante as corridas preliminares, foram realizadas até 10 corridas individuais adicionais, cada uma consistindo em 20 milhões de gerações (com 50\% burnin), a fim de se obter a convergência dos parâmetros estimadores. Em todas as análises, a convergência dos parâmetros, durante o método de MCMC, foi inspecionada com o programa Tracer versão 1.4. (Drummond e Rambaut, 2007), com as incertezas representadas como 95\% do intervalo de mais alta probabilidade $(H P D)$. Para a obtenção de uma avaliação independente da robustez da análise de dinâmica evolutiva realizada, o tempo até o ancestral comum mais recente (TMRCA) de cada conjunto de dados também foi estimado empregando o programa Path-O-Gen (http://tree.bio.ed.ac.uk/software/pathogen/), o qual utiliza uma regressão linear das distâncias genéticas root-to-tip contra o tempo de amostragem, sobre a filogenia por MV, descrita no item 4.9.1. 


\subsubsection{Migração de ficodnavírus entre ambientes aquáticos}

O programa BayesTraits (Pagel e Meade, 2004) foi utilizado para a obtenção das distribuições posteriores e das estimativas das análises de MV dos valores dos táxons de variação entre estados, as quais foram assumidas como sendo as estimativas da probabilidade posterior de ambas as taxas de movimentação (ex. migração) entre os três ambientes (lêntico, lótico e marinho), e a probabilidade posterior do estado na raiz das árvores (ex. origem dos vírus).

As análises foram realizadas usando 10.000 árvores para todas as sequências amostradas, depois que o método de MCMC alcançou estacionaridade (normalmente após 20 milhões de estados), e cada táxon foi identificado como sendo um estado multidiscreto representando sua origem ambiental (rio $=R$, lago $=L$, mar $=M$ ). Várias amostras de água doce cuja origem não pode ser definida como rio nem lago foram identificadas com os caracteres $\mathrm{R} L$ (rio ou lago). Estados faltantes foram identificados por hífens. Para melhorar as estimativas de convergência, foram realizadas 100 tentativas em achar a verissimilhança para cada árvore (mltries $=100$ ), com o programa BayesTrait.

\subsection{Miofagos}

\subsubsection{Reconstrução filogenética}

Todas as etapas da reconstrução filogenética de miofagos seguiram os mesmos métodos e parâmetros aplicados para a análise das sequências de ficodnavírus, como descrito no item 4.9.1.

O alinhamento utilizado continha as sequências de clones amazônicos e de diversas localidades do mundo (ANEXO E) e sequências de fagos isolados de bactérias (ANEXO F) dos gêneros Synechococcus (S-PM2), Procholococcus (P-SSM2 e P-SSM4), Vibrio (KVP40), Aeromonas (44RR2.8t) e Enterobacteria (T4, SJ98, RB32, RB49, RB69 e Phi1).

\subsection{Análise da morfologia viral por Microscopia Eletrônica de Transmissão (MET)}

A caracterização morfológica dos vírus foi realizada por MET através da técnica de coloração negativa (Kisielius, 1998).

Telas de cobre de 200 mesh (Electron Microscopy Sciences) foram revestidas com filme de solução de parlodion 2\% (Formvar) (Electron Microscopy Sciences) e colocadas sobre uma gota de $40 \mu \mathrm{L}$ de amostra, incubadas por 10 minutos a $4 \stackrel{\circ}{ } \mathrm{C}$. Após incubação, as telas foram colocadas sobre pedaço de papel filtro para secagem. Em seguida, as telas foram colocadas sobre uma gota de $20 \mu \mathrm{L}$ de solução corante de ácido fosfotúngstico $\left(\right.$ Sigma $^{\circledR}$ ) a 2\%, pH 6,4, por 1 minuto. Após repetição da incubação no corante, as telas foram colocadas sobre papel-filtro para secagem e armazenadas a temperatura ambiente até o momento da observação. 
As grades preparadas foram examinadas em um microscópio eletrônico JEOL JEM-1011 do departamento de Virologia do Instituto Adolfo Lutz, operado a $60 \mathrm{KV}$, e as imagens foram registradas com uma câmera CCD com magnificação de 50.000 e 100.000 vezes. 


\section{RESULTADOS E DISCUSSÃO}

\subsection{Coleta e processamento das amostras}

O desenho amostral inicial previa a coleta de um total de $200 \mathrm{~L}$ de água para cada amostra, resultado da soma de aproximadamente $65 \mathrm{~L}$ de cada ponto (margens direita e esquerda e centro do canal). A decisão sobre o volume, assim como tamanho e tipo de filtros a serem utilizados na filtração foi baseada nos resultados de um projeto-piloto realizado com amostras da represa do Guarapiranga, em São Paulo / SP (Gimenes et al., 2006), e em publicações que descreviam trabalhos semelhantes em ambiente marinho (Suttle et al., 1991; Chen et al., 1996), uma vez que não havia dados na literatura deste tipo de procedimento com amostras da região de Manaus.

Entretanto, durante o processamento da primeira amostra de cada rio, ficou constatada a impossibilidade de seguir com o protocolo de filtração proposto, devido à imensa quantidade de material particulado presente nas águas, especialmente do rio Solimões. As alterações, tanto em relação à adequação do volume a ser processado quanto à introdução do uso da membrana Whatman 40 antes da membrana de 1,2 $\mu \mathrm{m}$, foram tomadas no local, com o objetivo de viabilizar o processamento das amostras, mesmo que de maneira diferente da planejada. A possibilidade de grande perda de partículas virais no papel-filtro foi considerada, e o risco, assumido. Todas as membranas e papéis-filtro utilizados foram armazenados $\mathrm{a}-20^{\circ} \mathrm{C}$, no caso da necessidade ou interesse de análise. Também foi constatado que as membranas utilizadas, de $142 \mathrm{~mm}$ de diâmetro, não são as mais indicadas para o processamento de água da região amazônica, e sim as de maior superfície, com 293 mm de diâmetro.

A reavaliação da eficiência do processo de concentração não pôde ser realizada já que, durante o transporte de Manaus a São Paulo, as lâminas descongelaram, inviabilizando sua leitura para a contagem viral. Apesar disso, assumimos a eficácia do método - recuperação viral superior a 80\% (Suttle et al.,1991), uma vez que, desde sua descrição, o mesmo método tem sido empregado em diversos estudos de ambiente marinho, como, por exemplo, no mecanismo e taxa de decaimento de vírus (Suttle e Chen, 1992), na fotorreativação viral (Weinbauer et al., 1997), na abundância do virioplâncton (Wommack et al., 1999a) e na dinâmica populacional do grupo (Wommack et al., 1999b), além de em estudos sobre grupos específicos, como bacteriófagos (Filée et al., 2005; Short e Suttle, 2005), vírus de RNA (Culley et al., 2007), podovírus (Labonté et al., 2009), cianofagos (Chénard e Suttle, 2008) e vírus algais (Chen e Suttle, 1995; Chen et al., 1996; Clasen e Suttle 2009). Recentemente, o método também foi aplicado na pesquisa por vírus herpes, que infectam carpas e peixes-koi em ambientes de água doce (Honjo et al., 2010). Em 1996, o método de concentração viral proposto por Suttle et al. em 1991 foi modificado, apesar de baseado no mesmo princípio, e continuou a ser amplamente utilizado com sucesso em diversos trabalhos sobre a microbiota aquática (Short e Suttle, 2002; Zhong et al., 2002; Kan et al., 2005; Short e Suttle, 2005; Winget e Wommack, 2008; Zhang e Jiao, 2009). 


\subsection{Caracterização física e química das águas}

Dados físicos e químicos das amostras de água estudadas foram obtidos para caracterização dos corpos d'água no momento da coleta. Os valores de oxigênio dissolvido (OD) encontrados nas amostras variaram entre o valor mínimo de $2,73 \mathrm{mg} / \mathrm{L}$ no rio Negro (amostra NEGJ-1) e o máximo de $3,23 \mathrm{mg} / \mathrm{L}$, também no rio Negro (amostra NEGM-3) (Tabela 2). Tais valores são julgados baixos, uma vez que um rio considerado limpo, em condições normais, apresenta normalmente, de 3,5 mg a 8 mg de oxigênio dissolvido por litro (Cunha e Pascolaoto, 2006).

Tabela 2 - Caracterização química e física das amostras de água dos rios Cuieiras (CUI), Negro (NEGM e NEGJ) e Solimões (SOL).

\begin{tabular}{|c|c|c|c|c|c|}
\hline Amostra & $\begin{array}{l}\text { Data da } \\
\text { coleta }\end{array}$ & $\begin{array}{l}O D^{1} \\
(\mathrm{mg} / \mathrm{L})\end{array}$ & $\begin{array}{c}\mathrm{DBO}^{2} \\
(\mathrm{mg} / \mathrm{L})\end{array}$ & $\begin{array}{c}\text { Temperatura } \\
\left({ }^{\circ} \mathrm{C}\right)\end{array}$ & $\mathrm{pH}$ \\
\hline CUI-1 & $24 / 07 / 2007$ & 3,06 & 0,73 & 27,8 & 4,0 \\
\hline NEGM-1 & 17/07/2007 & 3,21 & 0,25 & 28,7 & 4,7 \\
\hline NEGM-2 & $20 / 07 / 2007$ & 3,21 & 0,13 & 28,3 & 4,5 \\
\hline NEGM-3 & $25 / 07 / 2007$ & 3,23 & n.d. & 28,6 & 4,2 \\
\hline NEGJ-1 & 19/07/2007 & 2,73 & 0,29 & 28,7 & 4,8 \\
\hline SOL-1 & $18 / 07 / 2007$ & 2,86 & 0,69 & 27,8 & 6,5 \\
\hline SOL-2 & $23 / 07 / 2007$ & 2,74 & 0,38 & 27,9 & 6,2 \\
\hline SOL-3 & $26 / 07 / 2007$ & 3,01 & 0,42 & 27,9 & 6,0 \\
\hline $\begin{array}{l}\text { CONAMA }^{3} \\
\text { classe } 1\end{array}$ & n.d. & $\geq 6$ & $\leq 3$ & n.d. ${ }^{4}$ & 6,0 a 9,0 \\
\hline
\end{tabular}

A baixa concentração de OD encontrada nas amostras pode ser resultado de três fatores: das altas temperaturas, do ciclo diurno da concentração do gás dissolvido e da presença de grande quantidade de matéria orgânica dissolvida (MOD) nos rios (Wetzel, 2001).

As altas temperaturas amazônicas (Tabela 2) podem reduzir a concentração de OD, uma vez que a solubilidade do gás é não linearmente afetada pela temperatura, diminuindo consideravelmente em águas quentes (Wetzel, 2001). Segundo Wetzel (2001), a concentração de oxigênio dissolvido em rios sofre oscilação cíclica diária, como consequência da atividade fotossintética de algas, macrófitas aquáticas e ciabactérias. A partir do nascimento do sol, ocorre um enriquecimento de oxigênio nas águas, que permanece em curva ascendente até poucas horas antes de o sol se pôr, quando a intensidade da luz solar começa a diminuir. A partir de então, a taxa de fotossíntese diminui até o cessamento completo e, durante o período da noite, ocorre apenas o consumo do oxigênio dissolvido na água. Assim, espera-se que maiores quantidades de oxigênio dissolvido por litro sejam 
constatadas nas últimas horas do dia. Entretanto, todas as amostras estudadas foram coletadas no período da manhã.

A grande quantidade de MOD nos rios amazônicos é resultado de aporte terrestre, lixiviado para o leito do rio durante o período de chuvas. Na época em que as amostras foram coletadas (julho), os rios estavam com seu volume máximo (período que antecede o início da vazante) e, portanto, as águas, com o maior tempo de residência nos rios. O processo de decomposição (oxidação) dessa matéria orgânica por micro-organismos envolve o consumo de oxigênio, resultando na diminuição da concentração do gás dissolvido na água. À farta disponibilidade de MOD nos rios, acrescentam-se as altas temperaturas características da região, que favorecem ainda mais os processos de decomposição. O consumo de oxigênio nos rios também pode ser resultado da oxidação fotoquímica de MOD e de substâncias húmicas (Wetzel, 2001), bastante abundantes no rio Negro (Cunha e Pascolaoto, 2006).

Cabe ressaltar que valores semelhantes de OD foram obtidos em todas as amostras do rio Negro, à exceção da amostra NEGJ-1, a qual apresentou uma redução de aproximadamente $20 \%$ no valor de OD. Essa amostra foi coletada na região de Educandos, localizada à margem esquerda do rio Negro, à jusante de Manaus, onde há uma fonte de poluição pontual, decorrente do lançamento dos efluentes domésticos não tratados da cidade. Como já mencionado anteriormente, com o maior aporte de matéria orgânica, há maior consumo de oxigênio para sua oxidação.

A medida do potencial hidrogeniônico $(\mathrm{pH})$ é usada para expressar o grau de acidez ou basicidade da água, ou seja, a concentração de íons de hidrogênio. Os baixos valores de $\mathrm{pH}$ encontrados nos rios Cuieiras ( $\mathrm{pH} \mathrm{4,0)}$ e Negro ( $\mathrm{pH} \mathrm{4,2)} \mathrm{(Tabela} \mathrm{2)} \mathrm{são} \mathrm{resultado} \mathrm{da} \mathrm{elevada}$ quantidade de substâncias húmicas (SHs) em ambos os rios (Cunha e Pascolaoto, 2006). Estas, por sua vez, têm importantes implicâncias na ecologia dos dois rios, principalmente sobre as comunidades fito e zooplanctônicas, que são a base da cadeia alimentar.

Primeiramente, SHs afetam o fitoplâncton física e quimicamente. Fisicamente, tais substâncias competem com o fitoplâncton por luz, uma vez que ambos - o carbono orgânico dissolvido cromofórico (CODC) das SHs e os pigmentos algais - absorvem luz. Quimicamente, SHs podem alterar a biodisponibilidade de nutrientes e micropoluentes para o fitoplâncton (Steinberg, 2003). O zooplâncton também é afetado por altas concentrações de SHs. Em águas ricas em SHs, organismos zooplanctônicos necessitam de carbono orgânico dissolvido alóctone (CODA) como fonte suplementar de alimento. O CODA é conseguido via cadeia alimentar por bactérias e ciliados ou pela absorção direta pelos crustáceos (Steinberg, 2003).

$\mathrm{Na}$ amostra NEGJ-1, esperávamos encontrar indicadores químicos da poluição pontual. Entretanto, isso não foi observado, uma vez que os valores de nitrito e nitrato encontraram-se dentro do estipulado pela resolução CONAMA 357/2005 para água de classe 1 (Tabela 3), e o valor de fosfato da amostra NEGJ-1, apesar de superior ao estipulado pela resolução, está apenas $0,01 \mathrm{mg} / \mathrm{L}$ 
(7\%) acima da amostra NEGM-1, coletada à montante de Manaus, e, portanto, anterior à fonte de poluição pontual.

Surpreendentemente, as amostras do rio Solimões apresentaram valores de fosfato expressivamente maiores que o estipulado pela resolução CONAMA 357/2005, especialmente porque o valor limite da resolução refere-se à quantidade de fósforo total e a quantidade avaliada foi apenas a de fosfato, a qual representa apenas uma fração do fósforo total (Tabela 3). Assim, os dados obtidos indicariam marcante poluição e alta eutrofização nas águas. Cabe ressaltar que a quantidade bastante elevada de fosfato observada nesse rio não pode ser imputada a problemas com o equipamento, uma vez que as medidas foram feitas em dias alternados com outros rios e os resultados mostraram-se sempre elevados, somente no rio Solimões e nas três estações de coleta. Apesar de não haver, na literatura, indicação de teores tão elevados de fósforo nessas águas, não foram observados indícios de fontes potencialmente poluidoras, tais como minas de exploração de rochas fosfáticas ou poluição de origem urbana, que pudessem explicar esses valores.

Como visto, utilizamos a resolução CONAMA 357/2005 como base para avaliação dos parâmetros químicos, por ser este o documento no qual o Ministério do Meio Ambiente dispõe sobre a classificação dos corpos de água e sobre as diretrizes ambientais para o seu enquadramento, fornecendo valores de referência para parâmetros físicos, químicos e biológicos.

Tabela 3 - Análise de ânions e cátions das amostras de água dos rios Cuieiras (CUI), Negro (NEGM e NEGJ) e Solimões (SOL).

\begin{tabular}{|c|c|c|c|c|}
\hline Amostra & $\begin{array}{c}\text { Data da } \\
\text { coleta }\end{array}$ & $\begin{array}{l}\text { Nitrito } \\
\text { (mg/L) }\end{array}$ & $\begin{array}{l}\text { Nitrato } \\
\text { (mg/L) }\end{array}$ & $\begin{array}{c}\text { Fosfato } \\
(\mathrm{mg} / \mathrm{L})\end{array}$ \\
\hline CUI-1 & $24 / 07 / 2007$ & n.d. ${ }^{1}$ & 0,021 & 0,054 \\
\hline NEGM-1 & $17 / 07 / 2007$ & 0,003 & 0,124 & 0,130 \\
\hline NEGM-2 & $20 / 07 / 2007$ & n.d. & 0,109 & 0,098 \\
\hline NEGM-3 & $25 / 07 / 2007$ & 0,001 & 0,127 & 0,058 \\
\hline NEGJ-1 & $19 / 07 / 2007$ & 0,007 & 0,140 & 0,140 \\
\hline SOL-1 & $18 / 07 / 2007$ & n.d. & 0,354 & 2,310 \\
\hline SOL-2 & 23/07/2007 & n.d. & 0,092 & 2,277 \\
\hline SOL-3 & $26 / 07 / 2007$ & n.d. & n.d. & 2,269 \\
\hline $\begin{array}{l}\text { CONAMA }^{2} \\
\text { Classe } 1\end{array}$ & n.a. ${ }^{3}$ & Até $1 \mathrm{mg} / \mathrm{L}$ & Até $10 \mathrm{mg} / \mathrm{L}$ & $\begin{array}{l}\text { Até } 0,1 \mathrm{mg} / \mathrm{L} \\
\text { de fósforo total }\end{array}$ \\
\hline
\end{tabular}

\footnotetext{
n.d. não detectável - valor inferior a 0,001

2 Resolução CONAMA 357/2005- padrões para água de classe 1

${ }^{3}$ n.a. dado não disponível
}

\subsection{Fitoplâncton}

A maior parte do fitoplâncton encontrada nos rios Solimões e Negro foi composta por diatomáceas (Bacillariophyta) (Tabela 4). A dominância do grupo em amostras amazônicas já era 
esperada por duas razões: primeiramente, por se tratar de ambiente lótico, com alta velocidade de corrente, a qual acaba por suprimir outros grupos menos resistentes (Wetzel, 2001); e, ainda, por essa dominância já ter sido relatada em diversos estudos realizados nos lagos Castanho (Uherkovich e Schmidt, 1974), Prato (Souza-Mosimann et al., 1997), Tupé (Melo et al., 2005) e Cutiuaú (Raupp et al., 2009), e nos rios Jaú (Diaz-Castro et al., 2003) e Negro (Uherkovich, 1976; Uherkovich e Raí, 1979).

Dentre as espécies de diatomáceas encontradas, a Aulacoseira granulata (Ehrenberg) Simonsen foi a dominante (Figura 14). Esse dado corrobora os apresentados por Uherkovich e Schmidt (1974), por Uherkovich (1976), por Uherkovich e Raí (1979), por Melo et al. (2005), e por Raupp et al. (2009), que verificaram a dominância de variantes da espécie Aulacoseira granulata em amostras amazônicas, fato que indica a presença dessa diatomácea na bacia Amazônia, em altas concentrações, há mais de três décadas.

As diatomáceas são bastante abundantes não somente em ambientes lóticos, como discutido anteriormente, mas também no ambiente marinho, onde são os organismos fotossintetizantes dominantes. Curiosamente, entretanto, apenas um número reduzido de vírus que infectam esse grupo foi descrito até o presente (Nagasaki et al., 2004; Nagasaki et al., 2005; Bettarel et al., 2005; Shirai et al., 2008), sendo que nenhum deles pertence à família Phycodnaviridae. O primeiro vírus de diatomácea descrito, o RsRNAV, foi isolado no Japão, e é um vírus de RNA simples fita que infecta a diatomácea marinha Rhizosolenia setigera (Nagasaki et al., 2004); o segundo foi o vírus de inclusão nuclear CsNIV, que possui uma molécula de DNA circular e um fragmento de DNA, ambos simples fita, e infecta a diatomácea Chaetoceros salsugineum Takano, a qual é encontrada em lagos e estuários (Nagasaki et al., 2005); o terceiro vírus, isolado nos Estados Unidos da América, foi outro de inclusão, o CspNIV, que infecta organismos de outra espécie marinha de Chaetoceros, a Chaetoceros cf. gracilis (Bettarel et al., 2005); o quarto é o vírus CtenRNAV01, que possui RNA simples fita e infecta diatomáceas da espécies Chaetoceros tenuissimus, também marinha (Shirai et al., 2008); e o quinto é o vírus CsfrRNAV, isolado na baia de Hiroshima, o qual infecta organismos da espécie Chaetoceros socialis Lauder f. radians (Schütt) Proschkina-Lavrenko (Tomaru et al., 2009). Cabe salientar que nenhuma das espécies de diatomáceas mencionadas acima foi encontrada nas amostras da região Amazônica e que todas são formadoras de florações. 


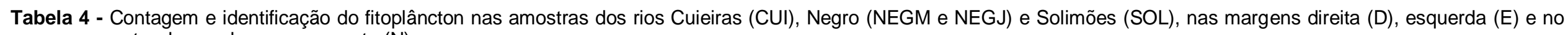
centro do canal, ou na nascente $(\mathrm{N})$.

\begin{tabular}{|c|c|c|c|c|c|c|c|c|c|c|c|c|c|c|c|c|c|}
\hline \multirow{3}{*}{ TÁXON } & \multicolumn{17}{|c|}{ AMOSTRAS (Ind./mL) } \\
\hline & \multirow{2}{*}{$\begin{array}{c}\text { CUl-1 } \\
N\end{array}$} & \multicolumn{3}{|c|}{ NEGM-1 } & \multicolumn{2}{|c|}{ NEGM-2 } & \multicolumn{3}{|c|}{ NEGM-3 } & \multirow{2}{*}{$\begin{array}{c}\text { NEGJ-1 } \\
\text { E }\end{array}$} & \multicolumn{3}{|c|}{ SOL-1 } & \multicolumn{3}{|c|}{ SOL-2 } & \multirow{2}{*}{$\begin{array}{c}\text { SOL-3 } \\
\text { E }\end{array}$} \\
\hline & & D & C & E & C & $\mathbf{E}$ & D & C & E & & D & C & E & D & C & E & \\
\hline \multicolumn{18}{|l|}{ Bacillariophyta (diatomáceas) } \\
\hline Amphora sp. & & & & & & & & & & & & 10,81 & & & & & \\
\hline Asterionella ralfsii W. Smith & & 13,21 & 186,17 & 26,42 & 10,81 & & 10,81 & & 74,59 & 13,21 & & 140,53 & 43,24 & 227,00 & 92,48 & 54,05 & 1866,46 \\
\hline Aulacoseira granulata (Ehrenberg) Simonsen & & 237,81 & 489,44 & 224,60 & 183,76 & 128,51 & 151,33 & 147,01 & 185,09 & 66,06 & 540,48 & 248,62 & 162,14 & 475,62 & 290,66 & 351,31 & 807,12 \\
\hline Diatomácea cêntrica & 85,28 & & 27,02 & & 21,62 & 10,81 & & 14,70 & 124,31 & & & & & & & & 223,40 \\
\hline Diatomácea penada & 21,62 & 13,21 & & & 43,24 & 37,23 & 64,86 & 44,10 & 325,97 & 13,21 & 270,24 & 10,81 & & 54,05 & & 81,07 & 482,83 \\
\hline Eunotia sp. & & & & & & & & & 30,39 & & & 10,81 & & & & & \\
\hline Fragilaria sp. & & & & 13,21 & & & & & 30,39 & & & & & & & & 79,27 \\
\hline Frustulia sp. & 74,47 & & & & & & & & 146,41 & & & & & & & & \\
\hline Navicula cf. cryptocephala Kützing & 56,45 & & & & & & & & & & & & & 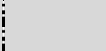 & & & \\
\hline Naviculaceae & 39,64 & & 27,02 & & 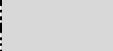 & 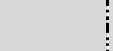 & & & & & & & & 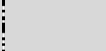 & & & ! \\
\hline Nitzschia sigma (Kützing) Wm. Smith & $13,21 !$ & & & & & & & & & & & & & & & & \\
\hline Nitzschia sp. & & & & & 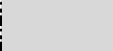 & & & & 24,86 & & & & 10,81 & & & & \\
\hline Nitzschia sp. 2 & & & & & & & & & 151,94 & & & & & & & & 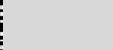 \\
\hline Tabellaria sp. & & & & & & & & & 24,86 & & & & & & & & \\
\hline \multicolumn{18}{|l|}{ Chlorophyta } \\
\hline Chlamydomonas sp. & & 13,21 & & & & & & & & & & & & & & & \\
\hline Desmodesmus sp. & 13,21 & & & & & & & & & & & & & $!$ & & & \\
\hline Cosmarium sp. & & & & & & & & & 24,86 & & & & & 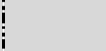 & & & \\
\hline Desmidium sp. & & & & & $\vdots$ & 10,81 & & & & & & & & 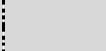 & & & \\
\hline Hyalotheca sp. & & & & & & & 10,81 & & & & & & & & & & 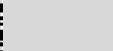 \\
\hline Mougeotia sp. & & 26,42 & 27,02 & & 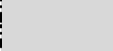 & & 21,62 & & 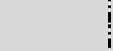 & & $i$ & 10,81 & & 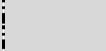 & & 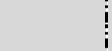 & \\
\hline Oedogonium sp. & & 13,21 & & & & & 10,81 & & & & & & & 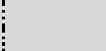 & & & 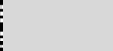 \\
\hline Spirogyra sp. & & 13,21 & & 39,64: & 10,81 & 24,02 & & 14,70 & & 13,21 & & & & ! & & & \\
\hline Zygnemaphyceae & & & & 13,21 & 10,81 & & & 14,70 & 24,86 & & & & & 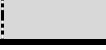 & & 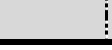 & \\
\hline
\end{tabular}




\section{(Conclusão)}

\begin{tabular}{|c|c|c|c|c|c|c|c|c|c|c|c|c|c|c|}
\hline \multicolumn{15}{|l|}{ Cyanophyta } \\
\hline Anabaena sp. & tan & & & & & $!$ & & & 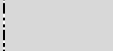 & & & 13,21 & & \\
\hline Geitlerinema sp. & thata & & & & 54,05 & 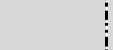 & 30,39 & & a & & & & & \\
\hline Komvophoron sp. & trat & & & & 10,81 & 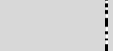 & 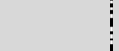 & & 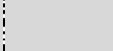 & 10,81 & & & 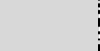 & \\
\hline Myxobaktron sp. & & & & & 10,81 & & & & $!$ & & & & & \\
\hline Oscillatoriales & & 13,21 & & & 21,62 & 43,24 & 270,72 & & & 10,81 & & 79,27 & 27,02 & 144,13 \\
\hline Phormidium sp. & 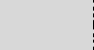 & & 54,05 & & 10,81 & 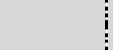 & 30,39 & & 270,24 & 10,81 & 32,43 & & 27,02 & \\
\hline Pseudanabaenasp. & & 13,21 & & & 10,81 & 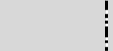 & & & & & 10,81 & & & \\
\hline Stigonemataceae & 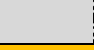 & & & & & 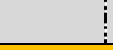 & : & & 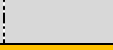 & & & & & 454,00 \\
\hline \multicolumn{15}{|l|}{ Myzozoa / Dinophyceae } \\
\hline Peridiniales & 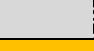 & & 27,02 & & & $i$ & & & $i$ & & 10,81 & & & 64,86 \\
\hline \multicolumn{15}{|l|}{ Euglenophyta } \\
\hline Euglena sp. & 13,21 & & 33,03 & & & & 24,86 & & & & 10,81 & & & \\
\hline Euglena sp. 1 & 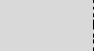 & & & & & 13,21 & & & & & & & & \\
\hline Euglena sp.2 & & & & & & 24,02 & & & & & & & & \\
\hline Lepocinclis acus (O. F. Müller) Marin et Melkonian & tan & & & 13,21 & & 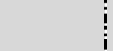 & & & 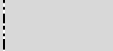 & & & & int & \\
\hline Phacus sp. & tan & & 27,02 & & & 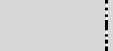 & 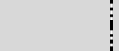 & & 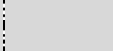 & & & & & \\
\hline Strombomonas SP & tan & & 27,02 & & & 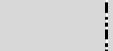 & & & 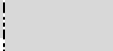 & & & & & \\
\hline Trachelomonas sp. & 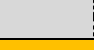 & & 27,02 & & & 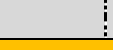 & & 13,21 & & 10,81 & & & & 64,86 \\
\hline \multicolumn{15}{|l|}{ Outros grupos } \\
\hline colônia algal & 26,42 & & & & 21,62 & & 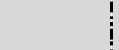 & & 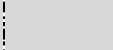 & & & & t & \\
\hline Fitoflagelado & 10,81 & & & & & 26,42 & 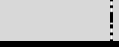 & 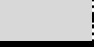 & 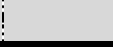 & & 10,81 & & - & \\
\hline
\end{tabular}




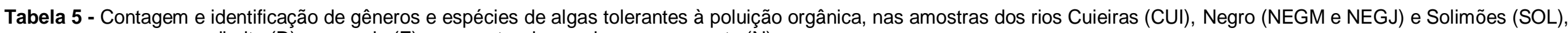
nas margens direita $(D)$, esquerda $(E)$ e no centro do canal, ou na nascente $(N)$.

\begin{tabular}{|c|c|c|c|c|c|c|c|c|c|c|c|c|c|c|c|c|c|}
\hline \multirow{3}{*}{ TÁXON } & \multicolumn{17}{|c|}{ AMOSTRAS (Ind./mL) } \\
\hline & \multirow{2}{*}{$\begin{array}{c}\text { CUl-1 } \\
\mathrm{N}\end{array}$} & \multicolumn{3}{|c|}{ NEGM-1 } & \multicolumn{2}{|c|}{ NEGM-2 } & \multicolumn{3}{|c|}{ NEGM-3 } & \multirow{2}{*}{$\begin{array}{c}\text { NEGJ-1 } \\
\text { E }\end{array}$} & \multicolumn{3}{|c|}{ SOL-1 } & \multicolumn{3}{|c|}{ SOL-2 } & \multirow{2}{*}{$\begin{array}{c}\text { SOL-3 } \\
\text { E }\end{array}$} \\
\hline & & D & C & E & C & 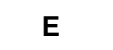 & D & C & E & & D & C & E & D & C & E & \\
\hline \multicolumn{18}{|l|}{ Bacillariophyta (diatomáceas) } \\
\hline Asterionella ralfsii W. Smith & & 13,21 & 186,17 & 26,42 & 10,81 & 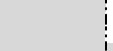 & 10,81 & & 74,59 & 13,21 & & 140,53 & 43,24 & 227,00 & 92,48 & 54,05 & 1866,46 \\
\hline Fragilaria sp. & 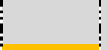 & & & 13,21 & & 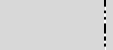 & & & 30,39 & & & & & & & & 79,27 \\
\hline Navicula cf. cryptocephala Kützing & 56,45 & & & & & 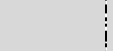 & & & & & & & & & & & 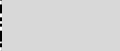 \\
\hline Naviculaceae & 39,64 & & 27,02 & 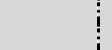 & & 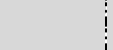 & & & 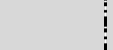 & & 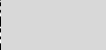 & & & 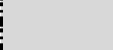 & & & 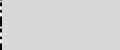 \\
\hline Nitzschia sigma (Kützing) Wm. Smith & 13,21 & & & 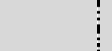 & & L & & & & & 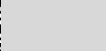 & & & & & & 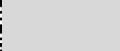 \\
\hline Nitzschia sp. & 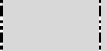 & & & 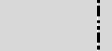 & & 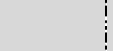 & & & 24,86 & & 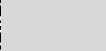 & & 10,81 & & & & 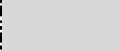 \\
\hline Nitzschia sp. 2 & 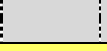 & & & 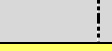 & & 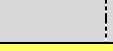 & & & 151,94 & & 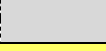 & & & & & & \\
\hline \multicolumn{18}{|l|}{ Chlorophyta } \\
\hline Chlamydomonas sp. & & 13,21 & & $\begin{array}{l}\vdots \\
\vdots \\
\vdots\end{array}$ & & 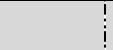 & & & & & 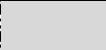 & & & 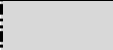 & & & 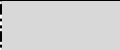 \\
\hline Cosmarium sp. & 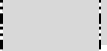 & & & $\vdots$ & & 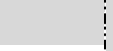 & & & 24,86 & & & & 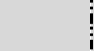 & 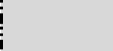 & & & 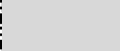 \\
\hline Spirogyra sp. & 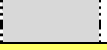 & 13,21 & & 39,64 & 10,81 & 24,02 & & 14,70 & & $13,21 !$ & & & 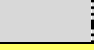 & 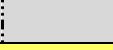 & & 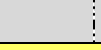 & \\
\hline \multicolumn{18}{|l|}{ Cyanophyta } \\
\hline Anabaena sp. & $\vdots$ & & & 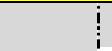 & & $i$ & & & & & & & & & 13,21 & & \\
\hline Oscillatoriales & $\vdots$ & 13,21 & & & 21,62 & 43,24 & & & 270,72 & & & & 10,81 & & 79,27 & 27,02 & 144,13 \\
\hline Phormidium sp. & 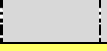 & & 54,05 & $\vdots$ & 10,81 & 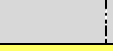 & & & 30,39 & & 270,24 & & 10,81 & 32,43 & & 27,02 & \\
\hline \multicolumn{18}{|l|}{ Euglenophyta } \\
\hline Euglena sp. & 13,21 & & 33,03 & & & & & & 24,86 & & & & & 10,81 & & & \\
\hline Euglena sp. 1 & & & & 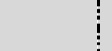 & & 13,21 & & & & & & & & & & & 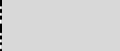 \\
\hline Euglena sp.2 & 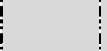 & & & 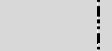 & & 24,02 & & & 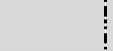 & & 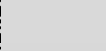 & & & 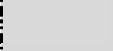 & & ! & 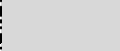 \\
\hline Phacus sp. & 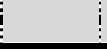 & & 27,02 & 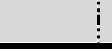 & & 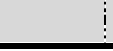 & & & ! & & 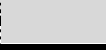 & & & 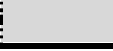 & & 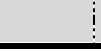 & 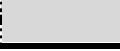 \\
\hline
\end{tabular}




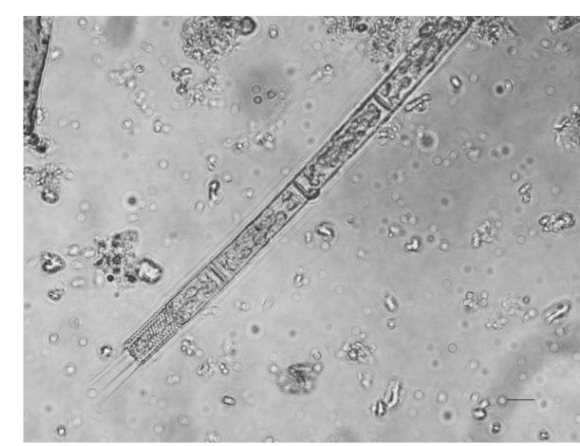

Figura 14. Aulacoseira granulata (Ehrenberg) Simonsen. Aumento de 40X.

Como já discutido, nenhum dos parâmetros químicos medidos evidenciou poluição por efluentes na amostra de Educandos (NEGJ-1). Entretanto, a contagem de células fitoplanctônicas e a riqueza do grupo (número de táxons encontrado) sofreram significativa redução nessa amostra, possivelmente como resultado da poluição pontual. A média do número de indivíduos por $\mathrm{mL}$ da espécie Aulacoseira granulata (Ehrenberg) Simonsen nas amostras do rio Negro, à montante de Manaus, foi de 317,28 ind./mL na NEGM-1, 156,13 ind./mL na NEGM-2 e 161,14 ind./mL na NEGM-3. Considerando o menor valor, obtido na amostra NEGM-3, a redução no número de indivíduos na amostra à jusante de Manaus foi de 57,7\%. Em termos de riqueza, dos 35 táxons encontrados nas amostras do rio Negro à montante de Manaus, apenas cinco estiveram presentes na amostra à jusante da cidade, e todos com um número reduzido de ind./mL.

Utilizando-se o índice de Palmer para a avaliação do grau de poluição do corpo d'água, verificou-se que, dos 60 gêneros de algas resistentes à poluição orgânica listados por Palmer (1969), apenas 12 foram encontrados nas amostras de Manaus (Tabela 5). Entretanto, para efeito do cálculo do índice, somente se considera a alga presente na amostra quando sua contagem é igual ou maior a 50 ind./mL, o que reduziu o número de gêneros para a metade. $O$ índice de Palmer para as amostras foi zero nas NEGM-2 e NEGJ-1, um nas NEGM-1 e SOL-1, três na CUI-1, 5 na SOL-2 e SOL-3 e oito na NEGM-3, não sendo indicativo de poluição orgânica em nenhuma das amostras avaliadas, uma vez que, para tanto, os índices teriam que ser maiores ou iguais a 15. Sendo assim, contrariamente ao sugerido pela redução da riqueza do fitoplâncton na amostra de Educandos, segundo o índice de Palmer, não há indicação de poluição orgânica na NEGJ-1.

Por fim, acreditamos que uma provável recuperação na riqueza da população fitoplanctônica do rio Negro e consequente eutrofização das águas deva acontecer mais adiante no curso do rio, uma vez que o acréscimo de nutrientes biodisponíveis para a multiplicação celular, decorrente do lançamento de efluentes nas águas, só ocorre após algum tempo, como resultado da oxidação da matéria orgânica lançada no rio (Wetzel, 2001). 


\subsection{Phycodnaviridae}

\subsubsection{Análise molecular}

O método de extração de $D N A$ utilizado foi o PowerSoil DNA kit $\left(\mathrm{MoBio}^{\circledR}\right)$, indicado para a extração de DNA de solo. A escolha desse kit deve-se ao fato de ser ele eficaz na remoção de substâncias húmicas, presentes em excesso nas águas do rio Negro.

Anteriormente à padronização do protocolo de extração de $D N A$, foi realizado um teste a partir de três diferentes tipos de amostra, para verificação do procedimento de extração de DNA mais eficiente - concentrado viral bruto, concentrado viral tratado com Vertrel ${ }^{\circledR}$ e a interface descartada durante o tratamento com Vertrel ${ }^{\circledR}$. Alíquotas do DNA obtido de uma amostra de cada rio (CUI-1, NEGM-1 e SOL-2), em cada um dos processos, foram submetidas à amplificação por $P C R$ com os oligonucleotídeos AVS-1 e AVS-2 para ficodnavírus.

Os resultados obtidos evidenciaram a presença de DNA na interface descartada no tratamento com Vertrel $^{\circledR}$, em quantidade suficiente para a amplificação por PCR (Figura 15). Consequentemente, a adoção desse procedimento no processo de extração de DNA acarretaria a perda significativa de material genético. Ao mesmo tempo, os dados mostraram que a extração de $D N A$ com o kit para extração de DNA de solo, sem tratamento prévio com Vertrel ${ }^{\circledR}$, foi eficaz na obtenção de DNA puro o suficiente para análises moleculares. Assim, optou-se pela não realização da etapa de purificação das amostras com Vertrel ${ }^{\circledR}$, procedendo-se a extração dos DNAs diretamente das amostras brutas, com o kit para extração de DNA de solo.

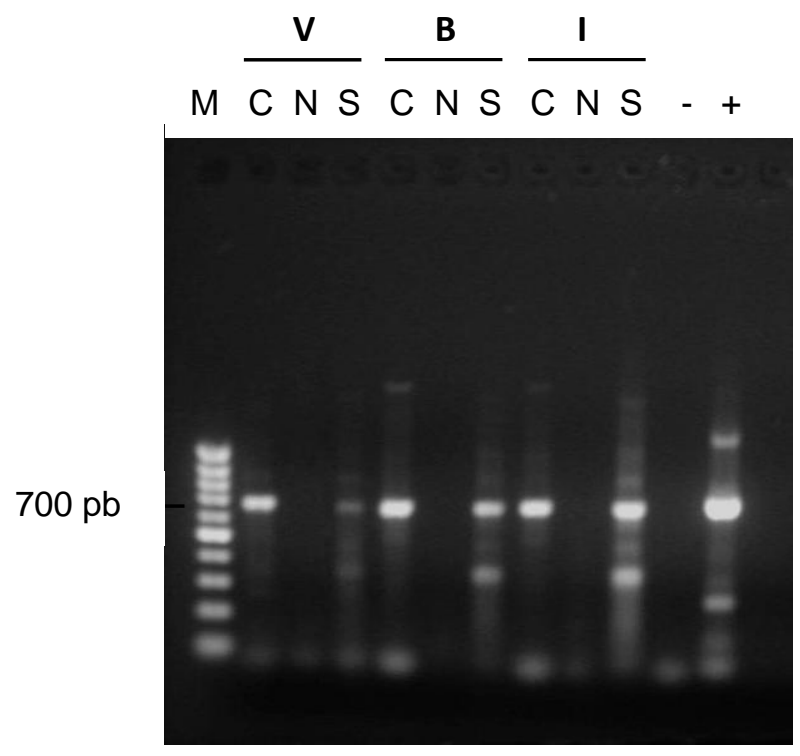

Figura 15. Teste de eficiência dos métodos de extração de DNA de ficodnavírus. Eletroforese em gel de agarose $(1,5 \%)$ de produtos de PCR amplificados a partir das amostras CUl-1 (C), NEGM-1 (N) e SOL-2 (S), dos rios Cuieiras, Negro e Solimões, respectivamente. DNA extraído com PowerSoil $D N A$ kit $\left(\mathrm{MoBio}^{\circledR}\right)$, a partir do material tratado com Vertrel ${ }^{\circledR}(\mathrm{V})$, do concentrado viral bruto (B), e da interface resultante do tratamento com Vertrel ${ }^{\circledR}$ (I). Amplificações realizadas com os oligonucleotídeos AVS-1 e AVS-2, para ficodnavírus. Controle negativo (-) com água e controle positivo (+) com DNA do vírus de Micromonas pusilla.Marcador de peso molecular de 100 pb (M). Gel corado com SYBR Green e visualizado sob luz UV. 
No mesmo experimento, verificou-se a presença de ficodnavírus nas amostras dos rios Cuieiras e Solimões, mas não na do rio Negro (Figura 15). Devido ao fato de este rio apresentar grande quantidade de SHs, e de estas substâncias serem conhecidamente inibidoras de PCR, levantamos a hipótese de ainda existir no DNA SHs em quantidade suficiente para inibir a amplificação do genoma viral, gerando um resultado falso-negativo.

Para testar a possível inibição da reação de $P C R$ por SHs, novas amplificações foram realizadas com a introdução de DNA do rio Negro (NEGM-1) na amostra do rio Cuieiras (CUI-1) e no controle positivo. Conforme mostra o gel da Figura 16, a hipótese foi refutada, uma vez que não foi constatada inibição na amplificação.

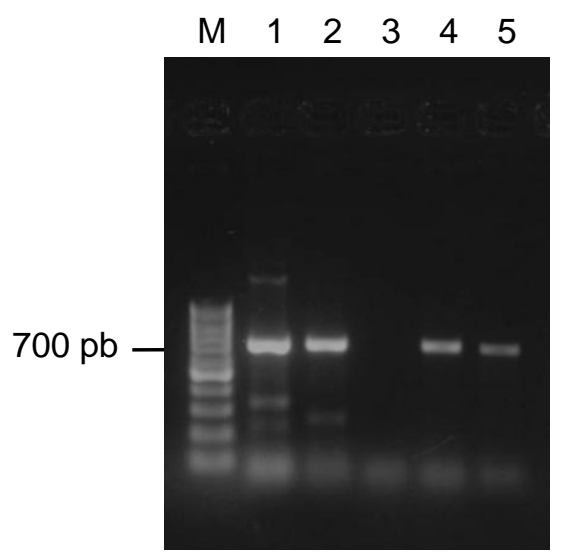

\author{
M: marcador de peso molecular \\ de $100 \mathrm{pb}$ \\ 1: controle positivo \\ 2: controle positivo com amostra \\ NEGM-1 \\ 3: controle negativo \\ 4: amostra CUI-1 \\ 5: amostra CUI-1 com amostra \\ NEGM-1
}

Figura 16. Teste de inibição da reação de $P C R$ por substâncias presentes no DNA extraído da amostra NEGM1. Eletroforese em gel de agarose $(1,5 \%)$ de produtos de $P C R$ amplificados a partir de DNA do vírus de Micromonas pusilla e da amostra CUI-1, com (2 e 5) e sem (1 e 4) adição de DNA da amostra NEGM-1. Amplificações realizadas com os oligonucleotídeos AVS-1 e AVS-2, para ficodnavírus. Controle negativo (3) com água e marcador de peso molecular de 100 pb. Gel corado com SYBR Green e visualizado sob luz UV.

Após os testes dos métodos de extração de $D N A$, foi realizada a extração do $D N A$ das amostras restantes (NEGM-2, NEGM-3, NEGJ-1, SOL-1 E SOL-3), seguida de PCR com oligonucleotídeos AVS para verificar se os resultados obtidos anteriormente e já apresentados seriam confirmados nas demais amostras. Como mostra a Figura 17, a não amplificação de ficodnavírus nas outras amostras do rio Negro se repetiu. A tentativa de reamplificação do produto de $P C R$ foi realizada para verificar se a não amplificação das amostras verificada na primeira reação seria resultado da pouca quantidade de produto amplificado. Entretanto, a reamplificação também não ocorreu. 


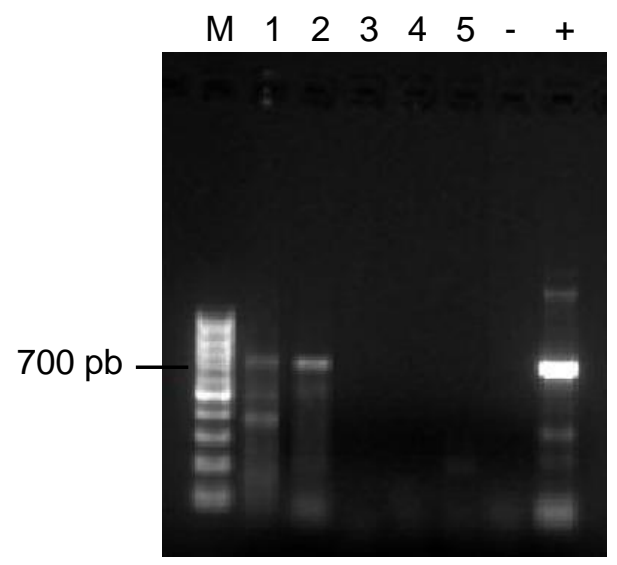

M: marcador de peso

molecular de $100 \mathrm{pb}$

1: amostra SOL-1

2: amostra SOL-3

3: amostra NEGM-2

4: amostra NEGM-3

5: amostra NEGJ-1

- : controle negativo

+ : controle positivo

Figura 17. Detecção de ficodnavírus em amostras amazônicas por $P C R$. Eletroforese em gel de agarose $(1,5 \%)$ de produtos de PCR amplificados a partir das amostras do rio Solimões, SOL-1 (1), SOL-3 (2), e do rio Negro, NEGM-2 (3), NEGM-3 (4) e NEGJ-1 (5). Amplificações realizadas com os oligonucleotídeos AVS-1 e AVS-2, para ficodnavírus. Controle negativo (-) com água e controle positivo (+) com DNA do vírus de Micromonas pusilla. Marcador de peso molecular de 100 pb (M). Gel corado com SYBR Green e visualizado sob luz UV.

Aventaram-se outras possibilidades para a não detecção por $P C R$ de ficodnavírus nas amostras do rio Negro: problemas no processamento de todas as amostras desse rio, acarretando a perda significativa de material genético e, consequentemente, inviabilizando sua amplificação; a ausência de hospedeiros (fitoplâncton) no rio, o que poderia justificar a ausência dos vírus; ou, ainda, a redução da contagem viral no Negro como resultado da grande quantidade de SHs, assim como observado por Anesio et al. (2004).

Entretanto, todas as possibilidades foram descartadas. Problemas durante o processamento das amostras foram descartados, pois a amplificação por $P C R$ de miofagos foi obtida com sucesso em todas as amostras do rio Negro (Figura 33). O pressuposto da ausência de hospedeiros foi reconhecido como pouco provável após a análise dos dados de contagem e identificação de fitoplâncton (Tabela 4), a qual mostrou a presença de vários grupos de algas nas amostras. Já a redução da contagem viral como resultado do excesso de SHs foi desconsiderada uma vez que ficodnavírus foram amplificados a partir da amostra do rio Cuieiras, cujas características físicas são bastante semelhantes às do rio Negro (baixo pH e alta concentração de SHs).

A última hipótese levantada para explicar a não detecção de ficodnavírus no rio Negro foi a de que as $P C R$ s pudessem apresentar um resultado negativo devido ao alto índice de degeneração dos oligonucleotídeos utilizados (AVS-1 e AVS-2) e ao fato de não amplificarem o material genético de todos os ficodnavírus (Chen e Suttle, 1995), impedindo a detecção por PCR desses vírus. Na tentativa de contornar essa possibilidade, foram feitas alterações nas condições da reação de $P C R$, com a diminuição da restringência da reação através da diminuição da temperatura de anelamento e da concentração de $\mathrm{MgCl}_{2}$. Entretanto, não houve sucesso. 
Como alternativa, cogitou-se a utilização dos oligonucleotídeos desenhados por Larsen et al. (2008a), que têm como alvo o gene que codifica para a proteína major capsid do grupo de vírus NCLDV. Esta possibilidade não foi colocada em prática, entretanto, pois consideramos que ela não levaria à contemplação do objetivo do trabalho, devido ao fato de esses oligonucleotídeos terem como alvo uma maior gama de famílias virais, e não somente a Phycodnaviridae, e existirem apenas as sequências geradas pelo grupo de Larsen disponíveis para consulta, impossibilitando uma reconstrução filogenética robusta através da comparação das sequências amazônicas com as obtidas em diferentes ambientes aquáticos de outras latitudes. Por esse motivo, optamos, após diversos testes e análises, por dar continuidade ao trabalho com ficodnavírus somente com as amostras dos rios Cuieiras e Solimões.

Depois da PCR das amostras CUI-1, SOL-1, SOL-2 e SOL-3 com os oligonucleotídeos AVS-1 e AVS-2, os produtos amplificados foram separados por eletroforese em gel de agarose e os fragmentos de $700 \mathrm{pb}$ removidos do gel (Figura 18). O DNA purificado da agarose foi então reamplificado para a obtenção de maior quantidade de $D N A$, necessária à análise do perfil da comunidade viral, através de DGGE.

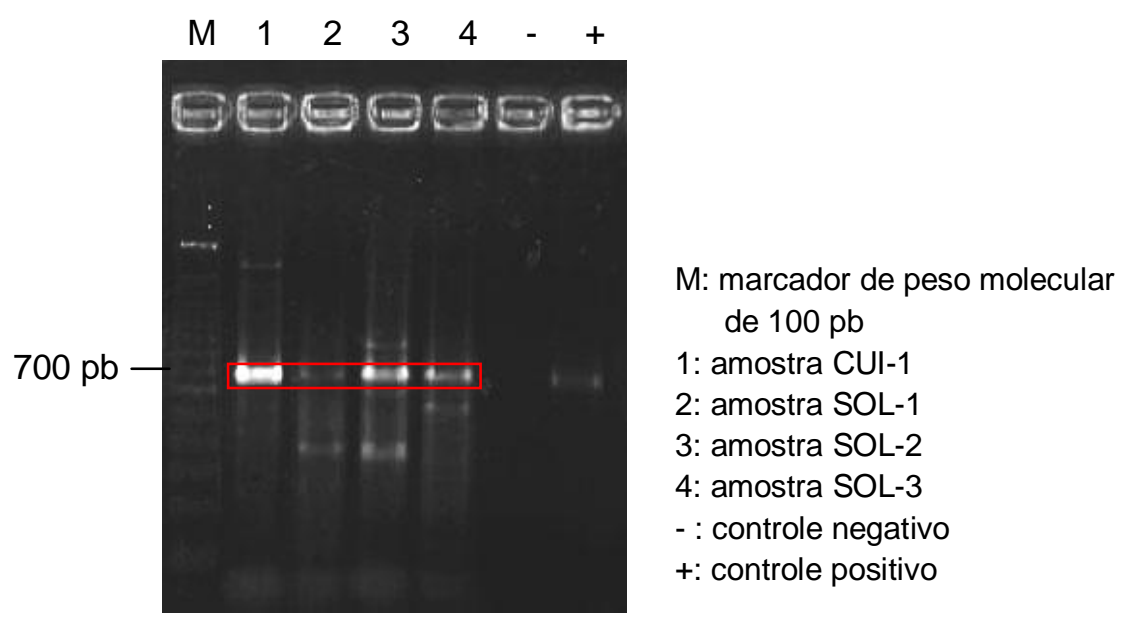

Figura 18. Detecção de ficodnavírus em amostras amazônicas por $P C R$. Eletroforese em gel de agarose $(1,5 \%)$ de produtos de $P C R$ amplificados a partir das amostras dos rios Cuieiras, CUl-1 (1), e Solimões, SOL1 (2), SOL-2 (3) e SOL-3 (4). Amplificações realizadas com os oligonucleotídeos AVS-1 e AVS-2, para ficodnavírus. Controle negativo (-) com água e controle positivo (+) com DNA do vírus de Micromonas pusilla. Marcador de peso molecular de $100 \mathrm{pb}(\mathrm{M})$. Gel corado com SYBR Green e visualizado sob luz UV.Marcação em vermelho indica os fragmentos que foram removidos do gel para serem reamplificados.

A padronização entre as amostras nos géis de DGGE foi realizada com base na quantidade de produto amplificado. Dessa maneira, apesar de a massa de DNA original em cada amostra ser desconhecida, foi possível verificar qual seria a variação relativa na riqueza das comunidades virais estudadas, assumindo a mesma eficiência de concentração no processamento de todas as amostras. 
O gel com os amplicons de ficodnavírus apresentou reduzido número de fragmentos, indicativo de baixa riqueza, e pequena variação temporal entre as amostras do rio Solimões (Figura 19A). O padrão eletroforético da amostra SOL-1 mostrou um fragmento ausente nas amostras SOL-2 e SOL-3 e a ausência de dois fragmentos, presentes no perfil eletroforético das outras duas amostras do mesmo rio (Figura 19B).

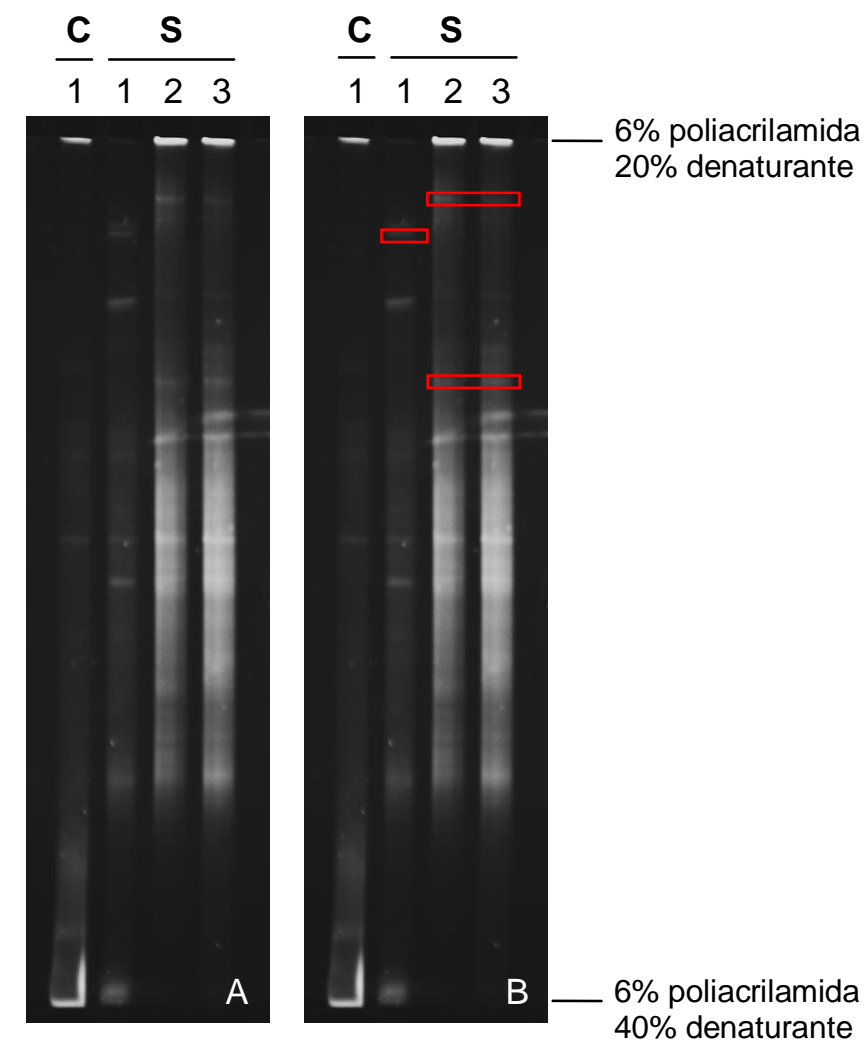

Figura 19. Análise do perfil da comunidade de ficodnavírus por DGGE. Eletroforese em gel de poliacrilamida (6\%), com gradiente denaturante de $20 \%$ a $40 \%$. Alíquotas de $25 \mu \mathrm{L}$ de produto de $P C R$ reamplificado das amostras dos rios Cuieiras (C) e Solimões (S), corridas a $60^{\circ} \mathrm{C}$ e $60 \mathrm{~V}$ por 20 horas. Gel corado com SYBR Green e visualizado sob luz UV. Em B, indicação em vermelho dos fragmentos ausentes em alguma das amostras do rio Solimões.

Entretanto, quando as sequências nucleotídicas dos fragmentos provenientes desse gel foram confrontadas com as sequências do GenBank, através de ambos - blastp e tblastx -, constatouse que o material genético amplificado era, em sua maioria, de origem bacteriana, sendo a espécie Flavobacterium johnsoniae e o gênero Polynucleobacter os mais frequentes (ANEXOS G e H). Das 64 sequências obtidas, apenas oito (12,5\%) eram de origem viral. Apesar de ser esperada a presença de bactérias menores que $0,45 \mu \mathrm{m}$ nos concentrados virais, uma vez que o último filtro utilizado na clarificação possuía poros de 0,45 $\mu \mathrm{m}$ de diâmetro, a amplificação de sequências bacterianas com os oligonucleotídeos AVS-1 e AVS-2 foi uma surpresa. Não há descrição de tal fato na literatura. 
A constatação da amplificação inespecífica e majoritária de genomas bacterianos com os oligonucleotídeos pretendidos para o estudo evidenciou a necessidade de modificações no procedimento de obtenção dos amplicons, para a seleção somente de DNA viral alvo. Para tanto, o trabalho com ficodnavírus foi reiniciado do zero, na busca por alternativas. Nesse sentido, realizou-se inicialmente um estudo sobre as sequências dos oligonucleotídeos AVS-1 e AVS-2. Por se tratar de oligonucleotídeos com muitas degenerações, levantou-se a hipótese de que talvez houvesse diferenças entre as sequências que amplificaram DNA viral e DNA bacteriano. Assim, tornar-se-ia possível um redesenho dos oligonucleotídeos, com um número menor de degenerações e maior especificidade. Após a análise das 64 sequências obtidas, constatou-se que não havia diferença na sequência dos oligonucleotídeos que amplificaram DNA viral e bacteriano. Apesar de ser possível diminuir o número de degenerações, um novo desenho dos oligonucleotídeos não selecionaria o $D N A$ viral.

Em seguida, tentou-se remover as células bacterianas da amostra, fisicamente, por filtração, anteriormente à extração de DNA. Entretanto, após esse tratamento, não foi possível uma amplificação eficaz por PCR (Figura 20A), nem mesmo com a reamplificação do material (Figura 20B).
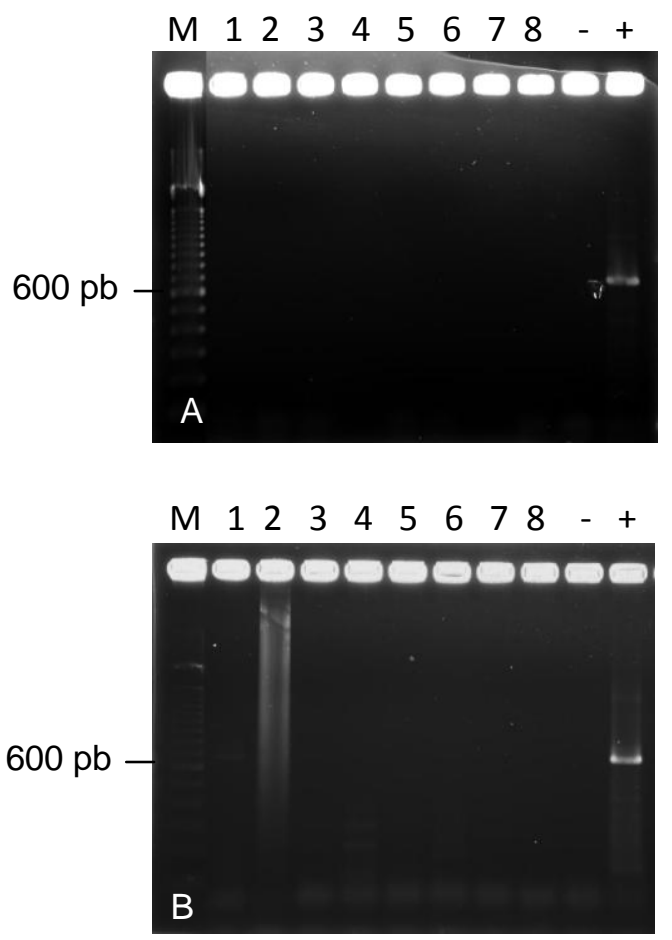

M: marcador de peso molecular de $100 \mathrm{pb}$

1: amostra CUI-1

2: amostra NEGM-1

3: amostra NEGM-2

4: amostra NEGM-3

5: amostras NEGJ-1

6: amostra SOL-1

7: amostra SOL-2

8: amostra SOL-3

- : controle negativo

+ : controle positivo

Figura 20. Amplificação e reamplificação de ficodnavírus a partir das amostras filtradas a 0,22 $\mu$ m. Eletroforese em gel de agarose $(1,5 \%)$ de produtos de $P C R$ amplificados a partir das amostras dos rios Cuieiras (1), Negro (2 a 5) e Solimões (6 a 8). PCRs realizadas com os oligonucleotídeos AVS-1 e AVS-2, para ficodnavírus. Controle negativo (-) com água e controle positivo (+) com DNA do vírus de Micromonas pusilla. Marcador de peso molecular de $100 \mathrm{pb}(\mathrm{M})$. Gel corado com SYBR Green e visualizado sob luz UV. Em A, produtos amplificados, e em B, produtos reamplificados. 
Como alternativa à separação física das células bacterianas das partículas virais, levantou-se a possibilidade da separação do DNA viral do bacteriano através de gradiente de césio. Porém, o volume de concentrado viral disponível no laboratório do Canadá, onde o trabalho estava sendo realizado no momento, não seria suficiente para a obtenção da massa de DNA necessária para tal procedimento.

O próximo teste realizado na tentativa de amplificar somente o DNA viral foi a substituição, na reamplificação, do oligonucleotídeo AVS-2 pelo oligonucleotídeo interno POL, também desenhado por Chen e Suttle (1995). Produtos da nested PCR foram separados por eletroforese (Figura 21), e os fragmentos do tamanho esperado (aproximadamente $500 \mathrm{pb}$ ) foram clonados. Com 0 sequenciamento do DNA de 10 clones escolhidos ao acaso, pudemos constatar que, apesar de a amplificação do DNA clonado resultar em fragmentos de tamanhos variando entre $300 \mathrm{pb} \mathrm{e}$ aproximadamente $750 \mathrm{pb}$, tanto de origem viral, quanto bacteriana, todos, e somente os fragmentos de $600 \mathrm{pb}$ eram de origem viral (Figura 22). Desse modo, obtivemos sucesso em selecionar o DNA viral desejado.

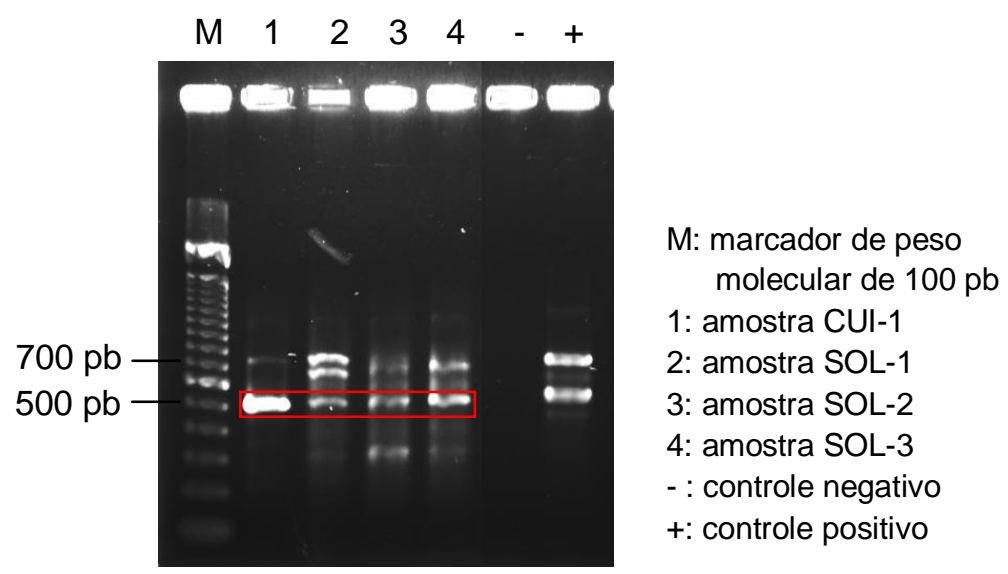

Figura 21. Nested $P C R$ de ficodnavírus. Eletroforese em gel de agarose $(1,5 \%)$ de produtos de Nested $P C R$, reamplificados a partir das amostras dos rios Cuieiras, CUl-1 (1), e Solimões, SOL-1 (2), SOL-2 (3) e SOL-3 (4). Amplificações realizadas com os oligonucleotídeos AVS-1 e POL, para ficodnavírus. Controle negativo (-) com água e controle positivo (+) com DNA do vírus de Micromonas pusilla. Marcador de peso molecular de $100 \mathrm{pb}(\mathrm{M})$. Gel corado com SYBR Green e visualizado sob luz UV. Em vermelho, fragmentos do tamanho esperado. 


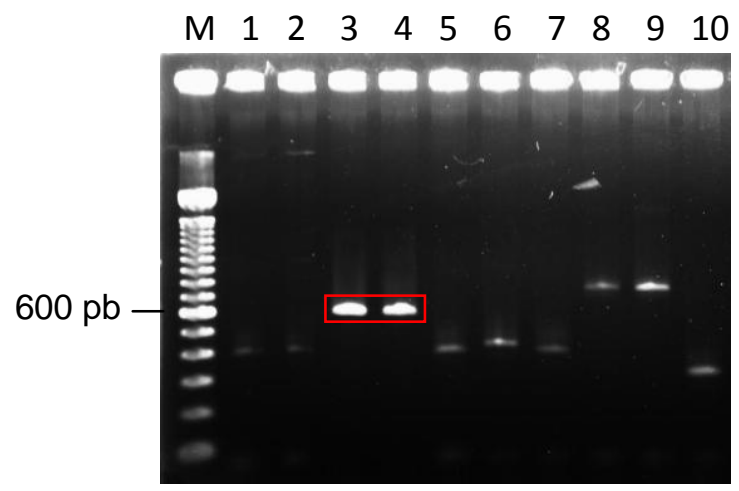

Figura 22. $P C R$ a partir de colônias bacterianas contendo $D N A$ clonado. Eletroforese em gel de agarose $(1,5 \%)$ de produtos de nested-PCR, reamplificados a partir de colônias bacterianas contendo DNA clonado (1 a 10). Amplificações realizadas com os oligonucleotídeos T3 e T7 do kit de clonagem (Invitrogen). Marcador de peso molecular de 100 pb (M). Gel corado com SYBR Green e visualizado sob luz UV. Em vermelho, detalhe para as colônias 3 e 4 que originaram amplicons de 600 pb, os únicos de origem viral.

Tais amplicons foram analisados por DGGE, novamente em busca do perfil da comunidade de ficodnavírus das amostras. Entretanto, a eletroforese resultou em um perfil com praticamente apenas um fragmento, na mesma posição do gel em todas as amostras (Figura 23). Esse fato é bastante atípico para comunidades virais ambientais, como mostrado por Short e Suttle (2003), que analisaram a variação temporal de comunidades marinhas de vírus algais por um período de 64 semanas e obtiveram perfis bastante variados e com múltiplos fragmentos.

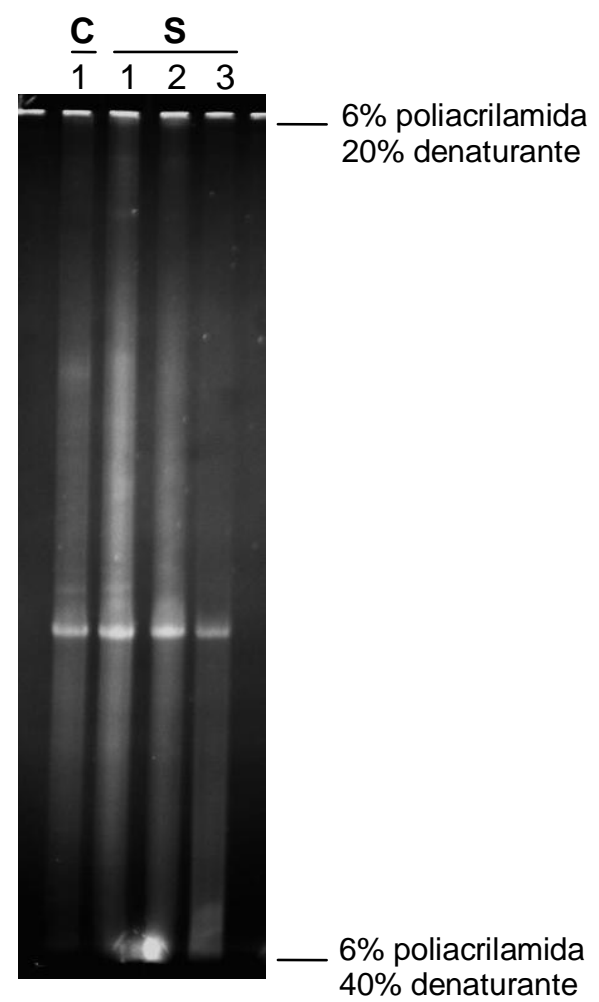

Figura 23. Análise do perfil da comunidade de ficodnavírus por DGGE. Eletroforese em gel de poliacrilamida (6\%), com gradiente denaturante de $20 \%$ a $40 \%$. Alíquotas de $25 \mu \mathrm{L}$ de produto de Nested PCR reamplificado das amostras dos rios Cuieiras (C) e Solimões (S), corridas a $60^{\circ} \mathrm{C}$ e $60 \mathrm{~V}$ por 20 horas. Gel corado com SYBR Green e visualizado sob luz UV. 
Na tentativa de se obter uma melhor separação dos fragmentos de $D N A$, outros géis foram preparados, com diferentes gradientes denaturantes (15\% a $65 \%$ e $25 \%$ a $35 \%$ ) e diferentes concentrações de poliacrilamida (6\% e $7 \%)$. Porém, os géis continuaram a apresentar perfis com apenas um fragmento, inviabilizando a análise do perfil da comunidade de ficodnavírus nas amostras amazônicas, pela técnica de DGGE. Cabe, entretanto, ressaltar que, tal método tem ampla aplicação em estudos de ecologia aquática, tendo sido aplicado com eficiência em estudos prévios não somente sobre vírus algais (Short e Suttle, 1999; Short e Suttle, 2002; Short e Suttle, 2003; Schroeder et al., 2003; Martínez et al., 2007; Clasen e Suttle, 2009), mas também sobre fagos (Wilson et al., 2000; Larsen et al., 2001; Short e Suttle, 2005; Tijdens et al., 2008), e fitoplâncton (Larsen et al., 2001).

Os possíveis fragmentos oriundos do DGGE seriam utilizados na construção de biblioteca gênica, método recentemente aplicado por Clasen e Suttle (2009) em estudo sobre a diversidade dos ficodnavírus de água doce e predição de hospedeiros. A opção por esta estratégia, em detrimento à construção de biblioteca a partir de produtos de $P C R$, tinha como objetivo maximizar a eficiência na obtenção de sequências diferentes, evitando o sequenciamento de amostras redundantes (Ferris et al., 1996). Isso porque bibliotecas gênicas construídas a partir de produtos de $P C R$ podem fornecer dados comprometidos, já que há clonagem preferencial de alguns fragmentos em detrimento de outros.

Entretanto, devido aos resultados descritos e discutidos anteriormente sobre a inaplicabilidade do DGGE para amostras de ficodnavírus, optou-se pela construção da biblioteca gênica a partir dos produtos de $P C R$. As clonagens foram verificadas através do sequenciamento de um número reduzido de clones antes da sua realização em larga escala. Desta vez, das 24 sequências obtidas, 22 (91,7\%) eram de origem viral, pertencentes à família Phycodnaviridae.

A partir da biblioteca gênica, um total de 104 sequências de ficodnavírus foi obtido, sendo 65 das amostras do rio Solimões (SOL-1, SOL-2 e SOL-3) e 39 da amostra do rio Cuieiras (CUI-1).

\subsubsection{Reconstrução filogenética}

Após o alinhamento múltiplo, uma primeira reconstrução filogenética foi realizada a partir de um conjunto de dados de 654 táxons, que incluíam as 104 sequências de clones amazônicos, 441 sequências de clones de várias partes do mundo e 109 de ficodnavírus isolados, pertencentes a todos os gêneros da família Phycodnaviridae.

Primeiramente, a árvore (Figura 24) mostrou que as sequências da DNA polimerase dos clones ambientais agrupam-se em vários clados dentro da família Phycodnaviridae, e que estes são distintos dos clados que abrangem sequências de ficodnavírus isolados. A árvore mostrou também que os ficodnavírus de água doce (clones amazônicos e de outras partes do mundo) são mais proximamente relacionados com isolados marinhos $M p V$, $O s V$ e $B p V$ do que com o vírus $P B C V$, 
também de água doce. Esse dado foi observado anteriormente em três estudos sobre taxonomia de ficodnavírus: o de Larsen et al. (2008a), o de Short e Short (2008), e o de Clasen e Suttle (2009).

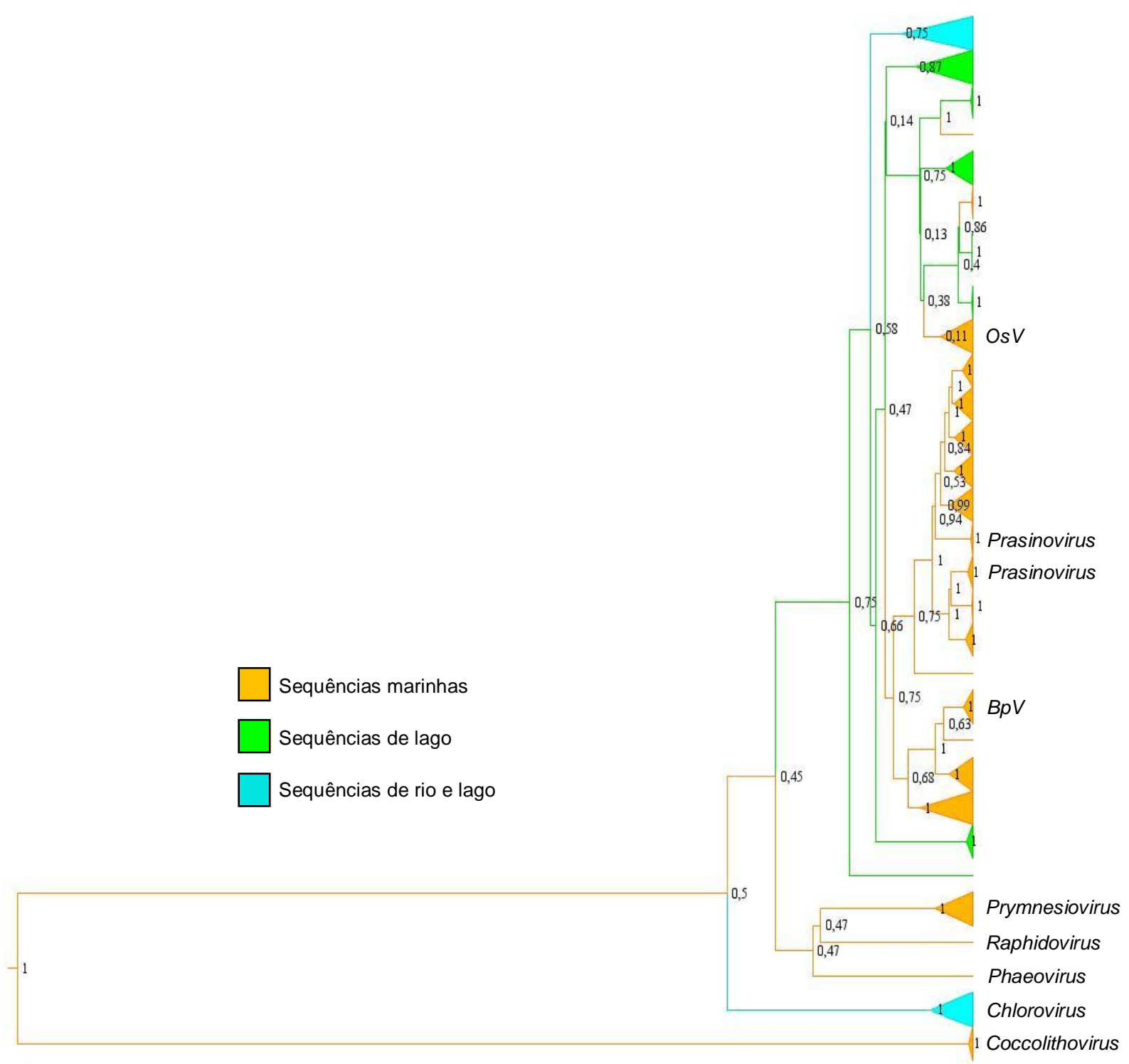

Figura 24. Relação filogenética dos ficodnavírus baseada em sequências de aminoácidos inferidas a partir das sequências nucleotídicas do gene da DNA polimerase $\mathrm{B}$, pelo método máxima verossimilhança. Ramos contendo sequências marinhas identificados em laranja; ramos contendo sequências de lagos identificados em verde; ramos contendo sequências de água doce (rios e lagos) identificados em azul.

Uma possível explicação para a distância evolutiva encontrada entre os ficodnavírus de água doce estudados e os $P B C V$ s residiria no fato de o $P B C V$ ser um vírus que infecta uma alga simbionte, diferentemente dos demais vírus que infectam algas de vida livre. Posto que o Paramecium bursaria, hospedeiro da alga Chlorella, suporta salinidades de $2 \%$ a 3 \%o (Smurov e Fokin, 2001), seu interior 
mimetizaria, para a alga hospedeira do vírus, um ambiente com condições diferentes daquelas da água doce.

Em seguida, foram realizadas análises filogenéticas mais detalhadas, das quais excluíram-se as sequências mais divergentes, que incluíam ficodnavírus dos gêneros Prymnesiovirus, Raphidovirus, Phaeovirus, Chlorovirus e Coccolithovirus. A nova árvore mostrou a existência de grupos monofiléticos de ficodnavírus muito divergentes, próximo às extremidades dos ramos, demonstrando intensa cladogênese recente (Figura 25). Tal dado foi assumido como indicativo de expansões demográficas de populações virais intimamente relacionadas, as quais foram identificadas como Demes (setores amarelos da árvore da Figura 25), para fim dos estudos demográficos subsequentes (Tabela 6).

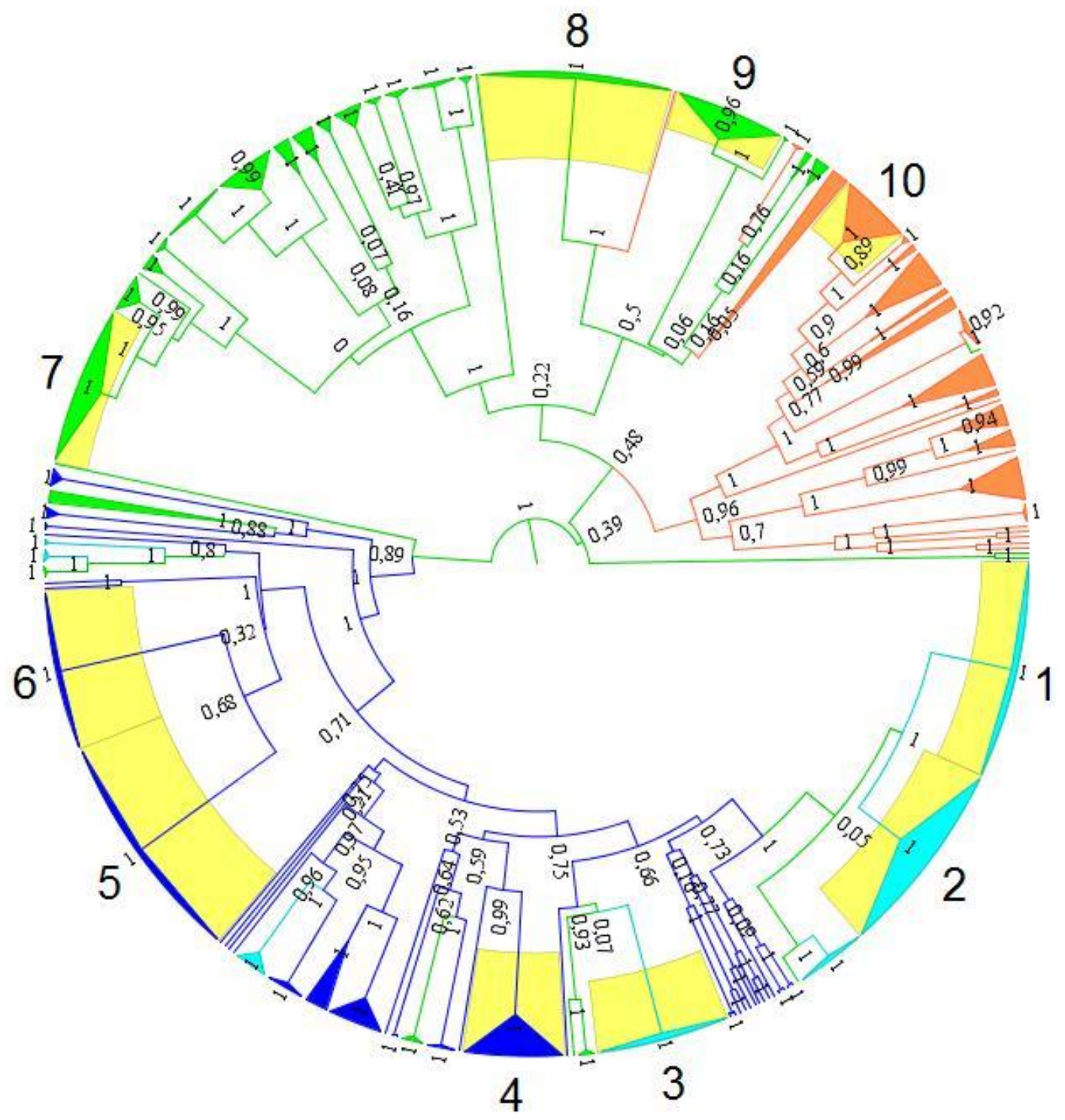

Figura 25. Relação filogenética dos ficodnavírus baseada em sequências de aminoácidos inferidas a partir das sequências nucleotídicas do gene da DNA polimerase $\mathrm{B}$, pelo método máxima verossimilhança. Ramos contendo sequências marinhas, de rios, de lagos e de água doce (rios e lagos) marcados em laranja, azul-escuro, verde e azul-claro, respectivamente. Demes identificadas de 1 a 10 e representadas pelos setores amarelos. 
Tabela 6 - Identificação das Demes.

\begin{tabular}{cc}
\hline \hline Deme & Origem das sequências \\
\hline 1,2 e 5 & Reservatório Chatfield (US) e Rio South Platte (US) \\
3 & Reservatório Chatfield (US), Rio South Platte (US) e Lago Ontário (CA) \\
4 & Rio Solimões (BR) \\
6 & Rio Cuieiras River (BR) \\
7 e 9 & Lago Ontário (CA) \\
8 & Lago Ontário (CA) e Lago Crawford (CA) \\
10 & Mar Mediterrâneo \\
\hline $\begin{array}{l}\text { US: Estados Unidos da América } \\
\text { CA: Canadá } \\
\text { BR: Brasil }\end{array}$
\end{tabular}

Além disso, os dados obtidos mostraram que as amostras de água doce agrupam-se separadamente das amostras marinhas, em acordo com resultados apresentados por Clasen e Suttle (2009); a topologia da árvore obtida também sugeriu uma relação distante entre as Demes de ficodnavírus de ambientes lóticos e as de ambientes marinhos (Figura 25). Diferentemente, dados apresentados por Short e Short (2008) e por Bellec et al. (2009) mostraram apenas uma tendência ao agrupamento dos vírus em função do ambiente, uma vez que não obtiveram sustentação estatística suficiente para certificar uma afirmação.

\subsubsection{Migração entre ambientes aquáticos distintos}

Com o propósito de avaliar a aparente restrição do fluxo gênico dos ficodnavírus, sugerida nas análises filogenéticas (Figura 25), e visto que possuíamos informação sobre o local de coleta das amostras estudadas, realizou-se uma análise para estudar o movimento dos ficodnavírus e para estimar a quantidade de troca de linhagens entre os ambientes aquáticos.

Os resultados mostraram uma significativa troca genética entre os ambientes aquáticos de água doce (lótico e lêntico), e taxas de trocas entre os ambientes marinho e de água doce 1000 vezes menor, sendo que o valor mínimo encontrado foi para o fluxo genético de mar para rio (100 mil vezes menor) (Figura 26). 


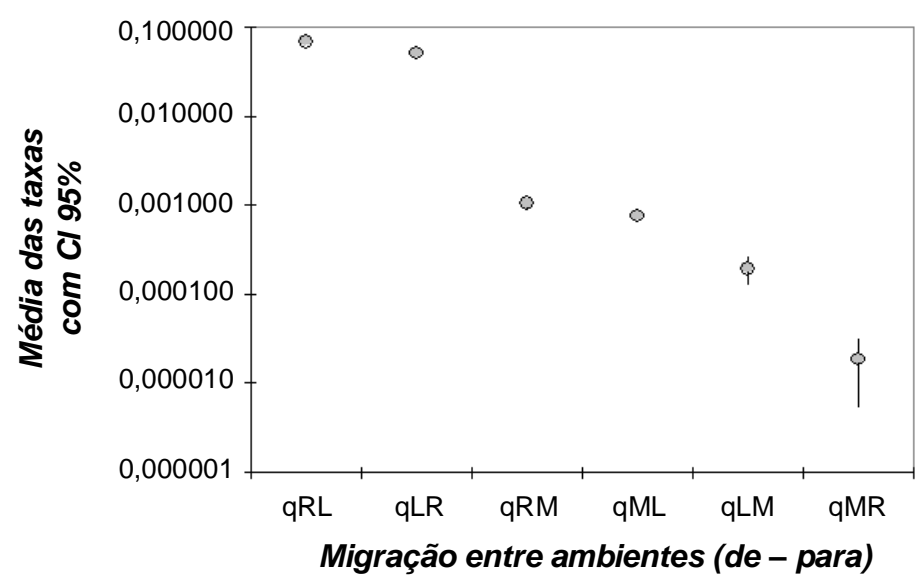

Figura 26. Taxa de migração dos ficodnavírus entre os ambientes aquáticos. qRL indica a taxa de movimentação de vírus de rio para lago; qLR indica a taxa de movimentação de vírus de lago para rio; qRM indica a taxa de movimentação de vírus de rio para mar; $\mathrm{qML}$ indica a taxa de movimentação de vírus de mar para lago; qLM indica a taxa de movimentação de vírus de lago para mar; e qMR indica a taxa de movimentação de vírus de mar para rio.

A diferença significativa encontrada entre as taxas de fluxo gênico foi indicada pela ausência de sobreposição entre as estimativas resultantes de $95 \%$ do intervalo de mais alta probabilidade (95\% HPD). Tal dado rejeita a hipótese de panmixia dos ficodnavírus, segundo a qual estes vírus estariam randomicamente espalhados entre os diferentes ambientes aquáticos, e dá suporte à ideia de que, provavelmente, existam fatores que restringem o fluxo gênico dos ficodnavírus entre ambientes aquáticos.

Uma vez que os valores de troca genética entre rios e lagos foram os maiores, apesar de na mesma ordem de magnitude, tentou-se então avaliar como seria a variação da taxa de troca em função da árvore utilizada como base para a estimativa. Para tanto, estimativas das taxas resultantes das análises BayesTraits, a partir de uma amostra de árvores obtidas durante as corridas de MCMC, foram plotadas e indicaram que, independentemente das taxas coestimadas para cada árvore, a proporção - sumarizada pela linha com alto coeficiente de correlação $(r 2=0,99)$ - foi robusta para valores de qRL maiores que qLR (Figura 27). 


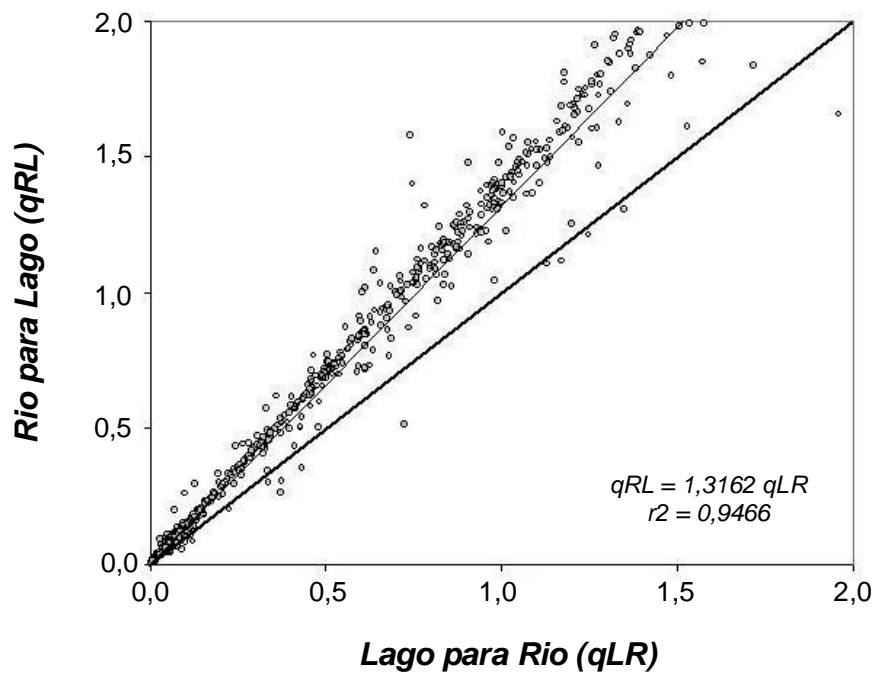

Figura 27. Taxa de migração de ficodnavírus entre ambientes de água doce. qRL indica a taxa de movimentação de vírus de rio para lago; qLR indica a taxa de movimentação de vírus de lago para rio.

Em suma, concluímos que os resultados obtidos sustentam a tese de que os ficodnavírus não são panmíticos em relação ao ambiente que ocupam. Consequentemente, nossos dados sugerem que a restrição no fluxo genético entre ambientes pode ter importante papel na evolução e dispersão dos ficodnavírus, e apontam para a existência de restrições severas ao movimento desses vírus entre ambientes de água doce e salgada. Tais restrições poderiam possivelmente explicar a colonização ou não de sistemas específicos como o rio Negro.

Um fator levantado como possível agente de restrição do fluxo genético dos ficodnavírus foi a salinidade. Em estudo realizado por Cissoko et al. (2008), os autores relataram uma drástica redução na contagem viral de amostras de água doce após a adição de água salgada. Entretanto, o mesmo efeito não foi observado com a adição de água doce às amostras marinhas, indicando que os vírus marinhos podem tolerar melhor as mudanças de salinidade, fato também observado para bactérias. Tais dados corroboram não somente a ideia de que a salinidade é um fator de restrição ao movimento de vírus do ambiente aquático de água doce para o marinho, mas também nossos resultados, que indicaram movimento de ficodnavírus do mar para ambientes de água doce, mas não o contrário.

Similarmente, sabe-se que o fitoplâncton marinho tolera bem mudanças de salinidade, provavelmente devido à necessidade imposta ao grupo pelas marés, precipitações e outros fenômenos ambientais (Kirst, 1989), enquanto que o fitoplâncton de água doce normalmente é totalmente substituído por espécies marinhas, em regiões estuarinas, onde a salinidade varia de 0,5 $\%$ a $10 \%$ (Lionard et al., 2005). Portanto, os dados da literatura sugerem que vírio, bactério e fitoplâncton de água doce são mais suscetíveis a estresses osmóticos que os marinhos. 
No sentido de melhor entender as migrações dos ficodnavírus, tentamos inferir a posição da raiz nas árvores MCMC. Apesar de a maior probabilidade obtida ter sido para o posicionamento da raiz no ambiente marinho, a sobreposição de altos valores de 95\% HPD para todos os ambientes não nos permitiu fazer uma inferência confiável sobre a posição da raiz da árvore (Figura 28).

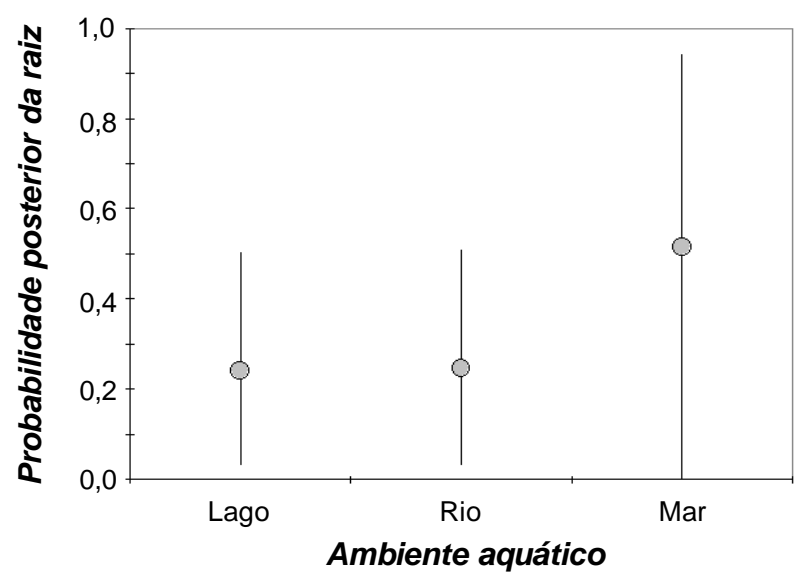

Figura 28. Probabilidade posterior do posicionamento da raiz nos três ambientes aquáticos: lago, rio e mar.

O fato de o $P B C V$ ter irradiado de ramos profundos da árvore, adjacente a amostras marinhas divergentes, também contribuiu para a impossibilidade de posicionamento da raiz da árvore, apesar da inclusão de sequências de ficodnavírus isolados tê-la posicionado no mar, na árvore de maior credibilidade de clado.

Entretanto, os dados de fluxo genético viral do mar para ambientes de água doce, juntamente com os dados discutidos anteriormente sobre a maior tolerância de micro-organismos marinhos a estresses osmóticos, e a sugestão do posicionamento da raiz da árvore filogenética no mar resultante da maior probabilidade posterior (Figura 28), apesar de não obstantes para uma afirmação assertiva sobre a origem marinha dos ficodnavírus, vão ao encontro da história evolutiva do planeta. Isso porque, a vida, a princípio originada e restrita aos oceanos, e registrada nos fósseis dos estromatólitos de 3,5 bilhões de anos, só pôde conquistar o ambiente terrestre (água doce) após a formação da camada que ozônio no final do período Cambriano (495 milhões de anos) (Gradstein et al., 2005), a qual tornou possível a vida em terra, através da contenção da radiação ultravioleta.

\subsubsection{Dinâmica populacional}

Com o objetivo de entender melhor a flutuação temporal de algumas populações de ficodnavírus, as sequências das dez Demes foram analisadas, sendo que as estimativas do tamanho da população foram obtidas através da multiplicação do dado da população efetiva pelo tempo de geração (Ne.g). 
Como resultado dessa análise, observou-se uma redução significativa no tamanho das populações de ficodnavírus, entre 500 e 300 mil anos atrás. Tal redução também foi apontada pelos dados de 95\% HPD, e sugere uma complexa dinâmica de flutuação das populações de ficodnavírus, em uma longa escala de tempo (Figura 29).

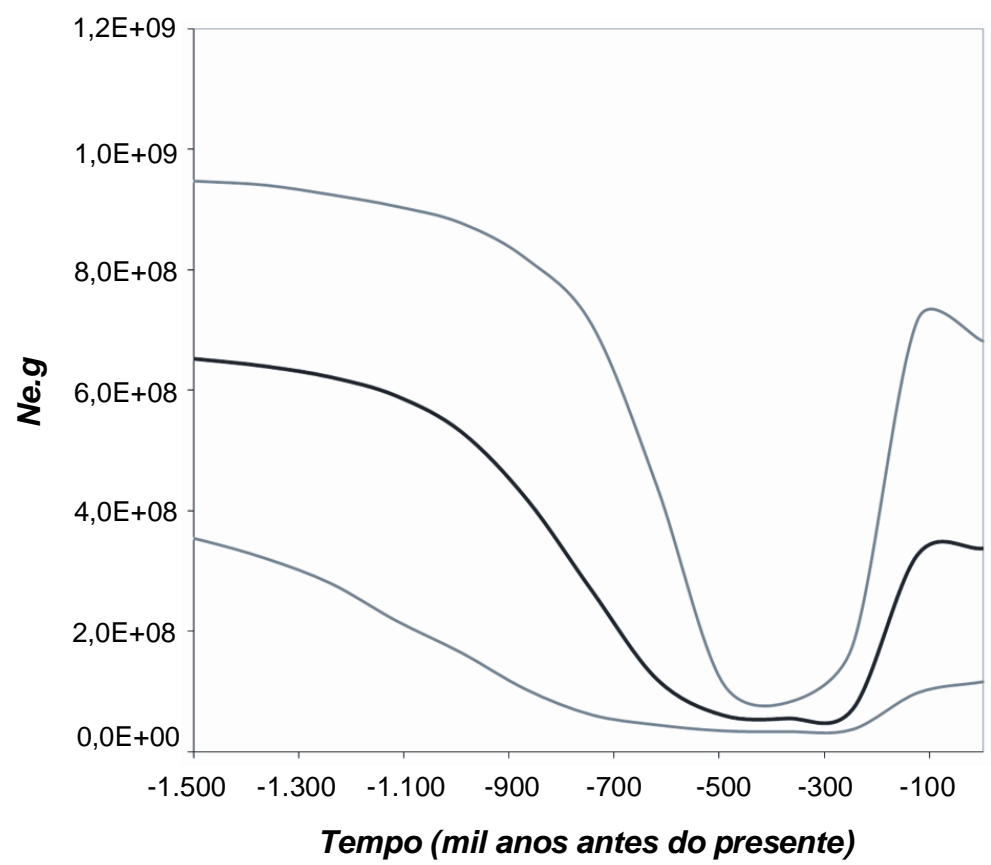

Figura 29. Dinâmica populacional dos ficodnavírus no último 1,5 milhão de anos, durante o Quaternário. 95\% HPD mostradas nas linhas cinza-claro e a média mostrada na linha cinza-escuro. Ne.g indica o tamanho das populações.

Considerando as dinâmicas das diferentes Demes em mais detalhe (Figura 30), após o gargalo de 300 mil anos atrás, há um sinal recuperado para a maioria das populações, demonstrando um aumento considerável no número de linhagens após a queda, cerca de 300 mil anos atrás. A estacionaridade ou uma redução no número de linhagens parece acontecer mais próximo ao presente, há 100 mil anos, corroborando a assinatura apresentada na Figura 29.

Ainda segundo essa análise, observou-se que a maior população viral (indicada pelo valor Ne.g) foi a da Deme 10, composta por ficodnavírus marinhos que infectam Ostreococcus, e nenhuma diferença específica ou particular às Demes amazônicas em comparação com as Demes de outras localidades foi detectada. Entretanto, é interessante notar que a Deme 2 (Reservatório Chatfield - US e Rio South Platte - US) e a Deme 4 (Rio Solimões) não apresentaram uma redução severa no tamanho das populações virais nos últimos 300 mil anos, em contraposição às demais. Cabe ainda ressaltar a aparente constância do tamanho populacional da Deme do rio Solimões e o aumento populacional constante da Deme 2, no período analisado. 


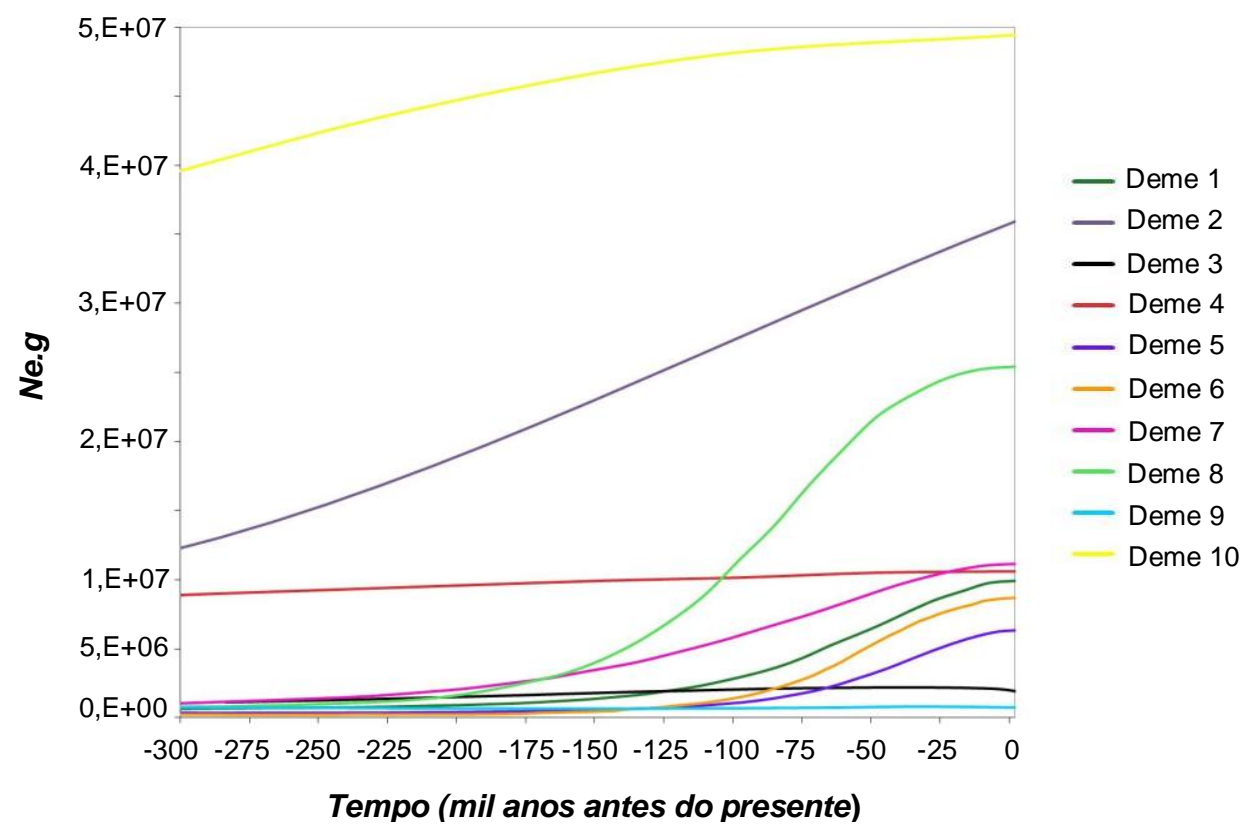

Figura 30. Dinâmica populacional das Demes de ficodnavírus nos últimos 300 mil anos. Ne.g indica o tamanho das populações.

Assim, a análise da dinâmica populacional dos ficodnavírus apresentou como resultado-chave o dado de que essas populações virais tiveram uma variação temporal significativa (Figura 29), na qual a maioria das Demes cresceu, desde o gargalo ocorrido há 400 mil anos (Figuras 29 e 30).

A primeira hipótese para explicar esse dado seria a de uma distorção como resultado de problemas amostrais. Entretanto, a maior parte das reduções dos tamanhos populacionais que ocorreram há 400 mil anos é justificada pela topologia da árvore mostrada na Figura 25, a qual indicou uma redução nos eventos cladogênicos antes da explosão das linhagens na maioria das Demes. Não obstante, distorções amostrais, nesse caso, não reduziriam a queda populacional observada, uma vez que uma superamostragem diminuiria ainda mais a probabilidade de encontrarmos uma raiz mais antiga diferente para cada Deme, o que acarretaria valores de Ne.g ainda menores durante o gargalo (Felsenstein, 2004).

Partindo do princípio de que a redução na população das Demes não foi resultado de problemas amostrais, ela poderia ser explicada pelo processo de nascimento e morte, boom and bust, o qual faria com que as linhagens mais antigas morressem nas Demes (Zanotto et al., 1996). Tal princípio poderia explicar a flutuação na dinâmica populacional das Demes e o platô observado em algumas delas, próximo ao presente (Figura 30).

Cabe salientar ainda que uma dinâmica boom and bust (Ferguson et al., 1999) concorda com o modelo de controle populacional Kill the winner, proposto por Thingstad (2000), além de ser esperada nesse caso, visto que vírus algais são importante agentes no controle da dinâmica de 
sucessão de populações algais hospedeiras, sendo notadamente responsáveis por terminações de florações fitoplanctônicas (Castberg et al., 2001; Brussaard, 2004a).

Os dados obtidos são corroborados pelo registro paleontológico disponível, uma vez que, de acordo com a nossa reconstrução temporal dos eventos, baseada na taxa de mudança de $1,4^{-8} \mathrm{~s} / \mathrm{s} / \mathrm{y}$, a redução demográfica no número de linhagens (Figura 29) parece ter ocorrido entre 1,5 milhão e 300 mil anos atrás, no final do Permiano, período conhecido por ter sido o momento da mais profunda extinção em massa marinha já ocorrida na história do planeta, com a eliminação de $90 \%$ das espécies (Erwin, 1993). Ainda, dados geocronológicos do sul da China revelam que o principal pulso de extinção ocorreu há menos de 500 mil anos (Bowring et al., 1998), período que coincide com a erupção de basalto siberiano (Campbell et al., 1992; Renne et al., 1995) e com uma abrupta mudança na quantidade de $\delta^{13} \mathrm{C}$ (Baud et al., 1989). Essa época foi marcada por flutuações climáticas que culminaram na formação de geleiras sobre os continentes, e por mudanças radicais na biota, com a extinção dos nanofósseis calcáreos Discoaster surculus e Discoaster pentaradiatus, e do foraminífero planctônico Globigerinoides extremus, por exemplo (Gradstein et al., 2005; Rio et al., 1998). Interessantemente, após um crescimento considerável no tamanho das populações virais, coincidente com o período interglacial Eemiano, mais quente, observou-se um declínio das populações, levando ao presente (Figura 29).

\subsection{Myoviridae}

\subsubsection{Análise molecular}

O teste para verificação do método mais eficiente de extração de DNA para análise de miofagos foi realizado da mesma maneira descrita anteriormente para ficodnavírus (item 5.4.1). Os DNAs obtidos foram utilizados em reações de PCR com os oligonucleotídeos CPS-4 e CPS-9, originalmente escolhidos para o estudo de miofagos.

Uma vez que nenhuma das amostras foi amplificada (Figura 31), tentou-se a reamplificação dos produtos de $P C R$, para verificar se o não aparecimento de fragmentos no gel seria resultado da pouca quantidade de amplicons. Entretanto, não houve sucesso. 


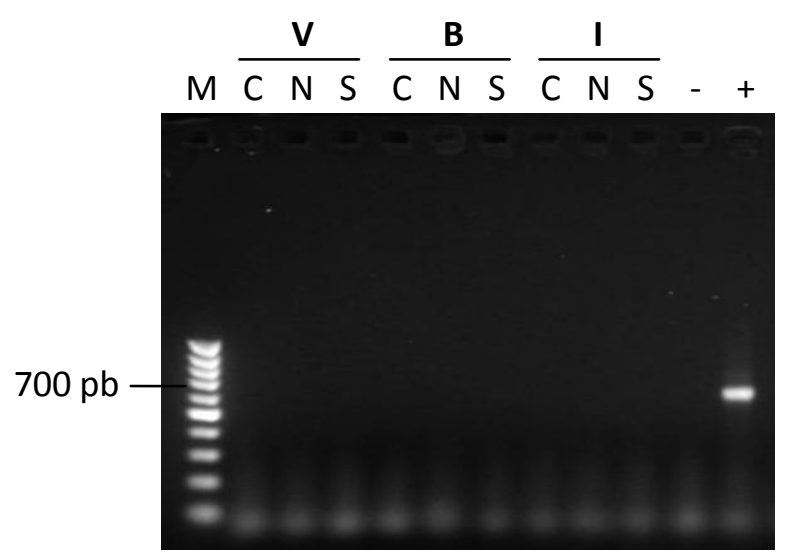

Figura 31. Teste de eficiência dos métodos de extração de DNA de miogafos. Eletroforese em gel de agarose $(1,5 \%)$ de produtos de $P C R$ amplificados a partir das amostras CUI-1 (C), NEGM-1 (N) e SOL-2 (S), dos rios Cuieiras, Negro e Solimões, respectivamente. DNA extraído com PowerSoil DNA kit $\left(\mathrm{MoBio}^{\circledR}\right)$, a partir do material tratado com Vertrel ${ }^{\circledR}(\mathrm{V})$, do concentrado viral bruto (B), e da interface resultante do tratamento com Vertrel ${ }^{\circledR}(\mathrm{I})$. Amplificações realizadas com os oligonucleotídeos CPS-4 e CPS-9, para miofagos. Controle negativo (-) com água e controle positivo (+) com DNA do vírus Spwm-1. Marcador de peso molecular de 100 pb (M). Gel corado com SYBR Green e visualizado sob luz UV.

Como nenhuma das amostras foi amplificada, não foi possível analisar os diferentes métodos de extração de DNA com esses resultados. Porém, uma vez que tal análise foi possível com os dados de ficodnavírus, optou-se por adotar o mesmo procedimento de extração de DNA tanto para as análises de ficodnavírus como para de miofagos, para que se mantivesse um padrão procedimental com todas as amostras.

Visto que o uso dos oligonucleotídeos CPS-4 e CPS-9 mostrou-se ineficiente para a amplificação de miofagos nas amostras amazônicas, a busca por novos conjuntos de oligonucleotídeos fez-se necessária. Foram então realizados testes com outros conjuntos já descritos na literatura (AN15 MCPF5 e AN15 MCPR5, CPS-1 e CPS-2, e CPS-1 e CPS-8), nos quais se observou a amplificação de genoma viral somente com CPS-1 e CPS-8. Entretanto, assim como no caso dos ficodnavírus, as amostras do rio Negro não foram amplificadas (Figura 32). 


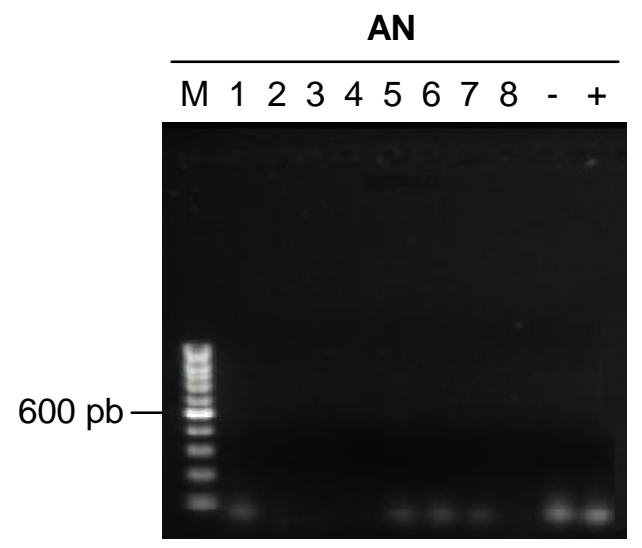

M: marcador de peso molecular de $100 \mathrm{pb}$

1: amostra CUI-1

2: amostra NEGM-1

3: amostra NEGM-2

4: amostra NEGM-3

5: amostra SOL-1

6: amostra SOL-2

7: amostra SOL-3

8: amostra NEGJ-1

- : controle negativo

+ : controle positivo
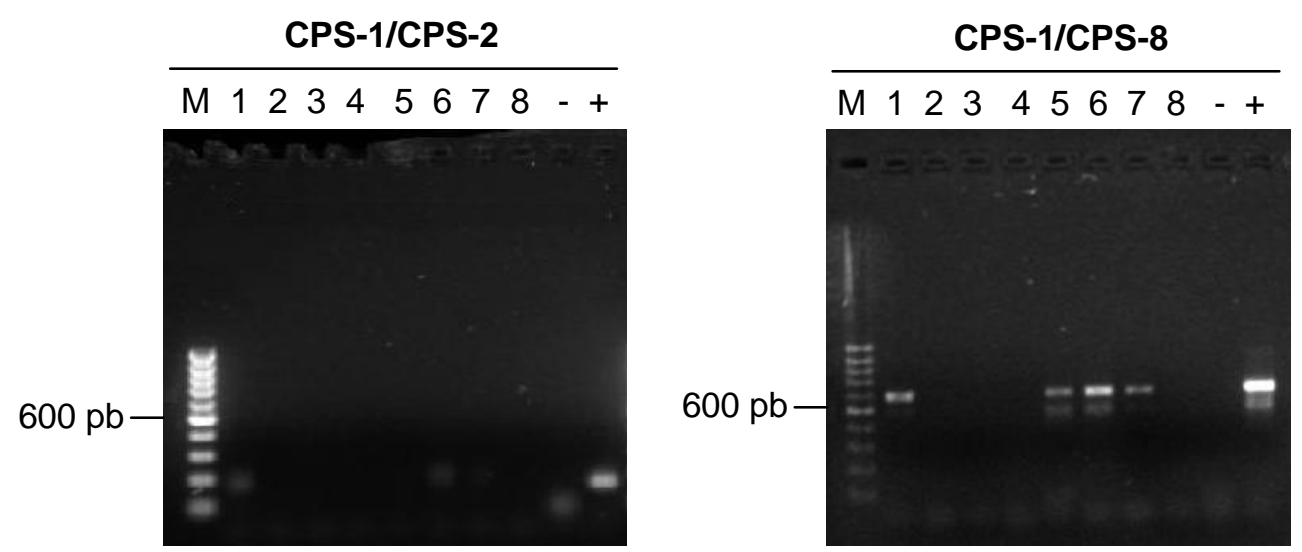

Figura 32. Detecção de miofagos nas amostras amazônicas por $P C R$. Eletroforese em gel de agarose $(1,5 \%)$ de produtos de PCR amplificados a partir das amostras dos rios Cuieiras (CUI), Negro (NEGM e NEGJ) e Solimões (SOL) com os oligonucleotídeos AN15, CPS-1 e CPS-2, e CPS-1 e CPS-8. Controles negativos com água e controles positivos com DNA purificado de fago T4. Marcador de peso molecular de 100 pb. Géis corados com SYBR Green e visualizados sob luz UV.

Na tentativa de se detectarem os miofagos em todas as amostras, os oligonucleotídeos MZIA1 bis e MZIA-6 foram testados e, desta vez, obteve-se sucesso. A amplificação de região do gene da glicoproteína de superfície gp23 de miofagos com os oligonucleotídeos MZIA foi possível em todas as amostras (Figura 33). 


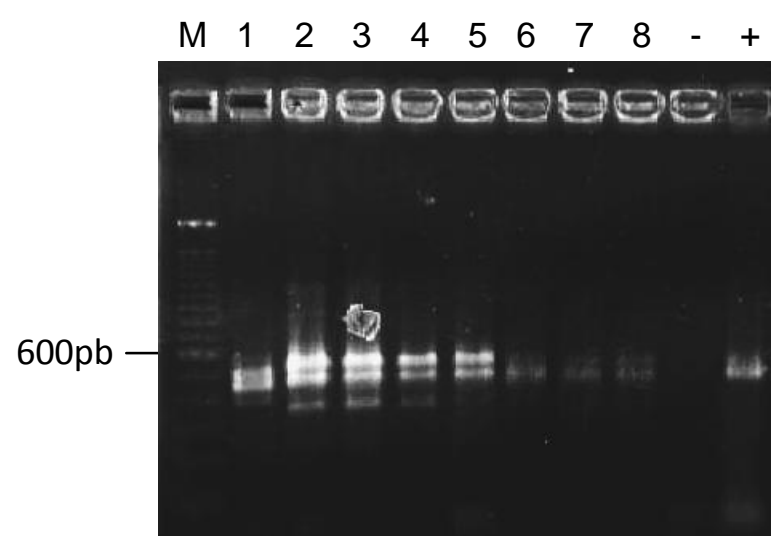
M: Marcador de peso
molecular (100pb)
1: amostra CUI-1
2: amostra NEGM-1
3: amostra NEGM-2
4: amostra NEGM-3
5: amostra NEGJ-1
6: amostra SOL-1
7: amostra SOL-2
8: amostra SOL-3
- : controle negativo
+: controle positivo

Figura 33. Detecção de miofagos nas amostras amazônicas por PCR. Eletroforese em gel de agarose (1,5\%) de produtos de PCR amplificados a partir das amostras dos rios Cuieiras (CUI), Negro (NEGM e NEGJ) e Solimões (SOL) com os oligonucleotídeos MZIA-1bis e MZIA-6. Controle negativo com água e controle positivo com DNA purificado de fago T4. Marcador de peso molecular de $100 \mathrm{pb}$. Gel corado com SYBR Green e visualizado sob luz UV.

Para a aplicação em $D G G E$, os fragmentos de 600 pb foram acrescidos de um grampo GC (guanina e citosina) para assegurar que a denaturação da dupla fita de DNA no gel de bis-acrilamida não ocorresse de maneira completa. Isso porque, uma vez denaturado, o produto de $P C R$ continua migrando no gel como fita simples de $D N A$, independentemente do gradiente denaturante e, portanto, descaracterizando a técnica e comprometendo a análise (Roelfsema e Peters, 2005).

O gel de $D G G E$, para a análise do perfil da comunidade de miofagos nas amostras amazônicas, mostrou boa separação do material genético em múltiplos fragmentos bem definidos (Figura 34A). A confirmação de que o material observado era mesmo de miofagos foi obtida através do sequenciamento dos fragmentos indicados em vermelho na Figura 34B. 

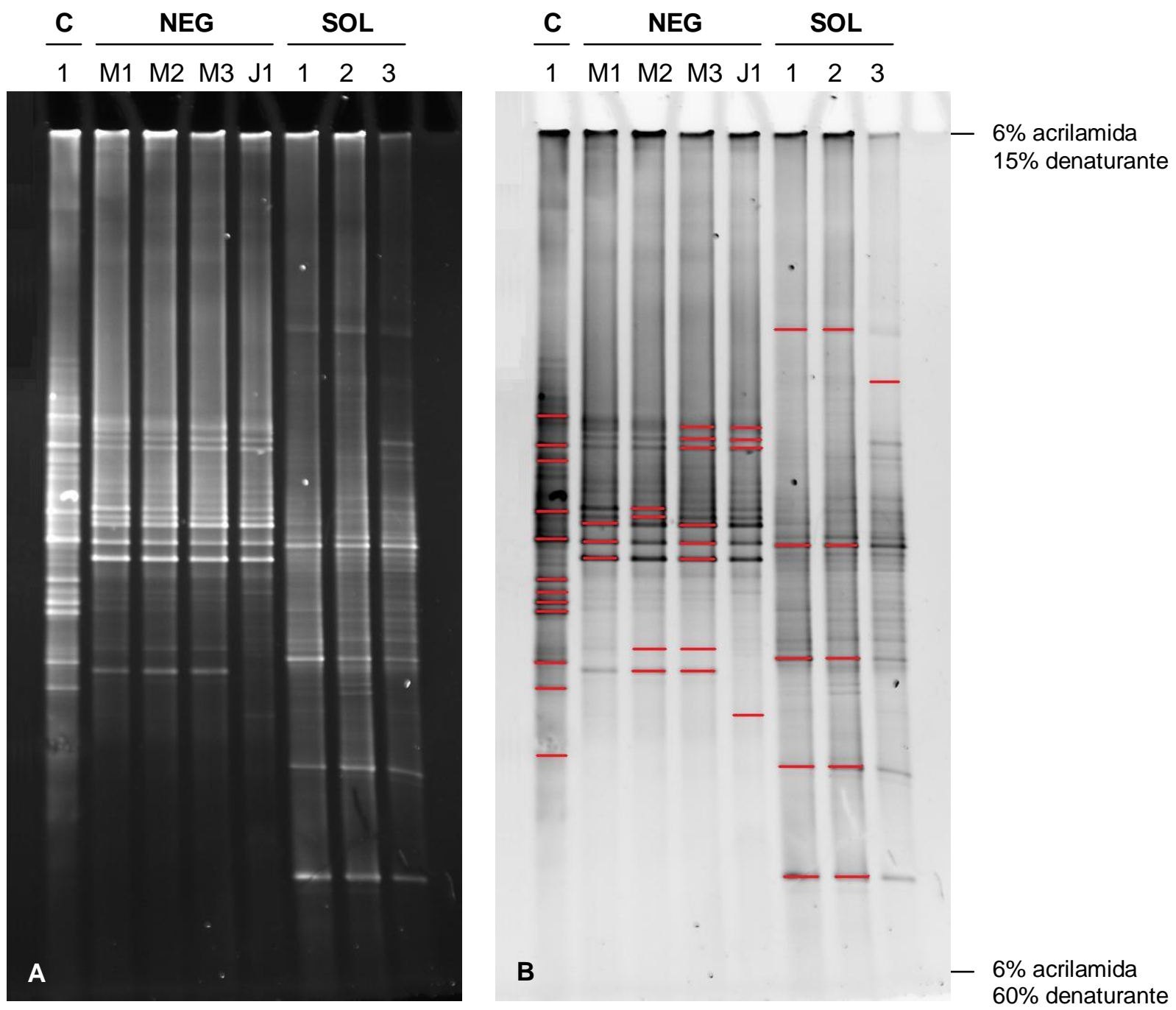

Figura 34. Análise do perfil da comunidade de miofagos por DGGE. Eletroforese em gel de poliacrilamida (6\%), com gradiente denaturante de $15 \%$ a $60 \%$. Alíquotas de $25 \mu \mathrm{L}$ de produto de $P C R$ reamplificado das amostras dos rios Cuieiras (CUI), Negro (NEGM e NEGJ) e Solimões (SOL), corridas a $60{ }^{\circ} \mathrm{C}$ e $60 \mathrm{~V}$ por 20 horas. Gel corado com SYBR Green e visualizado sob luz UV. Em A, imagem real e em B, imagem invertida. Em B, fragmentos marcados em vermelho são os fragmentos clonados e sequenciados.

O padrão eletroforético resultado da DGGE indicou variabilidade entre as amostras dos diferentes rios, suficiente para a identificação da origem de cada amostra baseada apenas na análise visual do perfil. Entretanto, foi observada pouca variação entre as amostras de um mesmo rio (Figura 34), ou seja, apesar de o padrão eletroforético ter indicado diferença na estrutura (riqueza) das comunidades de miofagos dos três rios estudados, não foi constatada variação temporal significativa entre as amostras de um mesmo rio. Talvez alguma variação temporal pudesse ter sido verificada caso as amostras tivessem sido coletadas com intervalos de tempo maiores, como observado por Wang et al. (2009a) em amostras de campos de arroz japoneses, ou, ainda, se tivéssemos comparado essas amostras com outras, coletadas durante a estação de seca. A variação temporal do virioplâncton tem sido analisada em diversos trabalhos que verificaram estar ela associada a fatores 
como sazonalidade (Mathias et al., 1995), ocorrência de florações (Larsen et al., 2008b), diferença na oferta de nutrientes (Ram e Sime-Ngando, 2008) ou, até mesmo, altura da maré e salinidade (Short e Suttle, 2003). Cabe ressaltar que a avaliação da variação temporal do virioplâncton não estava entre os objetivos do trabalho e que a repetição dos perfis, verificada entre as amostras de um mesmo rio, fortaleceu os resultados obtidos da amostra única do rio Cuieiras, no sentido de indicar sua representatividade.

Ainda com base na análise da imagem do gel de $D G G E$, apenas uma pequena variação entre as populações de miofagos presentes nas amostras coletadas à montante (NEGM) e à jusante (NEGJ) de Manaus foi constatada (Figura 35). Tal dado é indicativo de que a descarga constante de efluente doméstico bruto no rio Negro, na região de Educandos, pouco afeta a riqueza da população de miofagos estudada, no local de coleta.

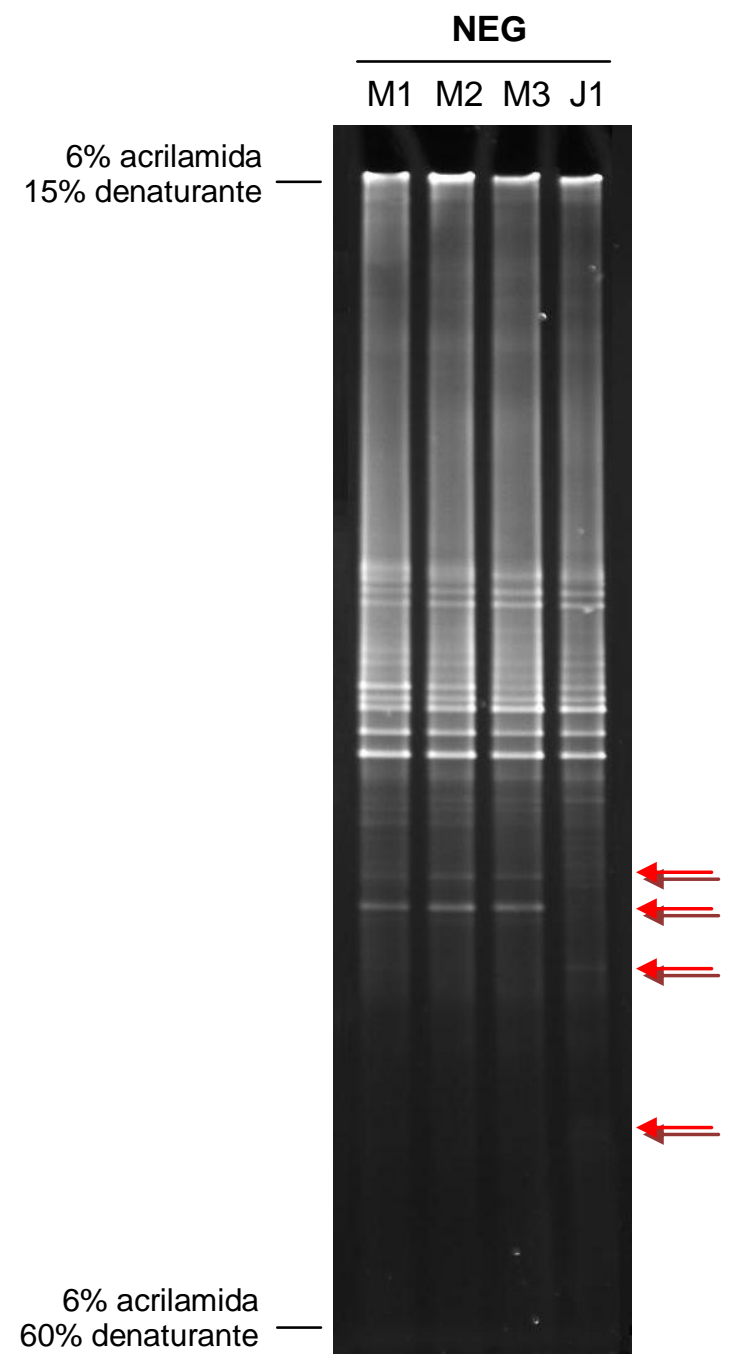

Figura 35. Comparação dos perfis das comunidades de miofagos do rio Negro, à montante e à jusante de Manaus, por DGGE. Eletroforese em gel de poliacrilamida (6\%), com gradiente denaturante de $15 \%$ a $60 \%$. Alíquotas de $25 \mu \mathrm{L}$ de produto de $P C R$ reamplificado das amostras do rio Negro, à montante (M) e à jusante (J) de Manaus, corridas a $60^{\circ} \mathrm{C}$ e 60 V por 20 horas. Gel corado com SYBR Green e visualizado sob luz UV. Setas em vermelho indicam alturas do gel onde houve diferença nos perfis. 78 
Contrariamente ao resultado obtido, esperava-se encontrar significativa diferença na riqueza da comunidade de miofagos à jusante de Manaus, como resposta à poluição pontual da região, a qual introduz grande quantidade de matéria orgânica e bactérias no corpo d'água. Tal hipótese baseava-se no fato de efluentes domésticos serem ricos em bactérias $E$. coli, espécie hospedeira de fagos T4-like, alvo dos oligonucleotídeos utilizados neste estudo (MZIA). Outros fatos que dão embasamento a essa hipótese são a verificação da introdução de vírus patógenos humanos na comunidade viral natural como resultado da descarga de efluente doméstico, relatada na revisão escrita por Griffin et al. (2003), e a constatação do aumento significativo da contagem de vírus entéricos (rotavírus, norovírus, astrovírus humano e adenovírus) na própria região de Educandos, em comparação com áreas menos impactadas, realizada por Miagostovich et al. (2008).

Entretanto, os dados do DGGE corroboram os dados das análises químicas apresentados e discutidos anteriormente (item 5.2), segundo os quais não foi verificada alteração significativa em nenhum dos parâmetros indicadores de poluição analisados (Tabelas 2 e 3 ).

Fica então evidente que, para um entendimento mais completo sobre o impacto do lançamento de efluentes sobre a comunidade viral da região, mostra-se necessária a realização de novos estudos que contemplem um número de amostras estatisticamente apropriado para esse tipo de abordagem, dados de hidrodinâmica, e que tenham um desenho amostral que considere o grande fluxo de água do rio Negro, a elevada velocidade da corrente e processos naturais como o da autodepuração.

\subsubsection{Reconstrução filogenética}

Diferentemente do que foi realizado para ficodnavírus, duas bibliotecas gênicas de miofagos foram construídas: uma, a partir de material retirado do gel de $D G G E$, e outra, diretamente extraída do material amplificado por $P C R$, totalizando 180 sequências, sendo 81 das amostras do rio Negro (NEGM-1, NEGM-2, NEGM-3 e NEGJ-1), 62 das amostras do rio Solimões (SOL-1, SOL-2 e SOL-3) e 37 das amostras do rio Cuieiras (CUI-1).

O alinhamento das sequências de miofagos foi bastante mais complexo que o de ficodnavírus, devido à existência de uma região hipervariável entre os resíduos de aminoácido 164 e 233 (Fokine et al., 2005) (ANEXO I). A presença de inserções e deleções múltiplas na região central das sequências amplificadas resultou em fragmentos de diferentes tamanhos.

A filogenia dos miofagos realizada a partir das sequências de aminoácidos apresentou resultados bastante diferentes da reconstrução filogenética dos ficodnavírus. Miofagos mostraram-se panmíticos, com grande mistura genética entre os ambientes marinho, de água doce e de campos de arroz (Figura 36), em acordo com os dados disponíveis na literatura (Short e Suttle, 2005; Filée et al., 2005; Fujiia et al., 2008). Tal dado já era esperado já que as bactérias hospedeiras da maioria dos fagos estudados (enterobactérias) fazem parte um grupo de micro-organismos muito abundante e 
diverso, e são encontradas nos mais variados ambientes, contrariamente ao fitoplâncton, que possui uma série de restrições frente ao ambiente que ocupa.

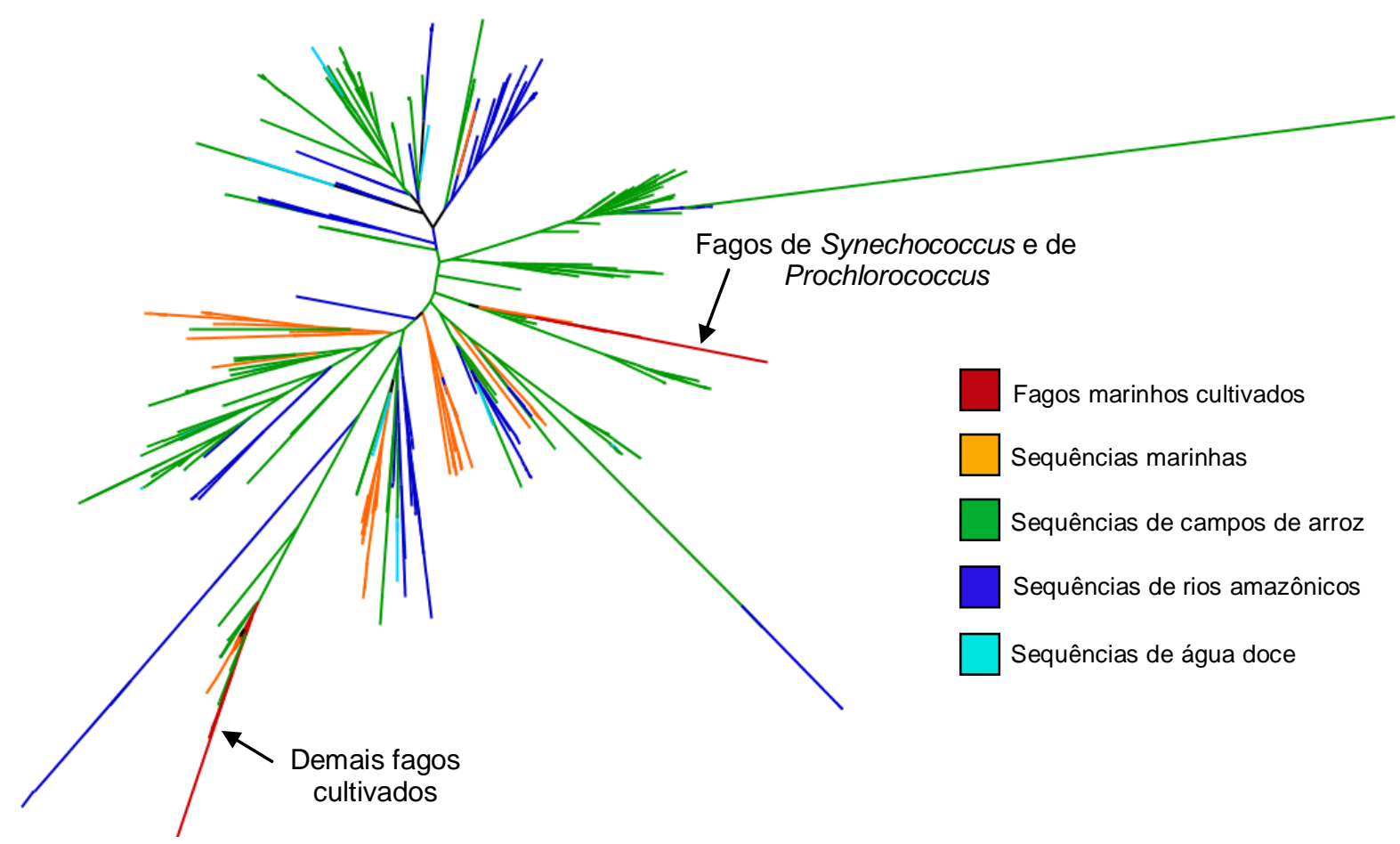

Figura 36. Árvore filogenética (máxima verossimilhança) de miofagos com base na sequência de aminoácidos indica panmixia desses vírus entre os diversos ambientes - marinho, campos de arroz e água doce.

A análise da árvore filogenética também revelou que independentemente do ambiente, clones de miofagos ambientais paressem ser mais proximamente relacionados entre si do que com os fagos cultivados, à semelhança do observado para os ficodnavírus. Os dados também mostraram que todos os fagos marinhos cultivados formaram um único grupo, à exceção dos fagos de Synechococcus e Prochlorococcus, não sendo possível, portanto, a separação dos clones ambientais de acordo com os grupos propostos por Filée et al. (2005). Resultado semelhante a esse foi apresentado por Wang et al. (2009a), que obtiveram 56 sequências referentes ao gene gp23, das quais apenas nove se juntaram aos grupos previamente descritos. Em outro estudo realizado pelos mesmos pesquisadores (Wang et al., 2009b), nenhuma das 53 sequências obtidas foi incluída nesses grupos. Similarmente, Jia et al. (2007) obtiveram 17 sequências, das quais uma foi incluída no grupo T-evens, uma no grupo Schizo T-evens e duas no Exo T-evens. Com base nesse conjunto de estudos, acreditamos que o aparecimento de novos grupos de miofagos, praticamente a cada novo trabalho, seja um indicador da grande diversidade desses agentes e da enorme riqueza ainda inexplorada. 


\subsection{Detecção visual e caracterização morfológica de partículas virais}

Com o objetivo de detectar e analisar a diversidade dos vírus das amostras amazônicas de maneira independente da biologia molecular dos agentes, foram realizados ensaios de MET.

Através dessa técnica, somente foi possível verificar a presença de fagos nas amostras, não tendo sido encontrado nenhum ficodnavírus. Dessa forma, a microscopia não pôde esclarecer as dúvidas sobre a presença desses vírus nas amostras do Rio Negro.

As imagens obtidas revelaram a presença de fagos pertencentes às três famílias Podoviridae (cauda curta), Myoviridae (cauda contrátil) e Syphoviridae (cauda longa) (Figuras 37, 38 e 39), sendo a grande maioria de miofagos, e apenas um podofago e um sifofago.

No Brasil, há poucos estudos sobre a diversidade de fagos presentes naturalmente em ambientes aquáticos (Pedroso e Martins, 1995; Rosero, 2009), dificultando uma avaliação comparativa dos resultados obtidos no presente trabalho. O estudo realizado por Rosero (2009) em ambiente aquático marinho do litoral do estado de São Paulo, em área de atividade antrópica mínima, apresentou resultados diferentes dos observados nos rios amazônicos, revelando a ausência de miofagos e a predominância de sifofagos (75\%). É interessante ressaltar que, segundo essa autora, a detecção de miofagos nas micrografias foi diretamente proporcional ao aumento da atividade antrópica na região amostrada; ou seja, a detecção de miofagos ocorreu somente nas amostras provenientes de regiões com alta atividade antrópica, contrariamente ao resultado obtido com as amostras amazônicas, e em amostras de que mostrou a presença predominante do grupo em corpos d'água com baixo ou sem impacto humano. Em trabalho realizado com águas de superfície e subterrâneas, com diferentes graus de poluição, coletadas no estado de São Paulo, Pedroso e Martins (1995) também não verificaram correlação entre a presença de determinada família viral com a qualidade da água. Cabe lembrar, entretanto, que o estudo realizado por Rosero se utilizou de amostras marinhas, podendo ser esta uma razão para a aparente controvérsia.

As micrografias obtidas mostraram partículas virais com grande variedade morfológica e vários fagos que não se assemelham a nenhum dos disponíveis no banco de dados do ICTVdB, em especial os das Figuras 37C, 38D e 39E, evidenciando a necessidade da realização de um estudo morfológico mais detalhado para a caracterização desses novos vírus encontrados. 


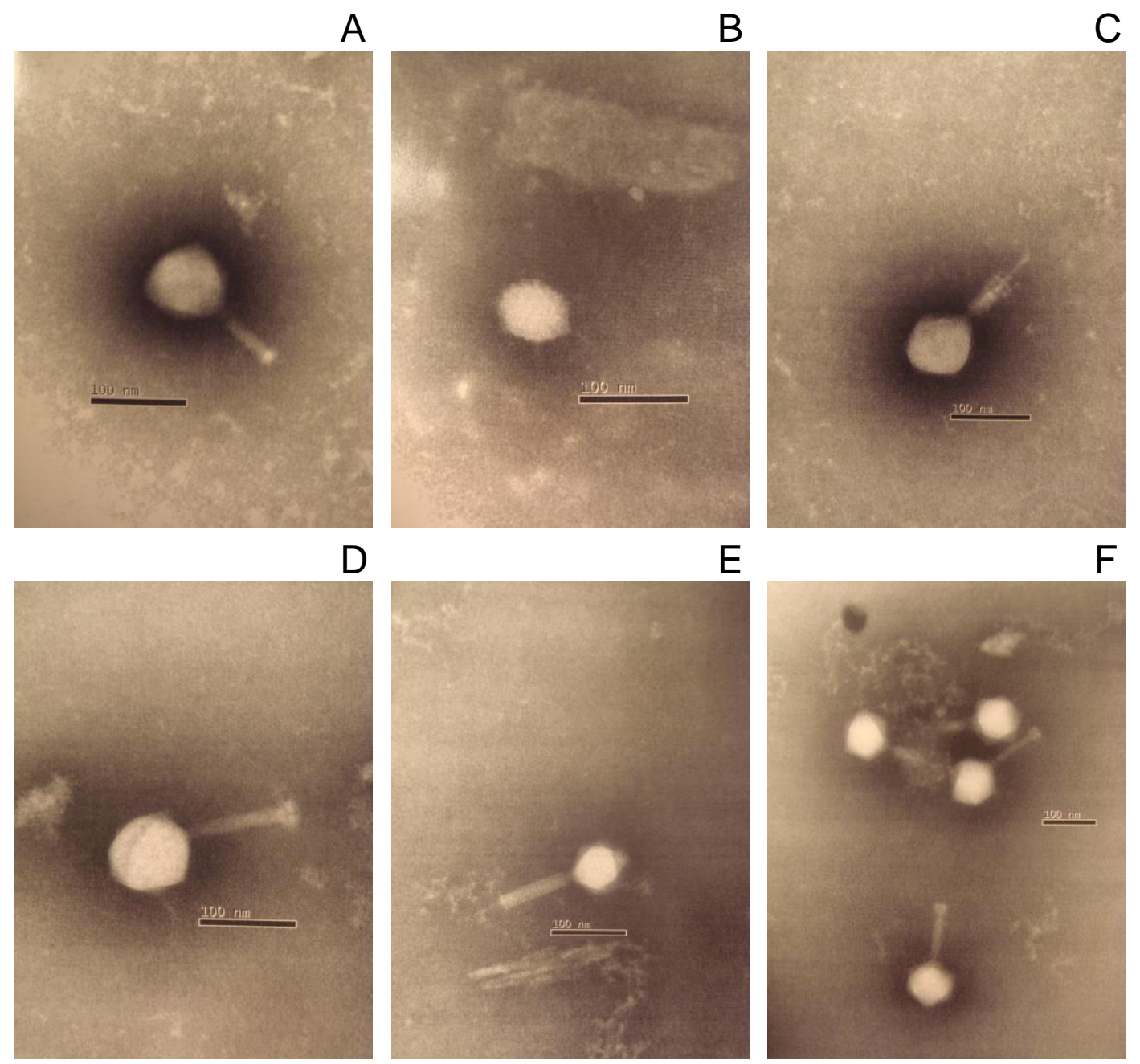

Figura 37. Micrografias eletrônicas da amostra NEGM-1 do rio Negro. Em A, C, D, E e F, fagos da família Myoviridae; em B, partícula viral. 


\section{A}

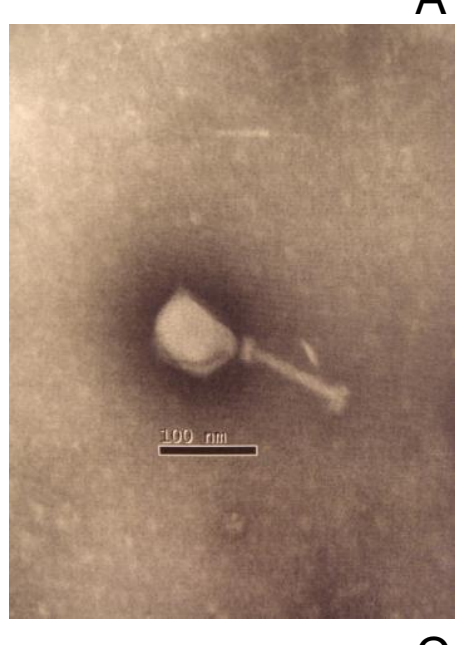

C
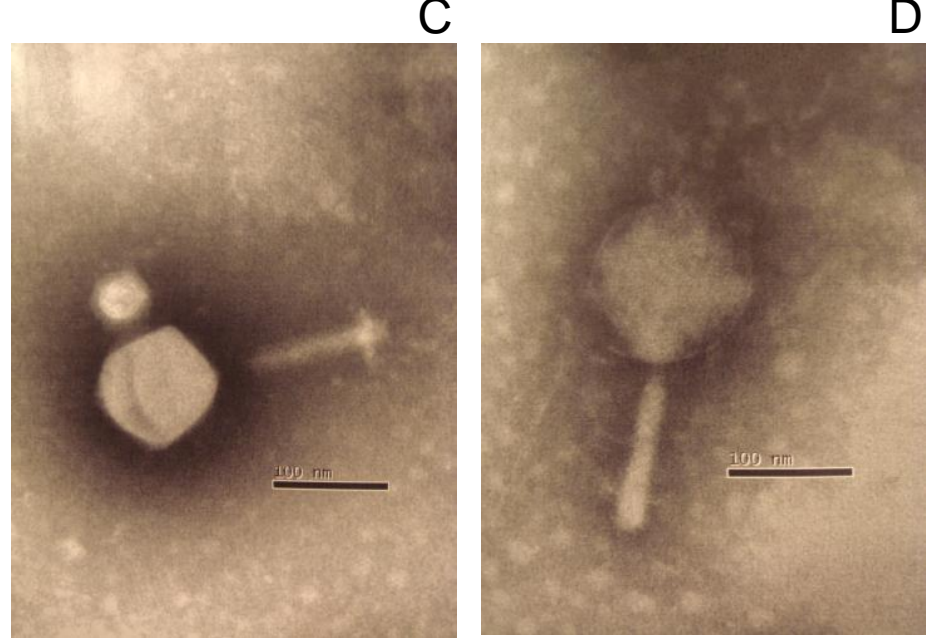

Figura 38. Micrografias eletrônicas da amostra SOL-3 do rio Solimões. Exemplares de fagos da família Myoviridae.

B

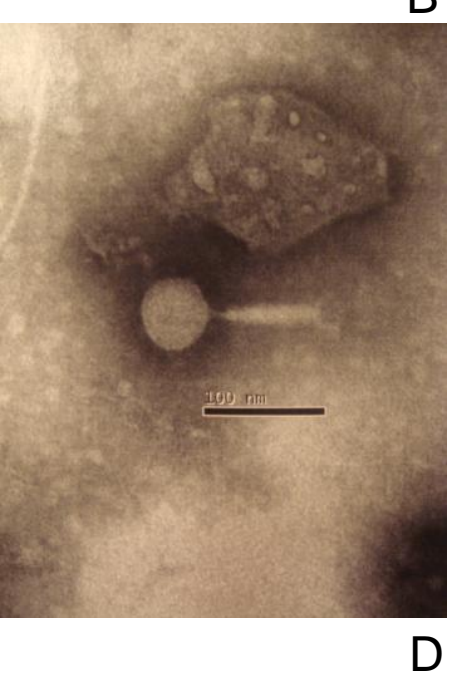

$\mathrm{D}$

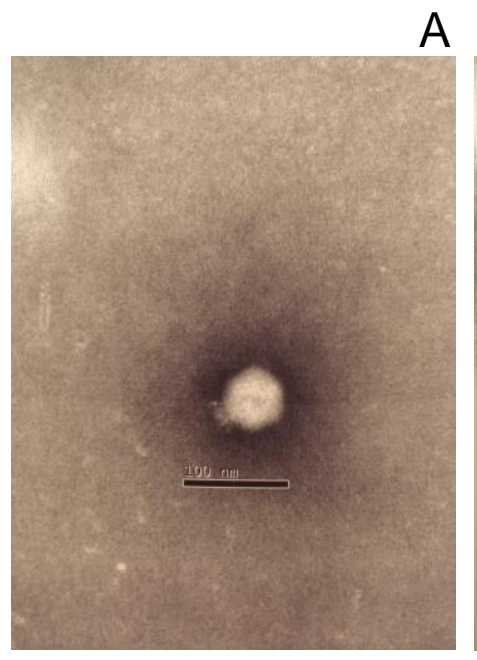

A

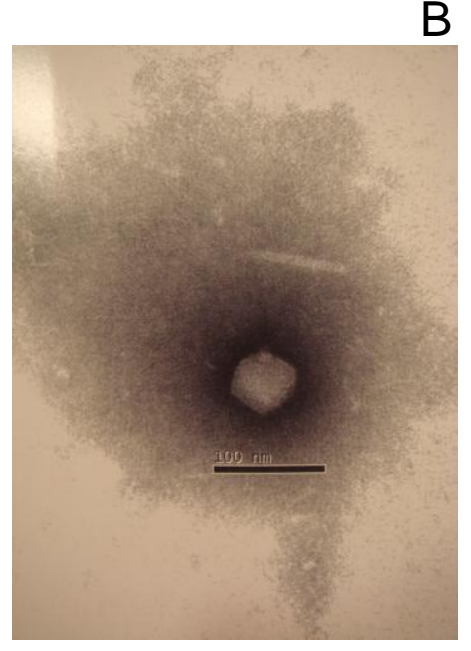

$\mathrm{D}$
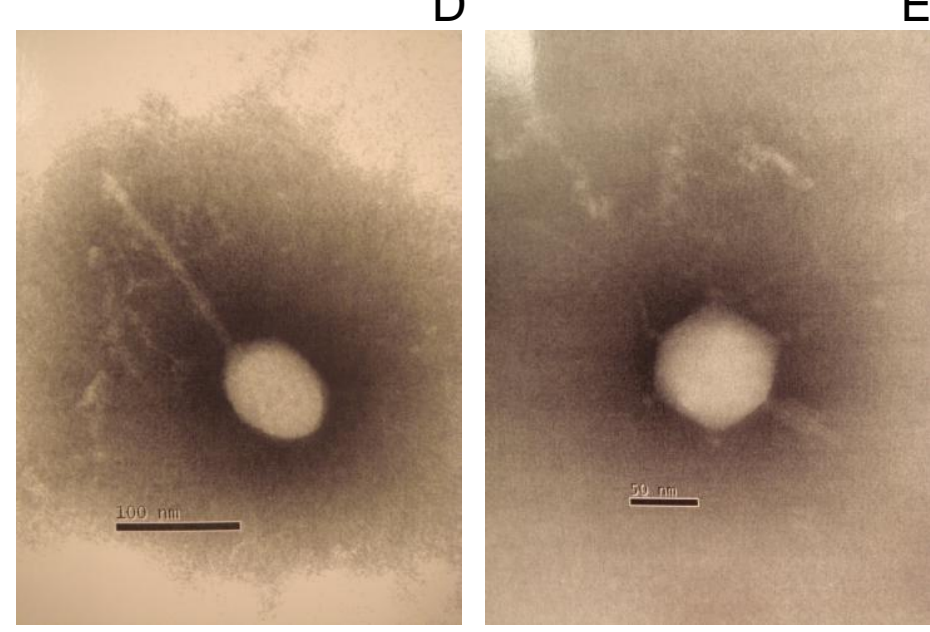

Figura 39. Micrografias eletrônicas da amostra CUI-1 do rio Cuieiras. Em A, fago da família Podoviridae; em B e C, partículas virais; em D, fago da família Syphoviridae; e em E, fago da família Myoviridae.
C

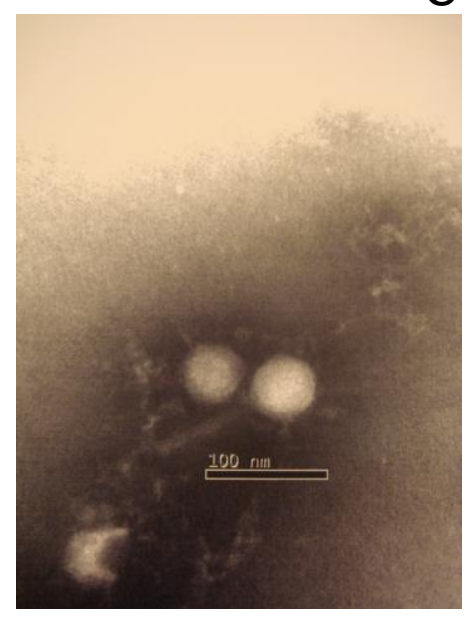

$\mathrm{E}$ 


\section{CONCLUSÕES}

- Os dados físicos e químicos das amostras amazônicas confirmaram sua classificação como "águas-pretas" para os rios Negro e Cuieiras e "águas-brancas" para o Solimões.

- A presença de ficodnavírus nas amostras dos rios Solimões e Cuieiras foi constatada por $P C R$, mas não por MET. Nas amostras do rio Negro a presença desse vírus não foi constatada por nenhum dos métodos.

- A presença de miofagos em todas as amostras dos rios Negro, Cuieiras e Solimões foi constatada tanto por PCR quanto por MET.

- O perfil eletroforético da população de miofagos foi característico para cada rio e mostrou-se constante nas amostras de um mesmo rio. Tal caracterização, porém, não foi possível para ficodnavírus.

- Foi gerado um banco de dados com 104 sequências de ficodnavírus e 180 sequências de miofagos, originárias dos rios amostrados.

- O estudo filogenético de ficodnavírus revelou que os clones provenientes de ambientes de água doce são mais proximamente relacionados com os vírus marinhos $M p V, B p V e$ $O s V$ do que com o vírus $P B C V$-1, também de água doce, e que os clones ambientais agrupam-se em clados distintos dos de vírus isolados.

- O estudo filogenético de miofagos revelou que estes não se agrupam em função das características do ambiente nem da localidade, havendo uma relação mais próxima entre os clones ambientais do que com os fagos isolados.

- Os ficodnavírus não são panmíticos em relação ao ambiente que ocupam. Verificou-se fluxo gênico entre os ambientes lótico e lêntico, e do marinho para os de água doce, mas não o contrário.

- O estudo filodinâmico revelou que o número de populações de ficodnavírus variou no último 1,5 milhão de anos, alcançando seu mínimo no período de 500 a 300 mil anos atrás, seguido de recuperação até o presente.

- Os grupos de fitoplâncton encontrados nas amostras analisadas referendam os dados da literatura.

- A interferência do lançamento de efluentes domésticos sobre as características da água e sobre as populações locais virais das famílias Phycodnaviridae e Myoviridae e fitoplanctônicas não foi observada, apesar de ter sido sugerida pela diminuição do número de táxons de fitoplâncton. 


\section{REFERÊNCIAS*}

Adams MH. Bacteriophages. New York, NY: Wiley-Interscience; 1959.

Altschul SF, Gish W, Miller W, Myers, EW, Lipman DJ. Basic local alignment search tool. J Mol Biol. 1990;215:403-410.

American Public Health Association; American Water Work Association - AWWA; Water Pollution Control Federation - WPCF. Standard Methods of the Experimentation of Water and Wastewater. 14th ed. New York: APHA; 1985.

Anesio AM, Hollas C, Granéli W, Laybourn-Parry J. Influence of humic substances on bacterial and viral dynamics in freshwaters. Appl Environ Microbiol. 2004;70:4848-4854.

Armstrong HA, Brasier MD. Microfossils. 2nd ed. Oxford: Blackwell; 2005.

Azam F, Fenchel T, Field JG, Gray JS, Meyer Reil LA, Thingstad F. The ecological role of watercolumn microbes in the sea. Mar Ecol Prog Ser. 1983;10:257-263.

Baker AC, Goddard VJ, Davy J, Schoroeder DC, Adams DG, Wilson WH. Identification of a diagnostic marker to detect freshwater cyanophages of filamentous cyanobacteria. Appl Environ Microbiol. 2006;72:5713-5719.

Baud A, Magaritz M, Holser WT. Permian-Triassic of the Tethys - Carbon isotope studies. Geol Rundsch. 1989;78:649-677.

Bellec L, Grimsley N, Moreau H, Desdevises Y. Phylogenetic analysis of new Prasinoviruses (Phycodnaviridae) that infect the green univellular algae Ostreococcus, Bathycoccus and Micromonas. Environ Microbiol Reports. 2009;1:114-123.

Benner R, Opsahl S, Chin-Leo G, Richey JE, Forsberg BR. Bacterial carbon metabolism in the Amazon river system. Limnol Oceanogr. 1995;40:1262-1270.

Bergh O, Borsheim KY, Bratbak G, Heldal M. High abundance of viruses found in aquatic environments. Nature. 1989;340:467-468.

Bettarel Y, Kan J, Wang K, Williamson KE, Cooney S, Ribblett S, Chen F, Wommack KE, Coats DW. Isolation and preliminary characterization of a small nuclear inclusion virus infecting the diatoms Chaetoceros cf. gracilis. Aquat Mar Ecol. 2005;40:103-114.

Bitton G, Mitchell R. Effect of colloids on the survival of bacteriophages in seawater. Water Res. 1974;8:227-229.

Bowring SA, Erwin DH, Jin YG, Martin MW, Davidek K, Wang W, Baud A, Magaritz M, Holser WT. $\mathrm{U} / \mathrm{Pb}$ zircon geochronology and tempo of the End-Permian mass extinction. Science. 1998;280:10391045.

Borsheim KY. Native marine bacteriophages. FEMS Microbiol Ecol. 1993;102:141-159.

Bratbak G, Heldal M, Norland S, Thingstad TF. Viruses as partners in spring bloom microbial trophodynamics. Appl Environ Microbiol. 1990;56:1400-1405.

Bratbak G, Thingstad F, Heldal M. Viruses and the microbial loop. Microb Ecol. 1994;28:209-221.

Brussaard CPD, Kempers RS, Kop AJ, Riegman R, Heldal M. Virus-like particles in a summer bloom of Emiliania huxleyi in the North Sea. Aquat Microb Ecol. 1996;10:105-113.

${ }^{*}$ De acordo com: International Committee of Medical Journal Editors. Uniform requirements for manuscripts submitted to Biomedical Journal: sample references. Available from: http://www.icmje.org [2007 May 22]. 
Brussaard CPD, Marie D, Bratbak G. Flow cytometric detection of viruses. J Virol Methods. 2000; 85:175-182.

Brussaard CPD. Viral control of phytoplankton populations - a review. J Eukaryot Microbiol. 2004a;51:125-138.

Brussaard CPD. Optimization of procedures for counting viruses by flow cytometry. Appl Environ Microbiol. 2004b;70:1506-1513.

Campbell IH, Czamanske GK, Fedorenko VA, Hill RL, Stepanov V, Synchronism of the Siberian Traps and the Permian-Triassic boundary. Science. 1992;258:1760-1763.

Castberg TA, Larsen A, Sandaa RA, Brussaard CPD, Egge JK, Heldal M, Thyrhaug R, Van Hannen EJ, Bratbak G. Microbial population dynamics and diversity during a bloom of the marine coccolithophorid Emiliania huxleyi (Haptophyta). Mar Ecol Prog Ser. 2001;221:39-46.

Chao L, Levin BR, Steward FM. A complex community in a simple habitat: An experimental study with bacteria and phage. Ecology. 1977;58:369-378.

Chen F, Suttle CA. Nested $P C R$ with 3 highly degenerate primers for amplification and identification of DNA from related organisms. Biotechniques. 1995;18:609-612.

Chen F, Suttle CA, Short SM. Genetic diversity in marine algal virus communities as revealed by sequence analysis of DNA polymerase genes. Appl Environ Microbiol. 1996;62:2869-2874.

Chen F, Suttle CA. Evolutionary relationships among large double-stranded DNA viruses that infect microalgae and other organisms as inferred from DNA polymerase genes. Virology. 1996;219:170178.

Chénard C, Suttle CA. Phylogenetic diversity of sequences of cyanophage photosynthetic gene psbA in marine and freshwaters. Appl Environ Microbiol. 2008;74:5317-5324.

Chiura HX. Generalized gene transfer by virus-like particles from marine bacteria. Aquat Microb Ecol. 1997;13:75-83.

Cissoko MM, Desnues A, Bouvy M, Sime-Ngando TL, Verling E, Bettarel Y. Effects of freshwater and seawater mixing on vireo and bacterioplankton in a tropical estuary. Freshwater Biol. 2008;53:11541162.

Clasen JL, Brigden SM, Payet JP, Suttle CA. Evidence that viral abundance across oceans and lakes is driven by different biological factors. Freshwater Biol. 2008;3:1090-1100.

Clasen JL, Suttle CA. Identification of freshwater Phycodnaviridae and their potential phytoplankton hosts, using DNA pol sequence fragments and a genetic-distance analysis. Appl Environ Microbiol. 2009;75:991-997.

Cochlan WP, Wikner J, Steward GF, Smith DC, Azam F. Spatial distribution of viruses, bacteria and chlorophyll a in neritic, oceanic and estuarine environments. Mar Ecol Prog Ser. 1993;92:77-87.

Cochran PK, Paul JH. Seasonal abundance of lysogenic bacteria in a subtropical estuary. Appl Environ Microbiol. 1998;64:2308-2312.

Coleman ML, Sullivan MB, Martiny AC, Steglich C, Barry K, Delong EF, Chisholm SW. Genomic islands and the ecology and evolution of Prochlorococcus. Science. 2006;311:1768-1770.

Colombet J, Sime-Ngando T, Cauchie HM, Fonty G, Hoffmann L, Demeure G. Depth-related gradients of viral activity in lake Pavin. Appl Environ Microbiol. 2006;72:4440-4445.

Conselho Nacional do Meio Ambiente - Resolução n³57. Ministério do Meio Ambiente. 17 de março de 2005. 
Cottrel MT, Suttle CA. Wide-spread occurrence and clonal variation in viruses which cause lysis of a cosmopolitan eukaryotic marine phytoplankter, Micromonas pusilla. Mar Ecol Prog Ser. 1991;78:1-9.

Culley Al, Lang AS, Suttle CA. The complete genomes of three viruses assembled from shotgun libraries of marine RNA virus communities. Virol J. 2007;4:69.

Cunha HB, Pascoalato D. Hidroquímica dos rios da Amazônia. Governo do Estado do Amazonas, Secretaria de Estado da Cultura: CCPA; 2006.

Danovaro R, Corinaldesi C, Filippini M, Fischer UR, Gessner MO, Jacquet S, Magagnini M, Velimiro VB. Viriobenthos in freshwater and marine sediments: a review. Freshwater Biol. 2008;53:1186-1213.

Davy JE, Patten NL. Morphological diversity of virus-like particles within the surface microlayer of scleractinian corals. Aquat Microb Ecol. 2007;47:37-44.

De Paula VS, Diniz-Mendes L, Villar LM, Luz SLB, Silva LA, Jesus MS, da Silva NMVS, Gaspar AMC. Hepatitis A virus in environmental water samples from the Amazon Basin. Water Res. 2007;41:11691176.

Denman KL, Brasseur G, Chidthaisong A, Ciais P, Cox P, Dickinson RE, et al. In: Solomon S, Qin D, Manning M, Marquis M, Averyt K, Tignor MMB, Miller HLR, Chen Z, editors. Climate Change $2007-$ The Physical Science Basis. Cambridge: Cambridge University Press; 2007. p. 499-587.

Desikachary TV. Cyanophyta. New Delhi: Indian Council of Agricultural Research; 1959.

Desnues C, Rodriguez-Brito B, Rayhawk S, Kelley S, Tran T, Haynes M, Liu H, Furlan M, et al. Biodiversity and biogeography of phages in modern stromatolites and thrombolites. Nature. 2008;452:340-345.

Díaz-Castro JG, Souza-Mozimann RM, Laudares-Silva R, Forsberg BR. Composição da comunidade de diatomáceas perifíticas do Rio Jaú, Amazonas, Brasil. Acta Amaz. 2003;3:583-606.

Drummond AJ, Rambaut A. BEAST: Bayesian evolutionary analysis by sampling trees. BMC Evol Biol. 2007;7:214

Dunigan DD, Fitzgeraldy LA, Van Etten JL. Phycodnaviruses: a peek at genetic diversity. Virus Research. 2006;117:119-132.

Erwin DH. The Great Paleozoic Crisis: Life and Death in the Permian. New York: Columbia University Press; 1993.

Ettl H, Gerloff J, Heyning H. et al. Suesswasserflora Von Mitteleuropa (Freshwater flora of Central Europe). Stuttgart:Gustav Fischer Verlag; 1978. 1-19 vol.

Felsenstein J. Phylogenies from molecular sequences: inference and reliability. Annu Rev Genet. 1988;22:521-65.

Felsenstein J. Inferring Phylogenies. 2nd ed. Sunderland, Massachussets: Sinauer Associates; 2004.

Fensome RA, Taylor FJR, Norris G, Sarjeant WAS, Wharton DI, Williams GL. A Classification of Living and Fossil Dinoflagellates. Hanover: Sheridan Press; 1993.

Ferguson N, Anderson R, Gupta S. The effect of antibody-dependent enhancement on the transmission dynamics and persistence of multiple-strain pathogens. Proc Natl Acad Sci. 1999;96:790-794.

Ferrari VC, Hollibaugh JT. Distribution of microbial assemblages in the Central Arctic Ocean Basin studied by PCR/DGGE: analysis of a large data set. Hydrobiologia. 1999;401:55-68. 
Ferreira FF, Guimarães FR, Fumian TM, Victoria M, Vieira CB, Luz S, et al. Environmental dissemination of group A rotavirus: P-type, G-type and subgroup characterization. Water Sci Technol. 2009;60:633-42.

Ferris MJ, Muyzer G, Ward DM. Denaturing gradient gel electrophoresis profiles of $15 \mathrm{~S}$ rRNA-defined populations inhabiting a hot spring microbial mat community. Appl Environ Microbiol. 1996;62;340346.

Filée J, Tétart F, Suttle CA, Krisch HM. Marine T4-type bacteriophages, a ubiquitous component of the dark matter of the biosphere. Proc Natl Acad Sci. 2005;102:12471-12476.

Filippini M, Buesing N, Gessner MO. Temporal dynamics of freshwater bacterio- and virioplankton along a littoral-pelagic gradient. Freshwater Biology. 2008;53:1114-1125.

Fischer SG, Lerman LS. Length-independent separation of DNA restriction fragments in twodimensional gel electrophoresis. Cell. 1979;16:191-200.

Fokine A, Leiman PG, Shneider MM, Ahvazi B, Boeshans KM, Steven AC, Black LW, Mesyanzhinov VV, Rossmann MG. Structural and functional similarities between the capsid proteins of bacteriophages T4 and HK97 point to a common ancestry. Proc Natl Acad Sci. 2005;102: 7163-7168.

Förster K. Amazonische desmidien. Amazoniana. 1969;2:5-116.

Fuhrman J. Bacterioplankton roles in cycling of organic matter: the microbial food web. In: Falkowski PG, Woodhead AD, editors. Primary productivity and biogeochemical cycles in the sea. New York: Plenum Press; 1992. p. 361-383.

Fuhrman JA, Suttle CA. Viruses in marine planktonic systems. Oceanography. 1993;6:51-63.

Fuhrman JA. Marine viruses and their biogeochemical and ecological effects. Nature. 1999;399:541548.

Fujii T, Nakayama N, Nishida M, Sekiya H, Kato N, Asakawa S, Kimura M. Novel capsid genes (g23) of T4-type bacteriophages in a Japanese paddy field. Soil Biol Biochem. 2008;40:1049-1058.

Fuller NJ, Wilson WH, Joint IR, Mann NH. Occurrence of a sequence in marine cyanophages similar to that of T4 gp2O and its application to PCR-based detection and quantification techniques. Appl Environ Microbiol. 1998;64:2051-2060.

Gago S, Elena SF, Flores R, Sanjuán R. Extremely high mutation rate of a hammerhead viroid. Science. 2009;323:1308.

Garza DR, Suttle CA. Large double-stranded DNA viruses which cause the lysis of marine heterotrophic nanoflagellates occur in natural marine virus communities. Aquat Microbiol. 1995;9:203210.

Gill ML, Nealson K. Isolation and host range studies of marine bacteriophage. Biol Bull. 1972;143:463464.

Gimenes MV, Gianesella SM, Borella MI, Nunes AF, Garrafa P, Monezi TA, Mehnert DU. Viral diversity assessment at the Guarapiranga reservoir - Sao Paulo, Brazil. In: Virus ecology in marine systems - A workshop on methods, 2006, Vancouver, Canada.

Gobler CJ, Hutchins DA, Fisher NS, Cosper EM, Sanudo-Wilhelmy AS. Release and bioavailability of C, N, P, Se and Fe following viral lysis of a marine chrysophyte. Limnol Oceanogr. 1997;42:14921504.

Gonzales JM, Suttle CA. Grazing by marine nanoflagellates on viruses and virus-sized particlesingestion and digestion. Mar Ecol Prog Ser. 1993;94:1-10. 
Gradstein FM, Ogg JG, Smith AG. A Geologic Time Scale 2004. Cambridge: Cambridge University Press; 2005.

Griffin DW, Donaldson KA, Paul JH, Rose JB. Pathogenic human viruses in coastal waters. Clinical Microbiol Rev. 2003;16:129-143.

Guindon S, Gascuel O. A simple, fast, and accurate algorithm to estimate large phylogenies by maximum likelihood. Systematic Biology. 2003;52:696-704.

Guixa-Boixereu N, Vaque D, Gasol JM, Sanchez-Camara J, Pedros-Alio C. Viral distribution and activity in Antarctic waters. Deep-Sea Res. 2002;49:827-845.

Hara S, Terauchi K, Koike I. Abundance of viruses in marine waters: assessment by epifluorescence and transmission electron microscopy. Appl Environ Microbiol. 1991;57:2731-2734.

Hara S, Koike I, Terauchi K, Kamiya H, Tanoue E. Abundance of viruses in deep oceanic waters. Mar Ecol Prog Ser. 1996;145:269-277.

Harris JW, Stocker H. Handbook of Mathematics and Computational Science. New York: SpringerVerlag; 1998.

Heldal M, Bratbak G. Production and decay of viruses in aquatic environments. Mar Ecol Prog Ser. 1991;72:205-212.

Hendey NI. An introductory account of the smaller algae of British coastal waters. Part V Bacillariophyceae (Diatoms). London: H.M. Stationery Office; 1964.

Hennes KP, Suttle CA. Direct counts of viruses in natural waters and laboratory cultures by epifluorescence microscopy. Limnol Oceanogr. 1995;40:1050-1055.

Henning W. Phylogenetic systematic. Urbana: University of Illinois Press; 1966.

Hewson I, O'Neil JM, Fuhrman JA, Dennison WC. Virus-like particle distribution and abundance in sediments and overlying waters along eutrophication gradients in two subtropical estuaries. Limnol Oceanogr. 2001;46:1734-1746.

Hewson I, Capone DG, Steele JA, Furhman JA. Influence of Amazon and Orinoco offshore surface water plumes on oligotrophic bacterioplankton diversity in the west tropical Atlantic. Aquat Microb Ecol. 2006;43:11-22.

Hill RW, White BA, Cottrell MT, Dacey JWH. Virus-mediated total release of dimethylsulfoniopropionate from marine phytoplankton: a potential climate process. Aquat Microb Ecol. 1998;14:1-6.

Honjo MN, Minamoto T, Matsui K, Uchii K, Yamanaka H, Suzuki AA, Kohmatsu Y, lida T, Kawabata Z. Quantification of cyprinid herpesvirus 3 in environmental water by using an external standard virus. Appl Environ Microbiol. 2010;76:161-168.

Houghton RA. Balancing the global carbon budget. Annu Rev Earth PI Sc. 2007;35:313-347.

Huber-Pestalozzi G. Das Phytoplankton des Süsswassers: Systematik und Biologie. vol. 4. Euglenophyceen. Stuttgart: E. Schweizerbart'sche Verlagsbuchhandlung; 1955.

Huber-Pestalozzi G. Das Phytoplankton des Süßswassers. Systematik und Biologie. vol. 5. Chlorophyceae. Stuttgart: E. Schweizerbart'sche Verlagsbuchhandlung; 1961.

Huber-Pestalozzi G. Das Phytoplankton des Süsswassers: Systematik und Biologie. vol. 2. Chrysophyceeen. Stuttgart: E. Schweizerbart'sche Verlagsbuchhandlung; 1962. 
Huelsenbeck JP, Rannala B, Larget B. A Bayesian framework for the analysis of cospeciation. Evolution. 2000;54:352-64.

Hungria M, Astolfi-Filho S, Chueire LMO, Nicola's MF, Santos EBP, Bulbol MR, Souza-Filho A, et al. Genetic characterization of Chromobacterium isolates from black water environments in the Brazilian Amazon. Appl Microbiol. 2005;41:17-23.

Hustedt F. Die Kieselalgen Deutschlands, Österreichs und der Schweiz mit Berücksichtigung der übrigen Lãndern Europas sowie der angrenzenden Meeresgebiete. In: Rabenhorst L. Kryptogamenflora. 1927-1966;7(3):1-816.

Hustedt F. Neue und wenig bekannte Diatomeen. VII Ber Deutsch Bot Ges. 1955;68:121-132.

Hustedt F. Die Kieselalgen. Koenigstein: Koeltz; 1985. The Pennate Diatoms; p.918. 2. Vol.

Hutchinson GE. The paradox of the plankton. Am Nat. 1961;95:137-145.

Jackson EF, Jackson CR. Viruses in wetland ecosystems. Freshwater Biology. 2008;53:1214-1227.

Jia Z, Ishihara R, Nakajima Y, Asakawa S, Kimura M. Molecular characterization of T4-type bacteriophages in a rice field. Environ Microbiol. 2007;9:1091-1096.

Jiang SC, Paul JH. Gene transfer by transduction in the marine environment. Appl Environ Microbiol. 1998;64:2780-2787.

Jones DT, Taylor WR, Thornton JM. The rapid generation of mutation data matrices from protein sequences. CABIOS. 1992;8:275-282.

Kan J, Hanson TE, Ginter JM, Wang K, Chen F. Metaproteomic analysis of Chesapeake Bay microbial communities. Saline Systems. 2005;1:7.

Kang M, Dunigan DD, Van Etten JL. Chlorovirus: a genus of Phycodnaviridae that infects certain chlorella-like green algae. Mol Plant Pathology. 2005;6:213-224.

Kellogg CA, Rose JB, Jiang SC, Thurmond J, Paul JH. Genetic diversity of related vibriophages isolated from marine environments around Florida and Hawaii, USA. Mar Ecol Prog Ser. 1995;120: 89-98.

Khan S, Arakawa O, Onoue Y. Neurotoxins in a toxic red tide of Heterosigma akashiwo (Raphidophyceae) in Kagoshima Bay, Japan. Aquaculture Research. 1997;28:9-14.

Kirst CO. Salinity tolerance of eukaryotic marine algae. Annu Rev Plant Physiol Plant Mol Biol. 1989;40:21-53.

Kisielius JJ. Detecção de vírus causadores de gastroenterites por técnicas de microscopia eletrônica [tese (Doutorado em Microbiologia)]. São Paulo: Instituto de Ciências Biomédicas da Universidade de São Paulo; 1998.

Knipe DM, Howley PM. Fields Virology. 5th ed. Lippincott Williams \& Wilkins; 2007.

Komárek J, Fott B. Chlorophyta - Chlorococcales. In: Huber-Prestalozzi G. Euglenophyta. In: Das Phytoplankton des Süsswassers. Systematik und Biologie. Systematik und Biologie. Stuttgart: E. Schweizerbart'sche Verlagsbuchlandlung. pt. 7, 1044 p. (Die Binnengewässer, August Thienemann), 1983.

Komárek J, Anagnostidis K. Süßwasserflora von Mitteleuropa, Cyanoprokaryota. 2nd ed. Part: Oscillatoriales. 2005;19(2). 
Kosmala S, Milanowski R, Brzóska K, Pekala M, Kwiatowski J, Zakry's B. Phylogeny and systematics of the genus Monomorphina (Euglenaceae) based on morphological and molecular data. J Phycol. 2007;43:171-185.

Krammer K, Lange-Bertalot H. Bacillariophyceae: Naviculaceae. In: Ettl H, Gerloff J, Heynig H, Mollenhauer D, editors. Süßwasserflora von Mitteleuropa. Stuttgart: Gustav Fischer Verlag; 1986.

Krammer K, Lange-Bertalot H. Süßwasserflora von Mitteleuropa. Bacillariophyceae 1. Teil, Naviculaceae. In: Ettl H, Gerloff J, Heynig H, Mollenhauer D, editors. Süßwasserflora von Mitteleuropa. Stuttgart \& New York: Fischer; 1988; 2 (2).

Krammer K, Lange-Bertalot $\mathrm{H}$. Bacillariophyceae: Achnanthaceae. Kritische Ergänzungen zu Navicula (Lineolatae) und Gomphonema. In: Ettl H, Gärtner G, Gerloff J, Heynig H, Mollenhauer D, editors. Süßwasserflora von Mitteleuropa. Stuttgart: Gustav Fischer Verlag; 1991. 2 vol.

Labonté JM, Reid KE, Suttle CA. Phylogenetic analysis indicates evolutionary diversity and environmental segregation of marine podovirus DNA polymerase gene sequences. Appl Environ Microbiol. 2009;75:3634-3640.

Larsen A, Castberg T, Sandaa RA, Brussaard CPD, Egge J, Heldal M, Paulino A, Thyrhaug R, van Hannen EJ, Bratbak G. Population dynamics and diversity of phytoplankton, bacteria and viruses in a seawater enclosure. Mar Ecol Prog Ser. 2001; 221:47-57.

Larsen JB, Larsen A, Bratbak G, Sandaa RA. Phylogenetic analysis of members of the Phycodnaviridae virus family, using amplified fragments of the major capsid protein gene. Appl Environ Microbiol. 2008a;74: 3048-3057.

Larsen JB, Larsen A, Thyrhaug R, Bratbak G, Sandaa RA. Response of marine viral populations to a nutrient induced phytoplankton bloom at different $\mathrm{pCO}(2)$ levels. Biogeosciences. 2008b;5:523-533.

Lawrence JE, Chan AM, Suttle CA. Viruses causing lysis of the toxic bloom-forming alga Heterosigma akashiwo (Raphidophyceae) are widespread in coastal sediments of British Columbia, Canada. Limnol Oceanogr. 2002;47:545-550.

Leiman PG, Kanamaru S, Mesyanzhinov, Arisaka F, Rossmann MG. Structure and morphogenesis of bacteriophage T4. CMLS Cell Mol Life Sci. 2003;60:2356-2370.

Lenski RE, Levin BR. Constraints on the coevolution of bacteria and virulent phage: a model, some experiments, and predictions for natural communities. Am Nat.1985;125:585-602.

Lenski RE. Dynamics of interactions between bacteria and virulent bacteriophage. Adv Microb Ecol. $1988 ; 10: 1-44$

Levin BR, Steward FM, Chao L. Resource limited growth, competition, and predation: A model and experimental studies with bacteria and bacteriophage. Am Nat. 1977;111:3-24.

Leroy $\mathrm{M}$, Prigent M, Dutertre M, Confalonieri F, DuBow M. Bacteriophage morphotype and genome diversity in Seine River sediment. Freshwater Biol. 2008;53:1176-1185.

Lindell D, Sullivan MB, Johnson ZI, Tolonen AC, Rohwer F, Chisholm SW. Transfer of photosynthesis genes to and from Prochlorococcus viruses. Proc Natl Acad Sci. 2004;101:11013-11018.

Lionard M, Muylaert K, Gansbeke DV, Vyverman W. Influence of changes in salinity and light intensity on growth of phytoplankton communities from the Schelde river and estuary (Belgium/The Netherlands). Hydrobiologia. 2005; 540:105-115.

Lymer D, Lindström ES, Vrede KA. Variable importance of viral-induced bacterial mortality along gradients of trophic status and humic content in lakes. Freshwater Biol. 2008a;53:1101-1113. 
Lymer D, Logue BJ, Brussaard CPD, Baudoux AC, Vrede K, Lindström ES. Temporal variation in freshwater viral and bacterial community composition. Freshwater Biol. 2008b;53:1163-1175.

MacLeod RA. The question of the existence of specific marine bacteria. Bacteriol Rev.1965;29:2-23.

Madan NJ, Marshall WA, Laybourn-Parry J. Virus and microbial loop dynamics over an annual cycle in three contrasting Antarctic lakes. Freshwater Biol. 2005;50:1291-1300.

Madigan MT, Martinko JM, Parker J. Brock biology of microorganisms. 9th ed. London: Printice-Hall; 2000.

Malin G, Wilson WH, Bratbak G, Liss PS, Mann NH. Elevated production of dimethylsulfide resulting from viral infection of cultures of Phaeocystis pouchetii. Limnol Oceanogr. 1998;43:1389-1393.

Maranger R, Bird DF, Juniper SK. Viral and bacterial dynamics in Arctic sea ice during the spring algal bloom near Resolute, N.W.T., Canada. Mar Ecol Prog Ser. 1994;111:121-127.

Maranger R, Bird DF. Viral abundance in aquatic systems: a comparison between marine and fresh waters. Mar Ecol Prog Ser. 1995;121:1-3.

Margalef R. Limnologia. Barcelona: Ediciones Omega; 1983.

Marie D, Brussaard CPD, Thyrhaug R, Bratbak G, Vaulot D. Enumeration of marine viruses in culture and natural samples by flow cytometry. Appl Environ Microbiol. 1999;65:45-52.

Marin B, Palm A, Klingberg M, Melkonian M. Phylogeny and taxonomic revision of plastid containing Euglenophytes based on SSU rDNA sequence comparisons and synapomorphic signatures in the SSU rDNA secondary structure. Protist. 2003;154:99-145.

Marston MF, Sallee JL. Genetic diversity and temporal variation in the cyanophage community infecting marine Synechococcus species in Rhode Island's coastal waters. Appl Environ Microbiol. 2003;69:4639-4647.

Martínez JM, Schroeder DC, Larsen A, Bratbak G, Wilson WH. Molecular dynamics of Emiliania huxleyi and cooccurring viruses during two separate mesocosm studies. Appl Environ Microbiol. 2007;73:554-562.

Mathias CB, Kirschner AKT, Velimirov B. Seasonal variations of virus abundance and viral control of the bacterial production in a backwater system of the Danube river. Appl Environ Microbiol. 1995;61:3734-3740.

Mehnert DU, Stewien KE. Detection and distribution of rotaviruses in raw sewage and creeks in São Paulo, Brazil. Appl Environ Microbiol. 1993;59:140-143.

Melo S, Rebelo RM, Souza KF, Menezes M, Torgan LC. Fitoplâncton. In: Santos-Silva E, Aprile FM, Scudeller VV, Melo S, organizadores. Bio Tupé: meio físico, diversidade biológica e sociocultural. Manaus:Editora INPA;2005.

Metzeltin D, Lange-Bertalot H. Tropical diatoms of South America. Iconogr Diatomol. 1998;5:1-220.

Miagostovich MP, Ferreira FFM, Guimarães FR, Fumian TM, Diniz-Mendes L, Luz SLB, Silva LA, Leite JPG. Molecular detection and characterization of gastroenteritis viruses occurring naturally in the stream waters of Manaus, Central Amazônia, Brazil. Appl Environ Microbiol. 2008;74:375-382.

Miller ES, Kutter E, Mosig G, Arisaka F, Kunisawa T, Rüger W. Bacteriophage T4 Genome. Microbiol Mol Biol Rev. 2003;67:86-156.

Mitchell JG, Okubo A, Fuhrman JA. Microzones surrounding phytoplankton form the basis for a stratified marine microbial ecosystem. Nature.1985;316:58-59. 
Molecular evolution, phylogenetics and epidemiology. Disponível em $<$ http://tree.bio.ed.ac.uk/software/pathogen/> [2010 Abr 12]

Murray AG, Eldridge PM. Marine viral ecology: Incorporation of bacteriophage into the microbial planktonic food web paradigm. J Plankton Res. 1994;16:627-641.

Murray AE, Hollibaugh JT, Orrego C. Phylogenetic compositions of bacterioplankton from two California estuaries compared by denaturing gradient gel electrophoresis of $16 \mathrm{~s}$ rDNA fragments. Appl Environ Microbiol. 1996;62:2676-2680.

Muyzer G, de Waal EC, Uitterlinden AG. Profiling of complex microbial populations by detaturing gradient gel electrophoresis analysis of polymerase chain reaction amplified genes encoding for $16 \mathrm{~S}$ rDNA. Appl Environ Microbiol. 1993;59:695-700.

Nagasaki K, Tomaru Y, Katanozaka N, Shirai Y, Nishida K, Itakura S, Yamaguchi M. Isolation and characterization of a novel single-stranded RNA virus infecting the bloom-forming diatom Rhizosolenia setigera. Appl Environ Microbiol. 2004;70:704-711.

Nagasaki K, Tomaru Y, Takao Y, Nishida K, Shirai Y, Suzuki H, Nagumo T. Previously unknown virus infects marine diatom. Appl Environ Microbiol. 2005;71:3528-3535.

Noble RT, Fuhrman JA. Virus decay and its causes in coastal waters. Appl Environ Microbiol. 1997;63:77-83.

Noble RT, Fuhrman JA. Use of SYBR Green - I for rapid epifluorescence counts of marine viruses and bacteria. Aquat Microbiol Ecol. 1998;14:133-118.

Noble RT, Fuhrman JA. Rapid virus production and removal as measured with fluorescently labeled viruses as tracers. Appl Environ Microbiol. 2000;66:3790-3797.

Ogino A, Koshikawa H, Nakahara T, Uchiyama H. Succession of microbial communities during a biostimulation process as evaluated by DGGE and clone library analyses. J Appl Microbiol. 2001;91:625-635.

Olson RJ, Chisholm SW, Zettler ER, Altabet MA, Dusenberry, JA. Spatial and temporal distributions of prochlorophyte picoplankton in the North Atlantic Ocean. Deep Sea Res Ser. 1990a;37:1033-1051.

Olson RJ, Chisholm SW, Zettler ER, Armbrust EV. Pigments, size, and distribution of Synechococcus in the North Atlantic and Pacific Oceans. Limnol Oceanogr. 1990b;35:45-58.

Ortmann AC, Suttle CA. High abundances of viruses in a deep-sea hydrothermal vent system indicates viral mediated microbial mortality. Deep-Sea Research I. 2005;52:1515-1527.

Pagel M, Meade A. A phylogenetic mixture model for detecting pattern-heterogeneity in gene sequence or character-state data. Systematic Biology. 2004;53:571-581.

Palmer CM. A composite rating of algae tolerating organic pollution. J Phycol. 1969;5:78-82.

Partensky F, Hess WR, Vaulot D. Prochlorococcus, a marine photosynthetic prokaryote of global significance. Microbiol Mol Biol Rev. 1999;63:106-127.

Patrick R, Reimer, CW. The diatoms of the United States (exclusive of Alaska and Hawaii). Philadelphia: Monographs of Philadelphia Academy of Natural Sciences; 1966. 1 vol.

Patten NL, Seymour JR, Mitchell AG. Flow cytometric analysis of virus-like particles and heterotrophic bacteria within coral-associated reef water. J Mar Biol Assoc UK. 2006;86:563-566.

Patten NL, Mitchell JG, Middelboe M, Eyre BD, Seuront L, Harrison PL, Glud RN. Bacterial and viral dynamics during a mass coral spawning period on the Great Barrier Reef. Aquat Microb Ecol. 2008;50:209-220. 
Paul JH, Jiang SC, Rose JB. Concentration of viruses and dissolved DNA from aquatic environments by Vortex Flow Filtration. Appl Environ Microbiol. 1991;57:2197-2204.

Pedroso DMM, Martins MT. Ultra-morphology of coliphages isolated from water. War Res. 1995;29:1199-1202.

Peduzzi P, Luef B. Viruses, bacteria and suspended particles in a backwater and main channel site of the Danube (Austria). Aquatic Sciences. 2008;70:186-194.

Peragallo M, Peragallo M. Diatome'es marines de France et des districts maritimes voisins. Re'impression. Amsterdam: A. Asher \& Co.; 1965. 491 p.

Pomeroy R, Kirschman HD. Determination of dissolved oxygen. Proposed modification of the Winkler method. Ind Eng Chem Res. 1945;17:715-716.

Proctor LM, Fuhrman JA, Ledbetter MC. Marine bacteriophages and bacterial mortality. Eos. 1988;69:1111-1112.

Proctor LM, Fuhrman JA. Viral mortality of marine bacteria and cyanobacteria. Nature. 1990;343:6062.

Proctor LM, Fuhrman JA. Roles of viral infection in organic particle flux. Mar Ecol Prog Ser. 1991;69:133-142.

Queiroz APS, Santos FM, Sassaroli A, Hársi CM, Monezi TA, Mehnert DU. Electropositive filter membrane as an alternative for the elimination of PCR inhibitors from sewage and water samples. Appl Environ Microbiol. 2001;67:4614-4618.

Ram ASP, Sime-Ngando T. Functional responses of prokaryotes and viruses to grazer effects and nutrient additions in freshwater microcosms. ISME Journal. 2008;2:498-509.

Rambaut A. Se-Al: Sequence Alignment Editor. 1996. Disponível em <http://evolve.zoo.ox.ac.uk/> [2010 Fev 10].

Raupp SV, Torgan L, Melo S. Planktonic diatom composition and abundance in the Amazonian floodplain Cutiuaú Lake are driven by the flood pulse. Acta Limnol Bras. 2009;21:227-234.

Rejas D, Muylaert K, De Meester L. Nutrient limitation of bacteria and sources of nutrients supporting nutrient-limited bacterial growth in an Amazonian floodplain lake. Aquat Microb Ecol. 2005;39:57-67.

Renne PR, Zhang Z, Richardson MA, Black MT, Basu AR. Synchrony and causal relations between Permian-Triassic boundary crisis and Siberian flood volcanism. Science. 1995;269:1413-1416.

Rio D, Sprovieri R, Castradori D, Di Stefano E. The Gelasian Stage (Upper Pliocene): A new unit of the global standard chronostratigraphic scale. Episodes. 1998;21:82-87.

Ripp S, Ogunseitan OA, Miller RV. Transduction of a freshwater microbial community by a new Pseudomonas aeruginosa generalized transducing phage, UTL. Mol Ecol. 1994;3:121-126.

Roelfsema JH, Peters DJM. Denaturing Gradient Gel Electrophoresis (DGGE). In: Walker JM, Rapley R, editors. Medical Biomethods Handbook. Totowa, New Jersey; Humana Press. 2005; p. 7986.

Romano CM, Zanotto PM, Holmes EC. Bayesian coalescent analysis reveals a high rate of molecular evolution in GB vírus C. J Mol Evol. 2008;66:292-97.

Romano CM. Caracterização e dinâmica evolutiva de retrovírus endógenos da família K (ERV-K) em genomas de primatas [tese (Doutorado em Microbiologia)]. São Paulo: Instituto de Ciências Biomédicas da Universidade de São Paulo; 2009. 
Rosero EMB. Frequência e diversidade de colifagos somáticos isolados de amostras de água do mar, plâncton e bivalves da Baixada Santista, Canal de São Sebastião e Ubatuba [tese (Doutorado em Microbiologia)]. São Paulo: Instituto de Ciências Biomédicas da Universidade de São Paulo; 2009.

Rusch DB, Halpern AL, Sutton G, Heidelberg KB, Williamson S, Yooseph S, et al. The Sorcerer II Global Ocean Sampling expedition: northwest Atlantic through eastern tropical Pacific. PLoS Biol. 2007;5:398-431.

Sabine CL, Feely RA, Gruber N, Key RM, Lee K, Bullister JL, et al. The ocean sink for anthropogenic $\mathrm{CO}_{2}$. Science. 2004;305:367-371.

Sant'Anna CL, Azevedo MTP, Branco LZ, Braga MRA, Cordeiro-Marino M, Guimarães SMPB. Cianofíceas marinhas bentônicas das Praias de Peruíbe e dos Sonhos, Município de Itanhaém, SP. III. Rev. Brasil. Biol. 1995;55:389-407.

Sant'Anna CL. Chlorococcales (Chlorophyceae) do estado de São Paulo, Brasil. Bibliotheca Phycologica. 1984;67:1-348.

Sant'Anna CL. Scytonemataceae (Cyanophyceae) from the State of São Paulo, southern Brazil. Nova Hedwigia. 1988;46:519-539.

Santos U, Ribeiro MNG. A hidroquímica do rio Solimões - Amazonas. Acta Amaz. 1988;18:145-172.

Santos FM, Vieira MJ, Monezi TA, Hársi CM, Mehnert DU. Discrimination of adenovirus types circulating in urban sewage and surface polluted waters in São Paulo city, Brazil. Water Sci Tech. 2004:4:79-85.

Säwström C, Anesio MA, Graneli W, Laybourn-Parry J. Seasonal viral loop dynamics in two large ultraoligotrophic Antarctic freshwater lakes. Microb Ecol. 2007;53:1-11.

Schroeder DC, Oke J, Hall MJ, Evans C, Malin G, Wilson WH. Virus genotypic succession observed during an Emiliania huxley bloom. Appl Environ Microbiol. 2003;69:2484-2490.

Shapiro B, Rambaut A, Drummond AJ. Choosing appropriate substitution models for the phylogenetic analysis of protein-coding sequences. Mol Biol Evol. 2006;23:7-9.

Shirai Y, Tomaru Y, Takao Y, Suzuki H, Nagumo T, Nagasaki K. Isolation and characterization of a single-stranded RNA virus infecting the marine planktonic diatom Chaetoceros tenuissimus Meunier. Appl Environ Microbiol. 2008;74:4022-4027.

Short SM, Suttle CA. Use of the polymerase chain reaction and denaturing gradient gel electrophoresis to study diversity in natural virus communities. Hydrobiologia. 1999;401:19-32.

Short SM, Suttle CA. Denaturing gradient gel electrophoresis resolves virus sequences amplified with degenerate primers. Biotechniques. 2000;28:20-26.

Short SM, Suttle CA. Sequence analysis of marine virus communities reveals that groups of related algal viruses are widely distributed in nature. Appl Environ Microbiol. 2002;68:1290-1296.

Short SM, Suttle CA. Temporal dynamics of natural communities of marine algal viruses and eukaryotes. Aquat Microb Ecol. 2003;32:107-119.

Short CM, Suttle CA. Nearly identical bacteriophage structural gene sequences are widely distributed in both marine and freshwater environments. Appl Environ Microbiol. 2005;71:480-486.

Short SM, Short CM. Diversity of algal viruses in various North American freshwater environments. Aquat Microb Ecol. 2008;51:13-21. 
Sieburth JM, Johnson PW, Hargraves PE. Ultrastructure and ecology of Aureococcus anophagefferens gen. et sp. nov. (Chrysophyceae) the dominant picoplankter during a bloom in Narragansett Bay Rhode Island USA summer 1985. J. Phycol. 1988;24:416-425.

Sigee DC. Freshwater Microbiology: biodiversity and dynamic interactions of microorganisms in the freshwater environment. Chichester: John Wiley \& Sons; 2005.

Sinauer Associates Inc. Disponivel em <http://www.sinauer.com/hall/2e/> [2010 Mar 11]

Sioli H. Tropical River as Expressions of their Terrestrial Environments. In: Golley FB, Medina E. editors. Tropical Ecological Systems Trends in Terrestrial and Aquatic Reserarch. Berlin: SpringerVerlag; 1975a; p. 289-312.

Sioli H. Tropical River: The Amazon. In: Whitton BA. River Ecology. Berkeley: UC Press; 1975b; p. 461-487.

Smayda TJ. Ecophysiology and bloom dynamics of Heterosigma akashiwo (Raphidophyceae). In: Anderson DM, Cembella AD, Hallegraeff GM, editors. Physiological Ecology of Harmful Algal Blooms. Berlin:Springer-Verlag; 1998. p. 113-131.

Smurov AO, Fokin SI. Use of salinity tolerance data for investigation of phylogeny of Paramecium (Ciliophora, Peniculia). Protistology. 2001;2:130-138.

Souza-Mosimann RM, Tavares AS, Freitas VP. Contribuição ao conhecimento da diatomoflórula amazônica. I-Myleus SP. (Pacu) do Lago do Prato, AM, Brasil. Acta Amaz. 1997;27:9-25.

Spanakis E, Horne MT. Co-adaptation of Escherichia coli and coliphage lambda virus in continuous culture. J Gen Microbiol. 1987;133:353-360.

Steinberg CEW. Ecology of Humic Substances in Freshwaters. New York: Springer-Verlag; 2003.

Steward GF, Wikner J, Cochlan WP, Smith DC, Azam F. Estimation of virus production in the sea: 2 Field results. Mar Microb Food Webs. 1992;6:79-90.

Steward GF, Smith DC, Azam F. Abundance and production of bacteria and viruses in the Bering and Chukchi Seas. Mar Ecol Prog Ser. 1996;131:287-300.

Suchard MA, Weiss RE, Sinsheimer JS. Bayesian selection of continuous-time Markov chain evolutionary models. Mol Biol Evol. 2001;18:1001-1013.

Sullivan MB, Waterbury JB, Chisholm SW. Cyanophages infecting the oceanic cyanobacterium Prochlorococcus. Nature. 2003;424:1047-1051.

Sullivan MB, Lindell D, Lee JA, Thompson LR, Bielawski JP, Chisholm SW. Prevalence and evolution of core photosystem II genes in marine cyanobacterial viruses and their hosts. PLoS Biol. 2006;4: e234.

Suttle CA, Chan AM, Cottrell MT. Use of ultrafiltration to isolate viruses from seawater which are pathogens of marine phytoplankton. Appl Environ Microbiol. 1991;57:721-726.

Suttle CA, Chen F. Mechanisms and rates of decay of marine viruses in seawater. Appl Environ Microbiol. 1992;58:3721-3729.

Suttle CA, Chan AM. Marine cyanophages infecting oceanic and coastal strains of Synechococcus: abundance, morphology, cross-infectivity and growth characteristics. Mar Ecol Prog Ser. 1993;92:99109.

Suttle CA. Enumeration and isolation of viruses. In: Kemp PF, editor. Handbook of methods in aquatic microbial ecology. Boca Raton: CRC Press; 1993. p. 121-134. 
Suttle CA, Chan AM. Dynamics and distribution of cyanophages and their effects on marine Synechococcus spp. Appl Environ Microbiol. 1994;60:3167-3174.

Suttle CA, Chan AM. Viruses infecting the marine Prymnesiophyte Chrysochromulina spp.: isolation, preliminary characterization and natural abundance. Mar Ecol Prog Ser. 1995;118:275-282.

Suttle CA. Cyanophages and their role in the ecology of cyanobacteria. In: Whitton BA, Potts M, editors. The Ecology of Cyanobacteria: Their Diversity in Tiime and Space. Boston: Kluwer Academic Publishers; 2000. p. 563-589.

Suttle CA. Viruses in the sea. Nature. 2005;437:356-361.

Suttle CA. Marine viruses-major players in the global ecosystem. Nature Reviews Microbiology. 2007;5:801-812.

Tell G, Conforti VTD. Euglenophyta pigmentadas de la Provincia del Chaco (Argentina). Nova Hedwigia. 1986;41:353-391.

The Universal Virus Database of the International Committee on Taxonomy of Viruses. Disponível em $<$ http://www.ictvdb.org> [2010 Jul 15]

Thingstad TF, Lignell, R. Theoretical models for the control of bacterial growth rate, abundance, diversity and carbon demand. Aquat Microb Ecol. 1997;13:19-27.

Thingstad TF. Elements of a theory for the mechanisms controlling abundance, diversity, and biogeochemical role of lytic bacterial viruses in aquatic systems. Limnol Oceanogr. 2000;45:13201328.

Thompson JN. Rapid evolution as an ecological process. Trends Ecol Evol. 1998;13:329-332.

Thorne JL, Kishino H, Painter IS. Estimating the rate of evolution of the rate of molecular evolution. Mol Biol Evol. 1998;15:1647-57.

Tijdens M, Van de Waal DB, Slovackova H, Hoogveld HL, Gons HJ. Estimates of bacterial and phytoplankton mortality caused by viral lysis and microzooplankton grazing in a shallow eutrophic lake. Freshwater Biol. 2008a;53:1126-1141.

Tijdens M, Hoogveld HL, Agterveld MPK, Simis SGH, Baudoux A-C, Laanbroek HJ, Gons HJ. Population dynamics and diversity of viruses, bacteria and phytoplankton in a shallow eutrophic lake. Microb Ecol. 2008b;56:29-42.

Tomaru Y, Takao Y, Suzuki H, Nagumo T, Nagasaki K. Isolation and characterization of a singlestranded RNA virus infecting the bloom-forming diatom Chaetoceros socialis. Appl Environ Microbiol. 2009;75:2375-2381.

Torrella F, Morita RY. Evidence by electron micrographs for a high incidence of bacteriophage particles in the waters of Yaquina Bay, Oregon: ecological and taxonomical implications. Appl Environ Microbiol. 1979;37:774-778.

Uherkovich G, Schimidt GW. Phytoplanktontaxa in dem zentralamazonischen Schwemmlandsee. Amazoniana. 1974;5;243-283.

Uherkovich G. Algen aus den Flüssen Rio Negro und Rio Tapajós. Amazoniana. 1976;5:465-515.

Uherkovich G, Rai H. Algen aus dem Rio Negro und seinen Nebenflüssen. Amazoniana. 1979;6:611638.

Van Hannen EJ, Zwart G, Van Agterveld MP, Gons HJ, Ebert J, Laanbroek HJ. Changes in bacterial and eukaryotic eukaryotic community structure after mass lysis of filamentous cyanobacteria associated with viruses. Appl Environ Microbiol. 1999;65:795-801. 
Vanucci S, Bruni V, Pulicano G. Spatial and temporal distribution of virioplankton and bacterioplankton in a brackish environment (Lake of Ganzirri, Italy). Hydrobiologia. 2005;539:83-92.

Van Etten JL, Graves MV, Müller DG, Boland W, Delaroque N. Phycodnaviridae - large DNA viruses. Arch Virol. 2002;147:1479-1516.

Wang G, Hayashi M, Saito M, Tsuchiya K, Asakawa S, Kimura M. Survey of major capsid genes ( $g 23$ ) of T4-type bacteriophages in Japanese paddy field soils. Soil Biol Biochem. 2009a;41:13-20.

Wang G, Jin J, Asakawa S, Kimura M. Survey of major capsid genes (g23) of T4-type bacteriophages in rice fields in Northeast China. Soil Biol Biochem. 2009b;41:423-427.

Waterbury JB, Watson SW, Valois FW, Franks DG. Biological and ecological characterization of the marine unicellular cyanobacterium Synechococcus. Can Bull Fish Aquat Sci. 1986;214:71-120.

Waterbury JB, Valois FW. Resistance to cooccurring phages enables marine Synechococcus communities to coexist with cyanophages abundant in seawater. Appl Environ Microbiol. 1993;59:3393-3399.

Weinbauer MG, Fuks D, Puskaric S, Peduzzi P. Diel, seasonal, and depth-related variability of viruses and dissolved DNA in the Northern Adriatic sea. Microb Ecol. 1995;30:25-41.

Weinbauer MG, Suttle CA. Comparison of epifluorescence and transmission electron microscopy for counting viruses in natural marine waters. Aquat Microb Ecol. 1997;13:225-232.

Weinbauer MG, Wilhelm SW, Suttle CA, Garza DR. Photoreactivation compensates for UV damage and restores infectivity to natural marine virus communities. Appl Environ Microbiol. 1997;63:22002205.

Weinbauer MG. Ecology of prokaryotic viruses. FEMS Microb Rev. 2004;28:127-181.

Wetzel RG. Limnology: Lake and River Ecosystems. San Diego, California: Academic Press; 2001.

Wichels A, Biel SS, Gelderblom RH, Brinkhoff T, Muyzer G, Schütt C. Bacteriophage diversity in the North Sea. Appl Environ Microbiol. 1998;64:4128-4133.

Wikipédia: a enciclopédia livre. Disponível em <http://pt.wikipedia.org> [2010 Jul 10]

Wilhelm SW, Weinbauer MG, Suttle CA, Jeffrey WH. The role of sunlight in the removal and repair of viruses in the sea. Limnol Oceanogr. 1998a;43:586-592.

Wilhelm SW, Weinbauer MG, Suttle CA, Pledger RJ, Mitchell DL. Measurements of DNA damage and photoreactivation imply that most viruses in marine surface waters are infective. Aquat Microb Ecol. 1998b;14:215-222.

Wilhelm SW, Suttle CA. Viruses and nutrient cycles in the sea. Bioscience. 1999;49:781-788.

Wilhelm SW, Brigden SM, Suttle CA. A dilution technique for the direct measurement of viral production: a comparison in stratified and tidally mixed coastal waters. Microb Ecol. 2002;43:168-173.

Wilhelm SW, Jeffrey WH, Dean AL, Meador J, Pakulski JD, Mitchell DL. UV radiation induced DNA damage in marine viruses along a latitudinal gradient in the southeastern Pacific Ocean. Aquat Microb Ecol. 2003;31:1-8.

Wilhelm SW, Matteson AR. Freshwater and marine virioplankton: a brief overview of commonalities and differences. Freshwater Biol. 2008;53:1076-1089.

Wilson WH, Fuller NJ, Joint IR, Mann NH. Analysis of cyanophage diversity in the marine environment using denaturing gradient gel electrophoresis. In: Bell CR, Brylinsky M, Johnson-Green P, editors. Proc 8th Int Symp Microb Ecol. Atlantic Canada Society for Microbial Ecology. Halifax; 2000. 
Wilson WH, Schroeder DC, Ho J, Canty M. Phylogenetic analysis of PgV-102P, a new virus from the English Channel that infects Phaeocystis globosa. J Mar Biol Ass U.K. 2006;86:485-490.

Wilson WH, Van Etten JL, Allen MJ.The Phycodnaviridae: the story of how tiny giants rule the world. Curr Top Microbiol. 2009; 328:1-42.

Winget DM, Wommack KE. Randomly amplified polymorphic DNA PCR as a tool for assessment of marine viral richness. Appl Environ Microbiol. 2008;74:2612-2618.

Winkler L. Die bestimmung des in wasser gelösten sauerstoffes. Berichte der Deutschen Chemischen Gesellschaft. 1888;21:2843-2855.

Wommack KE, Hill RT, Kessel M, Russek-Cohen E, Colwell RR. Distribution of viruses in the Chesapeake Bay. Appl Environ Microbiol. 1992;58:2965-2970.

Wommack KE, Hill RT, Colwell RR. A simple method for the concentration of viruses from natural water samples. J Microbiol Methods. 1995;22:57-67.

Wommack KE, Hill RT, Muller TA, Colwell RR. Effects of sunlight on bacteriophage viability and structure. Appl Environ Microbiol. 1996;62:1336-1341.

Wommack KE, Ravel J, Hill RT, Colwell RR. Hybridization analysis of chesapeake bay virioplankton. Appl Environ Microbiol. 1999a;65:241-250.

Wommack KE, Ravel J, Hill RT, Chun J, Colwell RR. Population dynamics of chesapeake bay virioplankton: total-community analysis by pulsed-field gel electrophoresis. Appl Environ Microbiol. 1999b;65:231-240.

Wommack KE, Colwell RR. Virioplankton: viruses in aquatic ecosystems. Microbiol Molec Biol Rev. 2000;64:69-114.

Zanotto PMA, Gould EA, Gao GF, Harvey PH, Holmes EC. Population dynamics of flaviviruses revealed by molecular phylogenies. Proc Natl Acad Sci. 1996;93:548-553.

Zhang YP, Suttle CA. Design and use of PCR primers for B-family DNA polymerase genes to detect and identify viruses and microbes. In: ASLO \& PSA Joint Meeting; 1994; Lawrence, Kans: American Society for Limnology and Oceanography; 1994. p.a-85.

Zhang Y, Jiao N. Roseophage RDJL Phi1, infecting the aerobic anoxygenic phototrophic bacterium Roseobacter denitrificans OCh114. Appl Environ Microbiol. 2009;75:1745-1749.

Zhong Y, Chen F, Wilhelm SW, Poorvin L, Hodson RE. Phylogenetic diversity of marine cyanophage isolates and natural virus communities as revealed by sequences of viral capsid assembly protein gene g20. Appl Environ Microbiol. 2002;68:1576-1584.

Zillig W, Prangishvilli D, Schleper C, Elferink M, Holz I, Albers S, Janekovic D, Gotz D. Viruses, plasmids and other genetic elements of thermophilic and hyperthermophilic Archaea. FEMS Microb Rev. 1996;18:225-236. 
ANEXOS 


\section{ANEXO A}

Mapa parcial do genoma do vírus $P B C V$-1, com indicação dos genes transcritos da direita para a esquerda e $(L, \leftarrow)$ e da esquerda para a direita $(R, \rightarrow)$. Genes com funções semelhantes ou relacionadas estão identificados pela mesma cor. Gene DNA pol indicado pela seta $(\rightarrow)$.

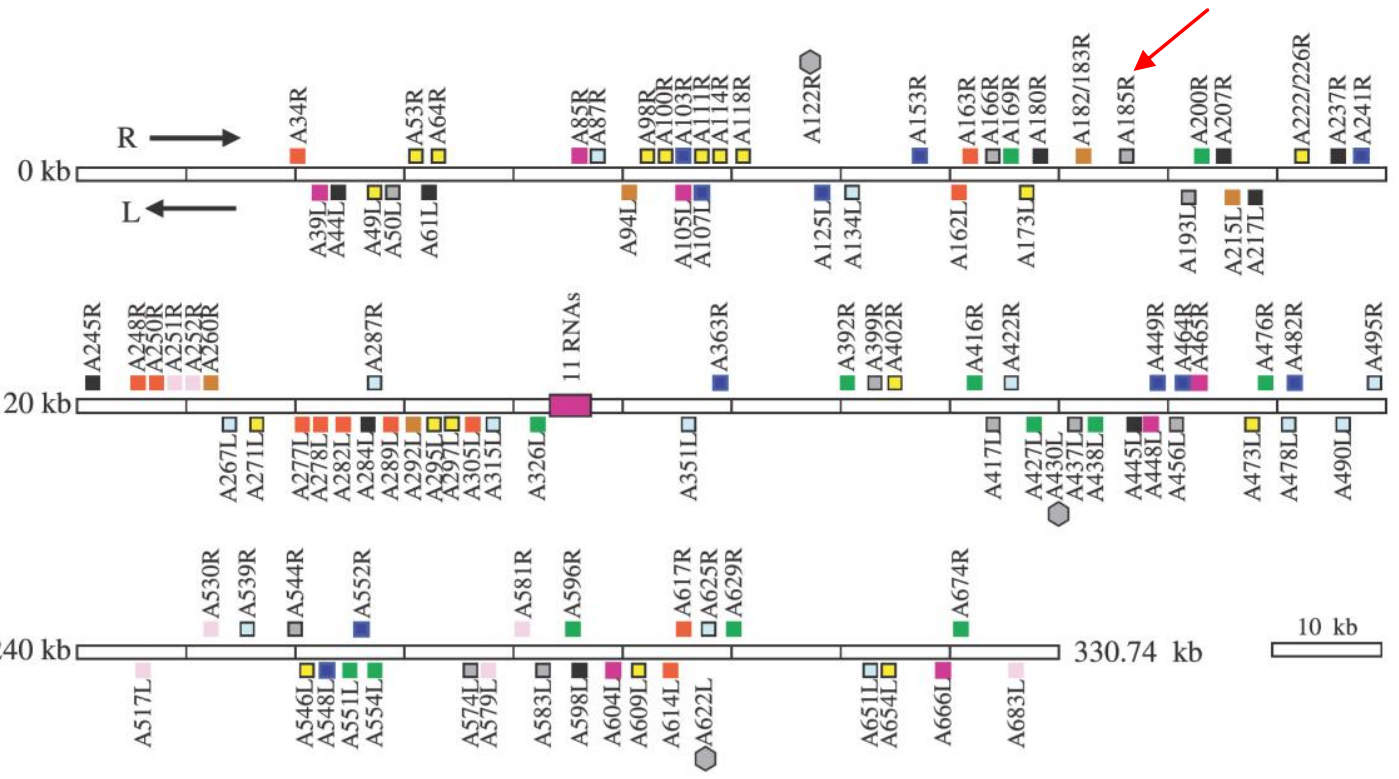

$\square$ MetabolismDNA Replication, Recombination, and Repair

\begin{tabular}{|c|c|c|}
\hline & & \\
\hline & A185R & $\delta$ DNA polymerase \\
\hline $\begin{array}{l}\text { (E) } \\
\text { (E) }\end{array}$ & A544R* & $\begin{array}{l}\text { ATP-dependent DNA ligase } \\
\text { DNA topoisomerase II }\end{array}$ \\
\hline \multirow[t]{4}{*}{ (E) } & A583L* & DNA topoisomerase II \\
\hline & A193L & PCNA \\
\hline & A574L & PCNA \\
\hline & A399R & RNaseH \\
\hline & $\mathrm{A} 456 \mathrm{~L}$ & Superfamily III helicase \\
\hline \multicolumn{2}{|c|}{$\begin{array}{l}\mathrm{A} 450 \mathrm{~L} \\
(\mathrm{E}, \mathrm{L}) \mathrm{A} 50 \mathrm{~L}^{*}\end{array}$} & Pyrimidine dimer-specific glycosyla \\
\hline \multicolumn{2}{|c|}{$\mathrm{A} 437 \mathrm{~L}$} & DNA binding protein \\
\hline & $\mathrm{A} 417 \mathrm{~L}$ & Replication factor $\mathrm{C}$ \\
\hline & A166R* & Exonuclease \\
\hline & \multicolumn{2}{|c|}{ Nucleotide Metablism } \\
\hline \multirow[t]{5}{*}{ (E) } & $\mathrm{A} 169 \mathrm{R}^{*}$ & Aspartate transcarbamylase \\
\hline & A476R & Ribo. reductase (small subunit) \\
\hline & A629R & Ribo. reductase (large subunit) \\
\hline & A427L & Thioredoxin \\
\hline & A438L* & Glutaredoxin \\
\hline & A551L* & dUTP pyrophosphatase \\
\hline & A596R* ${ }^{*}$ & dCMP deaminase \\
\hline & A416R & $\mathrm{dG} / \mathrm{dA}$ kinase \\
\hline & A $326 \mathrm{~L}$ & NTP pyrophosphohydrolase \\
\hline & A200R & Cytidine deaminase \\
\hline & A674R* & Thymidylate synthase $\mathrm{X}$ \\
\hline & A554L & ATPase \\
\hline (E) & A392R & ATPase \\
\hline \multicolumn{3}{|c|}{ Transcription } \\
\hline \multirow{8}{*}{$\begin{array}{l}\text { (E) } \\
\text { (E) } \\
\text { (E) }\end{array}$} & A107L & Transcription factor TFIIB \\
\hline & A125L & Transcription factor TFIIS \\
\hline & A552R & Transcription factor TFIID \\
\hline & A482R & VLTF2-type transcription factor \\
\hline & $\mathrm{A} 103 \mathrm{R}^{*}$ & RNA guanylyltransferase \\
\hline & A449R* & RNA triphosphatase \\
\hline & A153R & Superfamily II helicase \\
\hline & A363R & Superfamily II helicase \\
\hline \multirow{3}{*}{ (E) } & A464R* & RNase II \\
\hline & A548L & SWI/SNF helicase \\
\hline & A241R & Skil helicase \\
\hline & A612L* & Histone $\mathrm{H} 3$, Lys27 methylase \\
\hline & \multicolumn{2}{|c|}{$\begin{array}{l}\text { Protein Synthesis, Modification, } \\
\text { and Degradation }\end{array}$} \\
\hline & \multirow{2}{*}{$\begin{array}{c}\text { A39L } \\
\text { E,L) } \mathrm{A} 666 \mathrm{~L}\end{array}$} & SKP-1 protein \\
\hline & & Translation elongation factor- 3 \\
\hline & A85R* & Prolyl 4-hydroxylase \\
\hline & A105L & Ubiquitin C-terminal hydrolase \\
\hline & A448L & Protein disulphide isomerase \\
\hline & A465R & Thiol oxidoreductase \\
\hline & $\mathrm{A} 604 \mathrm{~L}$ & $\mathrm{Zn}$ metallopeptidase \\
\hline & & 11 tRNAs \\
\hline
\end{tabular}

Cell Wall Degrading Enzymes

$\begin{array}{lll}\text { (E) A94L* } & \beta \text {-1,3-glucanase } \\ \text { (E) A181/182R* } & \text { Chitinase } \\ \text { (L) A260R* } & \text { Chitinas } \\ \text { (L) A292 } & \text { Chitosanase } \\ \text { (E,L) A215L* } & \text { Alginate lyase }\end{array}$

$\square$ Sugar and Lipid Manipulation

(E) A98R* $\quad$ Hyaluronan synthase

$\begin{array}{ll}\text { (E) } \mathrm{AlO0R}^{*} & \text { Glucosamine synthase } \\ \text { (E) } \mathrm{A} 609 \mathrm{~L}^{*} & \text { UDP-glucose dehydrogenas }\end{array}$

(E) Al18R* GDP-D-mannose dehydratas

(E) A295L* Fucose synthase

(E,L) A64R Mannosyltransferase

A111R Glycosyltransferase

A114R Fucosyltransferase

A222/226R Glycosyltransferase

E) A473L Glycosyltransferase

A546L Glycosyltransferase

A53R 2-hydroxyacid dehydrogenase

A173L $\quad$ Patatin phospholipase

A173L Patatin phospholipase

A297L Fructose-2,6-bisphosphatase

A402R Lipoprotein lipase

A654L N-acetyltransferase

Signaling

(E,L) A250R*

$\mathrm{K}^{*}$ channel protein

A163R Ligand-gated channel protein

A34R* Ser/Thr protein kinase

(L) A248R* Ser/Thr Protein kinase

A277L Ser/Thr protein kinase

A278L* $\quad$ Ser/Thr protein kinase

A282L* $\quad$ Ser/Thr protein kinase

A289L* $\quad$ Ser/Thr protein kinase

A305L Tyr phosphatase

A614L* $\quad$ Protein Kinase

A617R Tyr-protein kinase

$\square$ DNA Restriction/Modification

A251R* Adenine DNA methylase [M. CviAII]

DNA restriction endonuclease [R. CviA]

(E) $\mathrm{A}^{2} 17 \mathrm{~L}^{*}$ Cytosine DNA methylase [M. CviAIII]

(L) A530R Cytosine DNA methylase [M. CviAIV]

(E) A581R * Adenine DNA molhlase [M. CviAI]

$\begin{array}{ll}\text { A579L* } & \text { DNA restriction endonuclease [R. CviAI] } \\ \text { A683L } & \text { Cytosine DNA methyltransferase [M.CviAV](E,L) }\end{array}$ $\square$ Integration and Transposition

$\begin{array}{ll}\text { A625R } & \text { Transposase } \\ \text { A134L } & \text { Homing endonuclease GIY-YIG } \\ \text { A287R } & \text { Homing endonuclease GIYYYIG } \\ \text { A315L } & \text { Homing endonuclease GIYYYIG } \\ \text { A351L } & \text { Homing endonuclease GYYYIG } \\ \text { A495R } & \text { Homing endonuclease GIYYIG } \\ \text { A539R } & \text { Homing endonuclease GIYYIG } \\ \text { A651L } & \text { Homing endonuclease GYYYIG } \\ \text { A422R } & \text { Homing endonuclease HNH } \\ \text { A87R } & \text { Homing endonuclease HNH } \\ \text { A267L } & \text { Homing endonuclease HNH } \\ \text { A478L } & \text { Homing endonuclease HNH } \\ \text { A490L } & \text { Homing endonuclease HNH(L) }\end{array}$

Miscellaneous

(E,L) A207R* Ornithine decarboxylase

(L) A237R* Homospermidine synthase

(E) A78R* N-carbamoylput amidohydrolase

(E) A638R* Agmatine iminohydrolase

A217L Monoamine oxidase

A44L BCS1 protein

A6IL O-methyltransferase

A180R Fibronectin binding protein

A245R* $\quad \mathrm{Cu} / \mathrm{Zn}$-superoxide dismutas

A284L* Amidase

$\mathrm{A} 445 \mathrm{~L} \quad \mathrm{ABC}$ transporter protein

A598L Histidine decarboxylase

Structural Proteins

$\begin{array}{lll}\text { (L) A430L } & \text { Vp54, major coat protein } \\ \text { (L) A622L } & \text { Coat protein-like }\end{array}$

$\begin{array}{ll}\text { A622L } & \text { Coat protein-like } \\ \text { A122R } & \text { Glycoprotein Vp260 }\end{array}$

* Functional enzyme

(E) Early gene

(L) Late gene

Fonte: Kang et al.(2005). 


\section{ANEXO B}

Mapa funcional do genoma do fago T4 com marcação do gene gp23 ( $\square$ ).
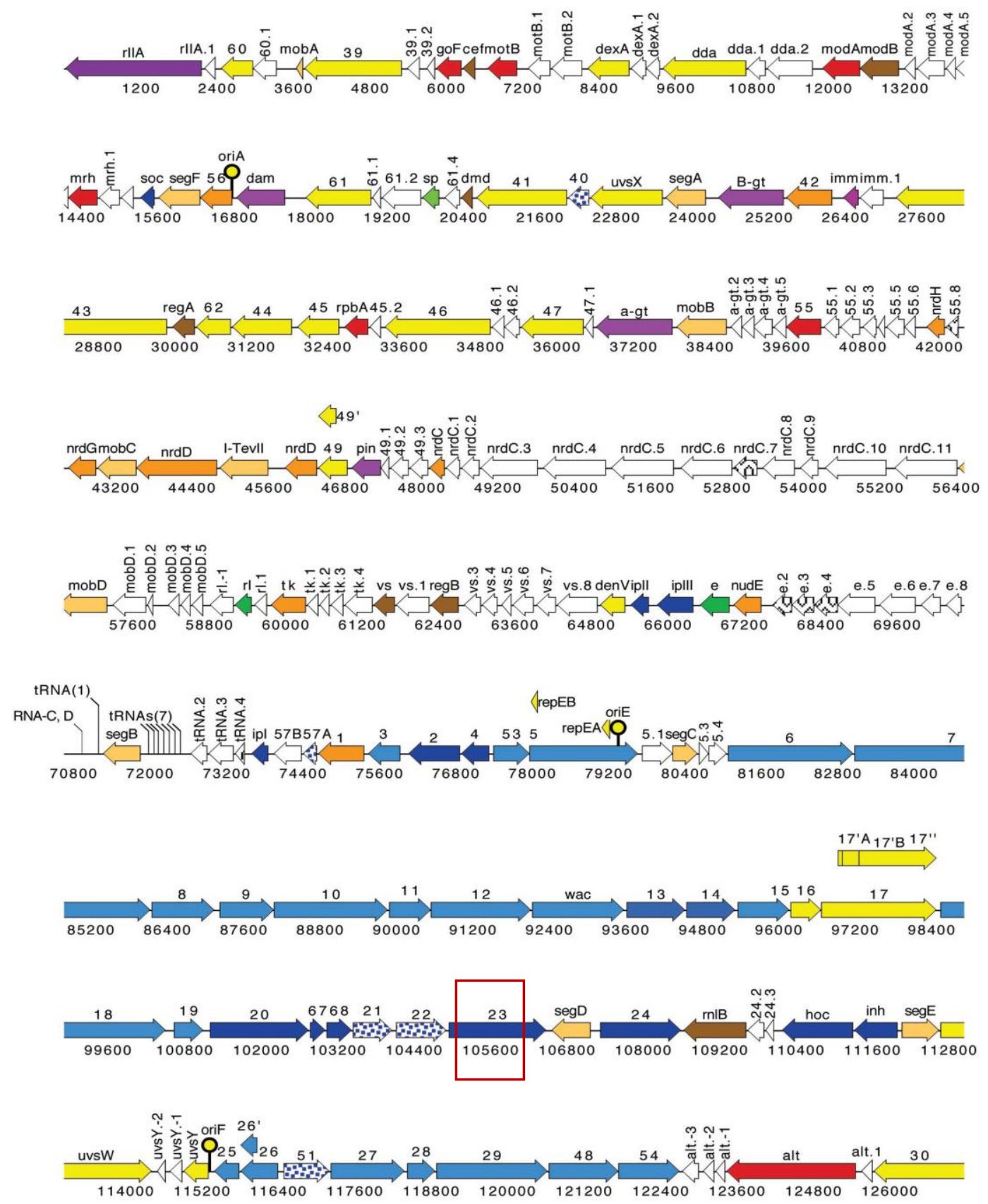

$\left\langle 30.3^{\prime}\right.$

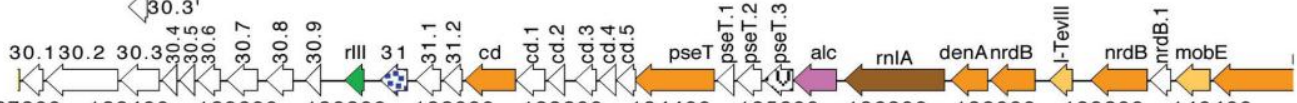

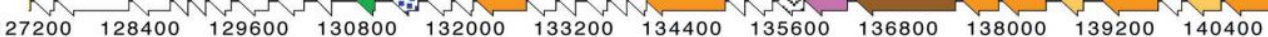

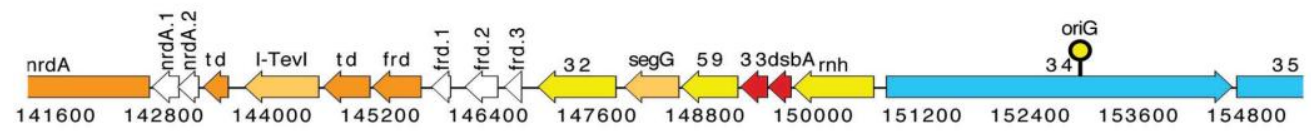
Transcription
Translation
Nucleotide metabolism
$\square$ DNA replication,
recombination, repair,
packaging, and processing
Virion proteins - head
$\square$ Virion proteins - neck
$\square$ Virion proteins - tail
$\square$ Virion proteins - tail fiber
$\square$ Chaperonins/assembly
$\square$ Lysis
$\square$ Host or phage interactions
$\square$ Host alteration/shutoff
$\square$ Homing endonucleases and homologs
$\square$ Unknown

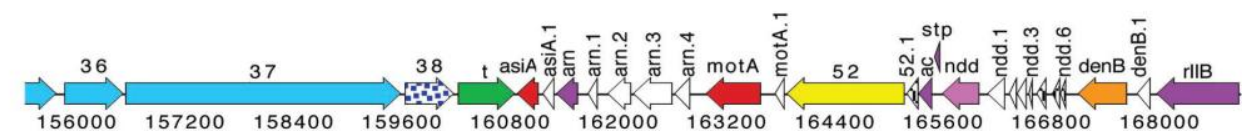

Fonte: Miller et al.(2003). 


\section{ANEXO C}

Sequências de clones ambientais usadas na reconstrução filogenética dos ficodnavírus.

\begin{tabular}{|c|c|c|c|}
\hline $\begin{array}{c}N^{\circ} \text { acesso do } \\
\text { GenBank }\end{array}$ & Origem & Ambiente & Data \\
\hline $\begin{array}{c}\text { AF405572 ao } \\
\text { AF405576 }\end{array}$ & SO & SW & 1998 \\
\hline $\begin{array}{c}\text { AF405577 ao } \\
\text { AF405598 }\end{array}$ & $\mathrm{CA}$ & SW & 1999 \\
\hline $\begin{array}{c}\text { AY345136 ao } \\
\text { AY345142 }\end{array}$ & NS & SW & 2000 \\
\hline $\begin{array}{c}\text { AY145089 ao } \\
\text { AY145098 }\end{array}$ & $\mathrm{CA}$ & SW & 2001 \\
\hline $\begin{array}{c}\text { EU408225 ao } \\
\text { EU408244 }\end{array}$ & $\mathrm{CA}$ & LK & 2004 \\
\hline $\begin{array}{c}\text { EU336477 ao } \\
\text { EU336571 }\end{array}$ & US & LK & 2005 \\
\hline $\begin{array}{c}\text { EU336708 ao } \\
\text { EU336803 }\end{array}$ & US & $\mathrm{RV}$ & 2005 \\
\hline $\begin{array}{c}\text { EU889358 aо } \\
\text { EU889373 }\end{array}$ & $\mathrm{HW}$ & SW & 2006 \\
\hline $\begin{array}{c}\text { EU336433 ao } \\
\text { EU336476 }\end{array}$ & $\mathrm{CA}$ & LK & 2007 \\
\hline $\begin{array}{c}\text { EU336573 ao } \\
\text { EU336707 }\end{array}$ & $\mathrm{CA}$ & LK & 2007 \\
\hline $\begin{array}{c}\text { AY436587 ao } \\
\text { AY436589 }\end{array}$ & SK & MA & n.d. \\
\hline
\end{tabular}

Origem: US - Estados Unidos; CA - Canadá; NS Mar do Norte; HW - Havaí; SK - Coréia do Sul. Ambiente: RV - rio; SW - mar; LK - lago; MA aerossol marinho. Para a análise de movimentação de ficodnavírus entre ambientes aquáticos, SW e MA foram considerados "mar".

n.d.: não disponível. 


\section{ANEXO D}

Isolados da família Phycodnaviridae usados na reconstrução filogenética dos ficodnavírus.

\begin{tabular}{|c|c|c|c|c|c|}
\hline Gênero & Espécie & Origem & Ambiente & Data & $\begin{array}{c}\mathbf{N}^{\circ} \text { acesso do } \\
\text { GenBank }\end{array}$ \\
\hline \multirow[t]{38}{*}{ Chlorovirus } & PBCV1 AL-1A & US & PO & 1984 & AF344198 \\
\hline & PBCV1 AL-2A & US & PO & 1984 & AF344199 \\
\hline & PBCV1 AL-2C & US & PO & 1984 & AF344200 \\
\hline & PBCV1 AN-69C & $A U$ & FW & 1995 & AF344201 \\
\hline & PBCV1 AR158 & $A R$ & $\mathrm{FW}$ & 1997 & AF344202 \\
\hline & PBCV1 AR93.2 & AR & FW & 1997 & AF344203 \\
\hline & PBCV1 BJ-2C & $\mathrm{CH}$ & PO & 1987 & AF344204 \\
\hline & $P B C V 1 C A-1 A$ & US & ST & 1984 & AF344205 \\
\hline & PBCV1 CA-1D & US & ST & 1984 & AF344206 \\
\hline & $P B C V 1 C A-2 A$ & US & ST & 1984 & AF344207 \\
\hline & $P B C V 1 C A-4 A$ & US & $\mathrm{DD}$ & 1984 & AF344208 \\
\hline & $P B C V 1 C A-4 B$ & US & DD & 1984 & AF344209 \\
\hline & PBCV1 $\mathrm{CH}-57$ & $\mathrm{CH}$ & FW & 1997 & AF344210 \\
\hline & PBCV1 CVA-1 & n.d. & $\mathrm{FW}$ & n.d. & AF344211 \\
\hline & $P B C V 1 C V B-1$ & n.d. & $\mathrm{FW}$ & n.d. & AF344212 \\
\hline & PBCV1 CVG-1 & n.d. & FW & n.d. & AF344213 \\
\hline & PBCV1 CVM-1 & n.d. & FW & n.d. & AF344214 \\
\hline & PBCV1 CVR-1 & n.d. & FW & n.d. & AF344215 \\
\hline & PBCV1 IL-2A & US & $\mathrm{PO}$ & 1983 & AF344216 \\
\hline & PBCV1 IL-2B & US & PO & 1983 & AF344217 \\
\hline & PBCV1 IL-3A & US & $\mathrm{PO}$ & 1983 & AF344218 \\
\hline & PBCV1 IL-3D & US & $\mathrm{PO}$ & 1983 & AF344219 \\
\hline & PBCV1 IL-5-2S1 & US & PO & 1984 & AF344220 \\
\hline & PBCV1 IS-10 & IS & FW & 1996 & AF344221 \\
\hline & $P B C V 1 M A-1 D$ & US & $\mathrm{RV}$ & 1984 & AF344222 \\
\hline & PBCV1 MA-1E & US & $\mathrm{RV}$ & 1984 & AF344223 \\
\hline & PBCV1 NC-1A & US & $\mathrm{RV}$ & 1983 & AF344224 \\
\hline & PBCV1 NC-1B & US & $\mathrm{RV}$ & 1983 & AF344225 \\
\hline & $P B C V 1 N C-1 C$ & US & $\mathrm{RV}$ & 1983 & AF344226 \\
\hline & PBCV1 NC-1D & US & $\mathrm{RV}$ & 1983 & AF344227 \\
\hline & PBCV1 NE-8A & US & ST & 1984 & AF344228 \\
\hline & PBCV1 NE-8D & US & ST & 1984 & AF344229 \\
\hline & $P B C V 1 N Y-2 A$ & US & RV & 1984 & AF344230 \\
\hline & $P B C V 1 N Y-2 B$ & US & RV & 1984 & AF344231 \\
\hline & PBCV1 NY-2C & US & RV & 1984 & AF344232 \\
\hline & PBCV1 NY-2F & US & RV & 1984 & AF344233 \\
\hline & PBCV1 NYb-1 & US & $\mathrm{RV}$ & 1984 & AF344234 \\
\hline & PBCV1 NYs-1 & US & RV & 1984 & AF344235 \\
\hline
\end{tabular}


(continuação)

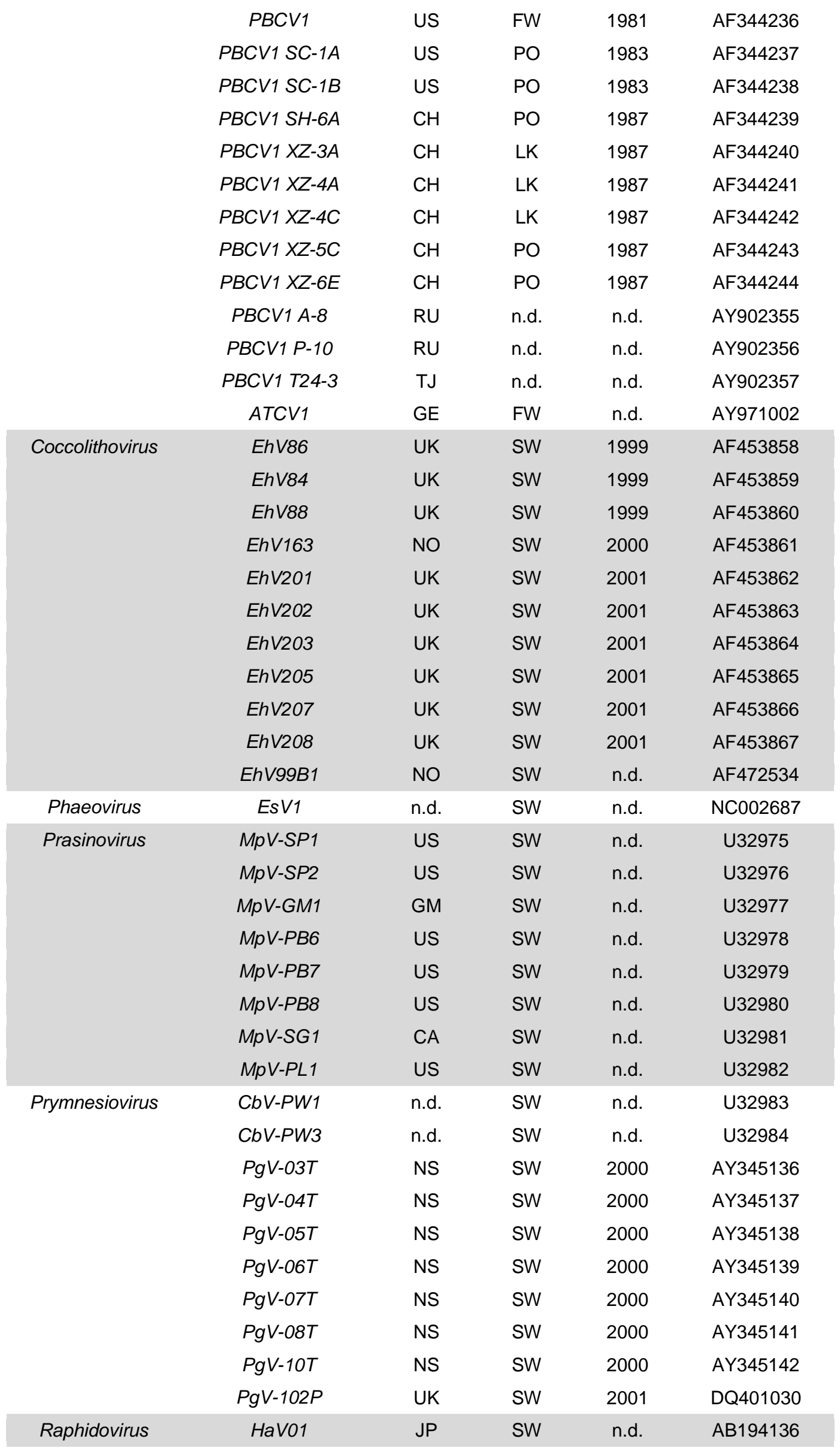


(conclusão)

Não classificado

\begin{tabular}{|c|c|c|c|c|}
\hline BpV82 & MS & SW & 2006 & FJ267513 \\
\hline BpV86 & MS & SW & 2006 & FJ267514 \\
\hline BpV87 & MS & SW & 2006 & FJ267515 \\
\hline BpV132 & MS & SW & 2006 & FJ267516 \\
\hline BpV161 & MS & SW & 2006 & FJ267517 \\
\hline BpV178 & MS & SW & 2006 & FJ267518 \\
\hline MiV93 & MS & SW & 2006 & FJ267493 \\
\hline MiV100 & MS & SW & 2006 & FJ267494 \\
\hline MiV130 & MS & SW & 2006 & FJ267495 \\
\hline OtV21 & MS & SW & 2006 & FJ267496 \\
\hline OtV22 & MS & SW & 2006 & FJ267497 \\
\hline OtV23 & MS & SW & 2006 & FJ267498 \\
\hline Otv66 & MS & SW & 2006 & FJ267499 \\
\hline OtV63 & MS & SW & 2006 & FJ267501 \\
\hline OtV64 & MS & SW & 2006 & FJ267502 \\
\hline OtV65 & MS & SW & 2006 & FJ267503 \\
\hline OtV3 & MS & SW & 2006 & FJ267504 \\
\hline OtV29 & MS & SW & 2006 & FJ267505 \\
\hline OtV52 & MS & SW & 2006 & FJ267506 \\
\hline OtV72 & MS & SW & 2006 & FJ267507 \\
\hline OtV78 & MS & SW & 2006 & FJ267508 \\
\hline OtV102 & MS & SW & 2006 & FJ267509 \\
\hline OtV113 & MS & SW & 2006 & FJ267510 \\
\hline OtV121 & MS & SW & 2006 & FJ267511 \\
\hline OtV126 & MS & SW & 2006 & FJ267512 \\
\hline PpV01 & NO & SW & n.d. & EU006634 \\
\hline PoV01 & NO & SW & n.d. & EU006633 \\
\hline
\end{tabular}

Origem: US - Estados Unidos; AU - Austrália; AR - Argentina; CH - China; IS - Israel; RU - Rússia; TJ-Tajiquistão; GE - Alemanha; NO - Noruega; UK - Reino Unido; GM - Golfo do México; CA Canadá; NS - Mar do Norte; JP - Japão; MS - Mar Mediterrâneo.

Ambiente: PO - lagoa; LK - lago; FW - água doce; ST - rio; DD - cano de drenagem; RV - rio e SW - mar. Para a análise de movimentação de ficodnavírus entre ambientes aquáticos, PO, LK e DD, foram considerados "lago" (L), ST e RV foram considerados "rio" (R), e a ambiguidade FW foi identificada por RL.

n.d.: Dado não disponível. 


\section{ANEXO E}

Sequências de clones ambientais usadas na reconstrução filogenética dos miofagos.

\begin{tabular}{|c|c|c|c|}
\hline $\begin{array}{c}N^{\circ} \text { acesso do } \\
\text { GenBank }\end{array}$ & Origem & Ambiente & Data \\
\hline $\begin{array}{c}\text { AB284329 ao } \\
\text { AB284345 }\end{array}$ & $J P$ & CS & 1998 \\
\hline $\begin{array}{c}\text { AB299989 ao } \\
\text { AB300032 }\end{array}$ & $J P$ & cS & 2006 \\
\hline $\begin{array}{c}\text { AB365540 aо } \\
\text { AB365568 }\end{array}$ & JP & CS & 2003 \\
\hline $\begin{array}{c}\text { AB365569 ao } \\
\text { AB365595 }\end{array}$ & JP & CS & 2006 \\
\hline $\begin{array}{c}\text { AB368379 aо } \\
\text { AB368422 }\end{array}$ & JP & CS & 2006 \\
\hline $\begin{array}{c}\text { AB373643 ao } \\
\text { AB373681 }\end{array}$ & JP & CA & 2005 \\
\hline $\begin{array}{c}\text { AB375934 ao } \\
\text { AB375983 }\end{array}$ & JP & CS & n.d. \\
\hline $\begin{array}{c}\text { AB428576 aо } \\
\text { AB428628 }\end{array}$ & $\mathrm{CH}$ & CS & 2007 \\
\hline $\begin{array}{c}\text { AB449975 ao } \\
\text { AB450279 }\end{array}$ & $J P$ & CS & 2007 \\
\hline $\begin{array}{l}\text { DQ105858 ao } \\
\text { DQ105905 }\end{array}$ & $\mathrm{CA}$ & SW & 1999 \\
\hline $\begin{array}{c}\text { DQ105907 ao } \\
\text { DQ105924 }\end{array}$ & AR & SW & 2002 \\
\hline $\begin{array}{c}\text { DQ105925 ao } \\
\text { DQ105942 }\end{array}$ & GM & SW & 2001 \\
\hline $\begin{array}{c}\text { EF617450 ao } \\
\text { EF617483 }\end{array}$ & n.d. & SW & n.d. \\
\hline
\end{tabular}

Origem: JP - Japão; CH - China; CA - Canadá; AR Ártico; GM - Golfo do México.

Ambiente: CS - campos de arroz (solo); CA campos de arroz (água) ; SW - mar.

n.d.: não disponível. 


\section{ANEXO F}

Isolados da família Myoviridae usados na reconstrução filogenética dos miofagos.

\begin{tabular}{ccc}
\hline \hline Hospedeiro & Fago & $\begin{array}{c}\text { No acesso do } \\
\text { GenBank }\end{array}$ \\
\hline Enterobacteria & $T 4$ & X01774 \\
Enterobacteria & $R B 49$ & NC_005066 \\
Vibrio & $K V P 40$ & NC_005083 \\
Aeromonas & $44 R R 2.8 t$ & NC_005135 \\
Synechococcus & S-PM2 & NC_006820 \\
Procholococcus & $P-S S M 2$ & NC_006883 \\
Procholococcus & $P-S S M 4$ & NC_006884 \\
Enterobacteria & $R B 32$ & NC_008515 \\
Enterobacteria & $P h i 1$ & NC_009821 \\
Enterobacteria & JS98 & EF469154 \\
Enterobacteria & $R B 69$ & AY303349 \\
\hline
\end{tabular}




\section{ANEXO G}

Identidade das sequências obtidas a partir de clones contendo DNA amplificado com os oligonucleotídeos AVS-1 e AVS-2 (supostamente ficodnavírus) comparadas com as sequências do GenBank através de análise com o blast (non-redundant) - nucleotídeo.

\begin{tabular}{|c|c|c|c|}
\hline $\begin{array}{c}\text { Identificação do } \\
\text { Clone }\end{array}$ & $\begin{array}{c}\text { Tamanho } \\
\text { (pb) }\end{array}$ & Maior Similaridade - blastp (nr) & Ev \\
\hline 1 a $19^{*}$ & 692 & peptidase M22 glycoprotease [Ralstonia pickettii 12J] & $2,00 \mathrm{E}-13$ \\
\hline 20 a $34^{*}$ & 531 & aspartate kinase [Flavobacterium johnsoniae UW101] & $1,00 \mathrm{E}-78$ \\
\hline 35 a $40^{*}$ & 354 & Superoxide dismutase [Flavobacterium johnsoniae UW101] & $1,00 \mathrm{E}-43$ \\
\hline 41 a $44^{*}$ & 674 & TraX family protein [Pseudomonas mendocina ymp] & $3,00 \mathrm{E}-20$ \\
\hline 45 a $46^{*}$ & 338 & peptidoglycan glycosyltransferase [Polynucleobacter sp. QLW-P1DMWA-1] & $7,00 \mathrm{E}-39$ \\
\hline 47 & 589 & CcdB protein [Expression vector pKIL-HIS3] & $4,00 \mathrm{E}-69$ \\
\hline 48 & 593 & ribose-phosphate pyrophosphokinase [Ralstonia solanacearum GMI1000] & $7,00 \mathrm{E}-41$ \\
\hline 49 & 432 & Pyridoxal-5'-phosphate-dependent enzyme, beta subunit [Flavobacterium johnsoniae UW101] & $1,00 \mathrm{E}-44$ \\
\hline 50 & 508 & lipid-A-disaccharide synthase [Flavobacteria bacterium BAL38] & $7,00 E-39$ \\
\hline 51 & 362 & Phospholipid/glycerol acyltransferase [Xylella fastidiosa Ann-1] & 2,2 \\
\hline 52 & 493 & Superfamily II DNA helicase [Yersinia mollaretii ATCC 43969] & $2,00 \mathrm{E}-34$ \\
\hline 53 & 621 & chorismate mutase / prephenate dehydratase [Methylobacillus flagellatus KT] & $5,00 \mathrm{E}-64$ \\
\hline 54 & 366 & glyceraldehyde 3-phosphate dehydrogenase [Mycoplasma arthritidis 158L3-1] & 4,2 \\
\hline 55 & 478 & hypothetical protein TWT389 [Tropheryma whipplei str. Twist] & $5,00 \mathrm{E}-08$ \\
\hline 56 & 513 & FG-GAP repeat protein [Delftia acidovorans SPH-1] & $5,00 \mathrm{E}-20$ \\
\hline 57 a $60^{*}$ & 673 & DNA polymerase [unknown phycodnavirus] & $2,00 \mathrm{E}-109$ \\
\hline 61 a $62^{*}$ & 672 & DNA polymerase [unknown phycodnavirus] & $1,00 \mathrm{E}-90$ \\
\hline 63 & 672 & DNA polymerase [unknown phycodnavirus] & $7,00 \mathrm{E}-119$ \\
\hline 64 & 672 & DNA polymerase [unknown phycodnavirus] & $6,00 \mathrm{E}-32$ \\
\hline
\end{tabular}

* Sequências com $98 \%$ de similaridade, as quais foram agrupadas na tabela

pb: tamanho do fragmento em pares de base

Ev: E value 


\section{ANEXO H}

Identidade das sequências obtidas a partir de clones contendo DNA amplificado com os oligonucleotídeos AVS-1 e AVS-2 (supostamente ficodnavírus), comparadas com as sequências do GenBank através de análise com o tblastx (non-redundant) - aminoácido.

\begin{tabular}{|c|c|c|c|c|}
\hline $\begin{array}{l}\text { Identificação do } \\
\text { Clone }\end{array}$ & $\begin{array}{l}\text { Tamanho } \\
\text { (pb) }\end{array}$ & Maior Similaridade - tblastx (nr) & Ev & $\begin{array}{r}\mathbf{R F} \\
\text { (aa) }\end{array}$ \\
\hline 1 a $19^{*}$ & 692 & Polynucleobacter sp. QLW-P1DMWA-1, complete genome & $9,00 \mathrm{E}-30$ & 130 \\
\hline 20 a $34^{*}$ & 531 & Flavobacterium johnsoniae UW101, complete genome & $4,00 \mathrm{E}-82$ & 176 \\
\hline 35 a $40^{*}$ & 354 & Flavobacterium johnsoniae UW101, complete genome & $9,00 \mathrm{E}-60$ & 145 \\
\hline 41 a $44^{*}$ & 674 & Pseudomonas syringae pv. syringae B728a, complete genome & $1,00 \mathrm{E}-10$ & 210 \\
\hline 45 e $46^{*}$ & 338 & Polynucleobacter sp. QLW-P1DMWA-1, complete genome. & $1,00 \mathrm{E}-47$ & 112 \\
\hline 47 & 589 & ORF selection vector pSOS plasmid pSOS, complete sequence. & $5,00 \mathrm{E}-118$ & 148 \\
\hline 48 & 593 & Polynucleobacter sp. QLW-P1DMWA-1, complete genome. & $5,00 \mathrm{E}-64$ & 167 \\
\hline 49 & 432 & Flavobacterium johnsoniae UW101, complete genome. & $8,00 E-52$ & 103 \\
\hline 50 & 508 & Flavobacterium johnsoniae UW101, complete genome. & $5,00 \mathrm{E}-39$ & 162 \\
\hline 51 & 362 & Phaeosphaeria nodorum SN15 hypothetical protein partial mRNA & 1,6 & 70 \\
\hline 52 & 493 & Sodalis glossinidius str. 'morsitans' DNA, complete genome. & $2,00 \mathrm{E}-36$ & 164 \\
\hline 53 & 621 & Methylobacillus flagellatus KT, complete genome & $7,00 \mathrm{E}-65$ & 206 \\
\hline 54 & 366 & PREDICTED: Danio rerio similar to PF6 (LOC561115), mRNA. & 0,13 & 121 \\
\hline 55 & 478 & Tropheryma whipplei str. Twist, complete genome & $4,00 \mathrm{E}-08$ & 125 \\
\hline 56 & 513 & Delftia acidovorans SPH-1, complete genome & 2,00E-09 & 170 \\
\hline 57 a $60^{*}$ & 673 & Unknown phycodnavirus clone CRb-39 DNA polymerase gene, partial cds. & $2,00 \mathrm{E}-128$ & 224 \\
\hline 61 e $62^{*}$ & 672 & Unknown phycodnavirus clone SPRa-01 DNA polymerase gene, partial cds. & $2,00 \mathrm{E}-136$ & 223 \\
\hline 63 & 672 & Unknown phycodnavirus clone SPRa-39 DNA polymerase gene, partial cds. & $6,00 \mathrm{E}-137$ & 223 \\
\hline 64 & 672 & Unknown phycodnavirus clone SPRa-38 DNA polymerase gene, partial cds. & $1,00 \mathrm{E}-116$ & 80 \\
\hline
\end{tabular}

* Sequências com $98 \%$ de similaridade, as quais foram agrupadas na tabela

pb: tamanho do fragmento em pares de base

Ev: E value

RF (aa): tamanho da maior reading frame, em número de aminoácidos 
ANEXO I

Alinhamento múltiplo das sequências de miofagos.

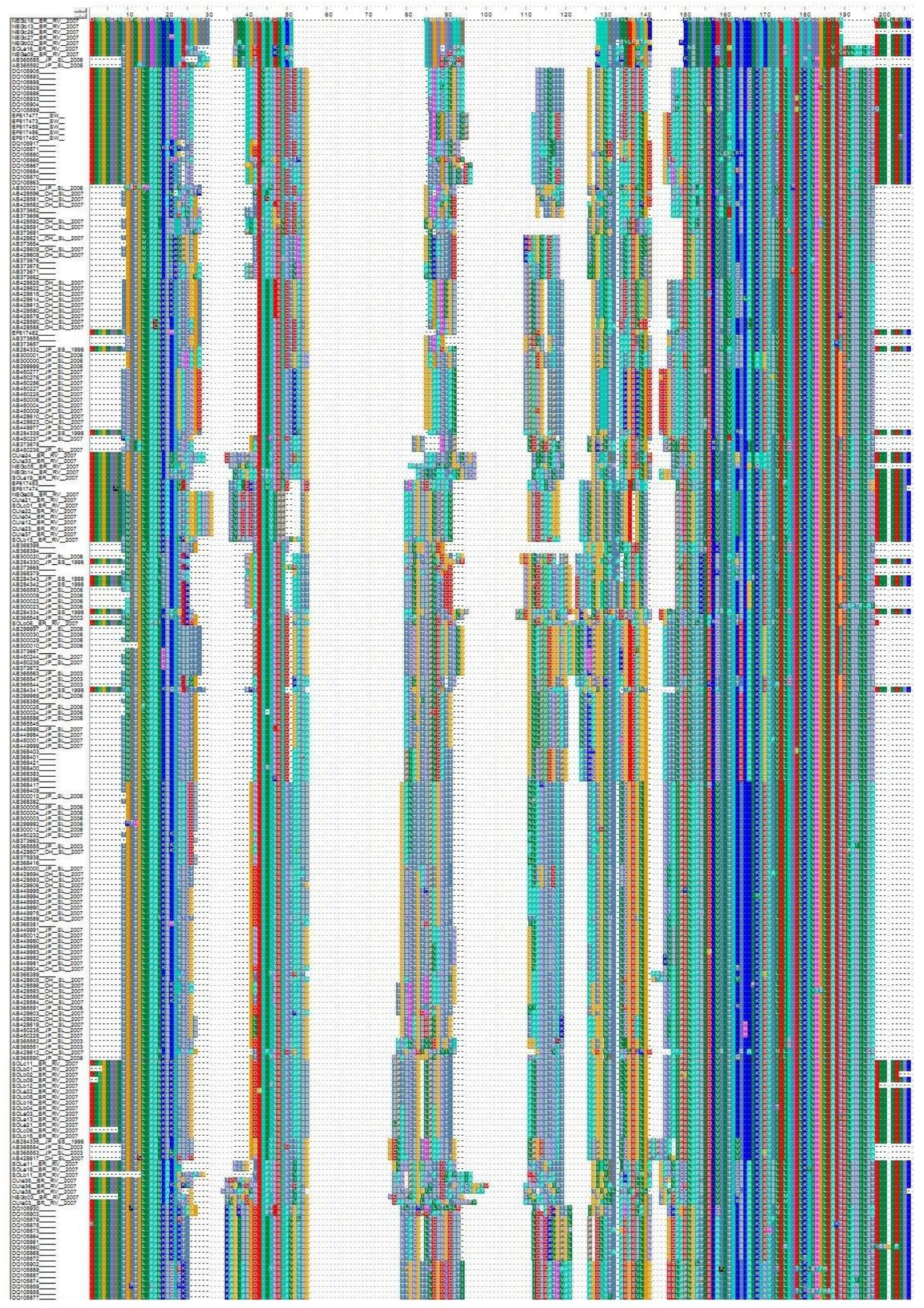




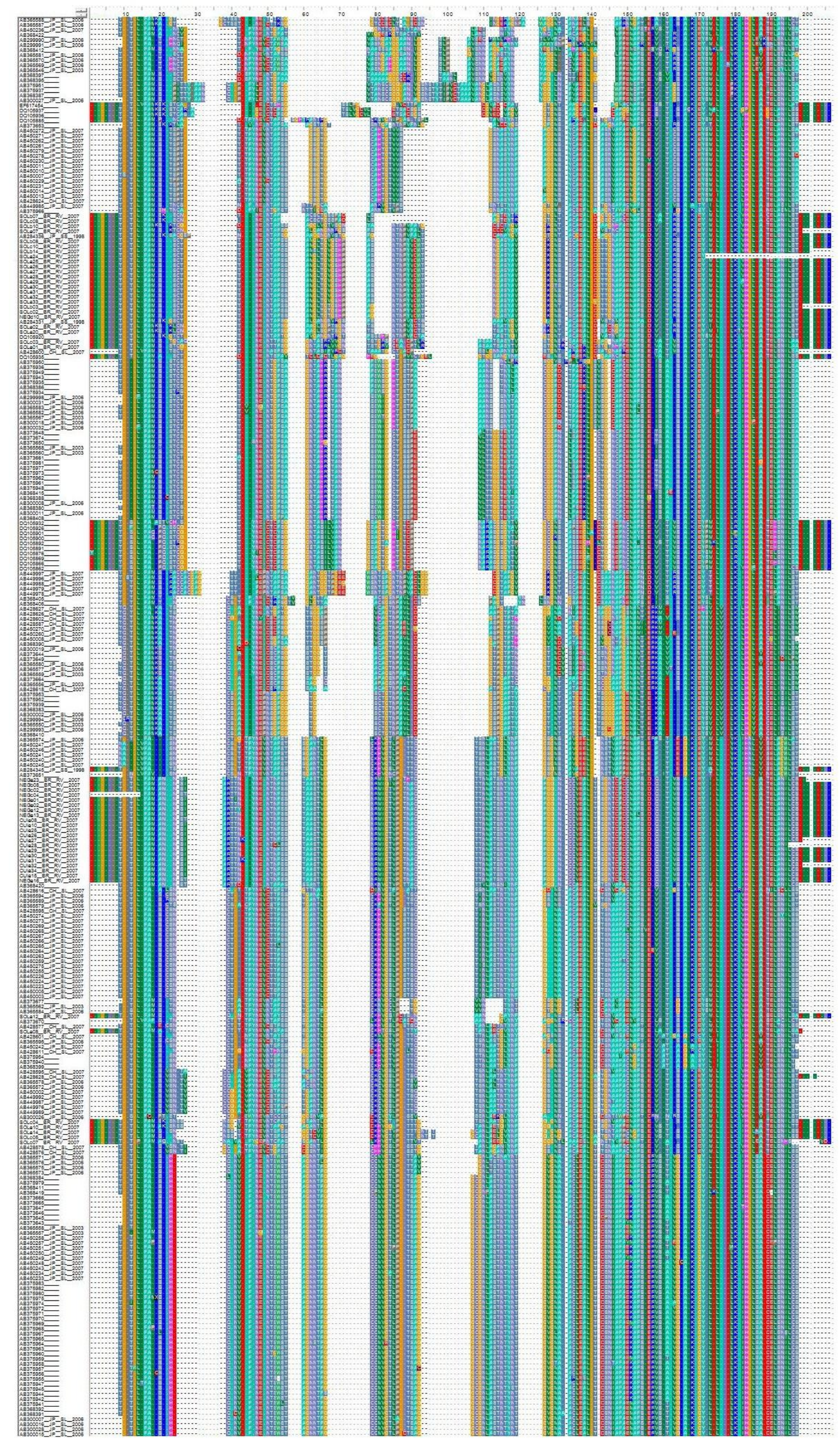




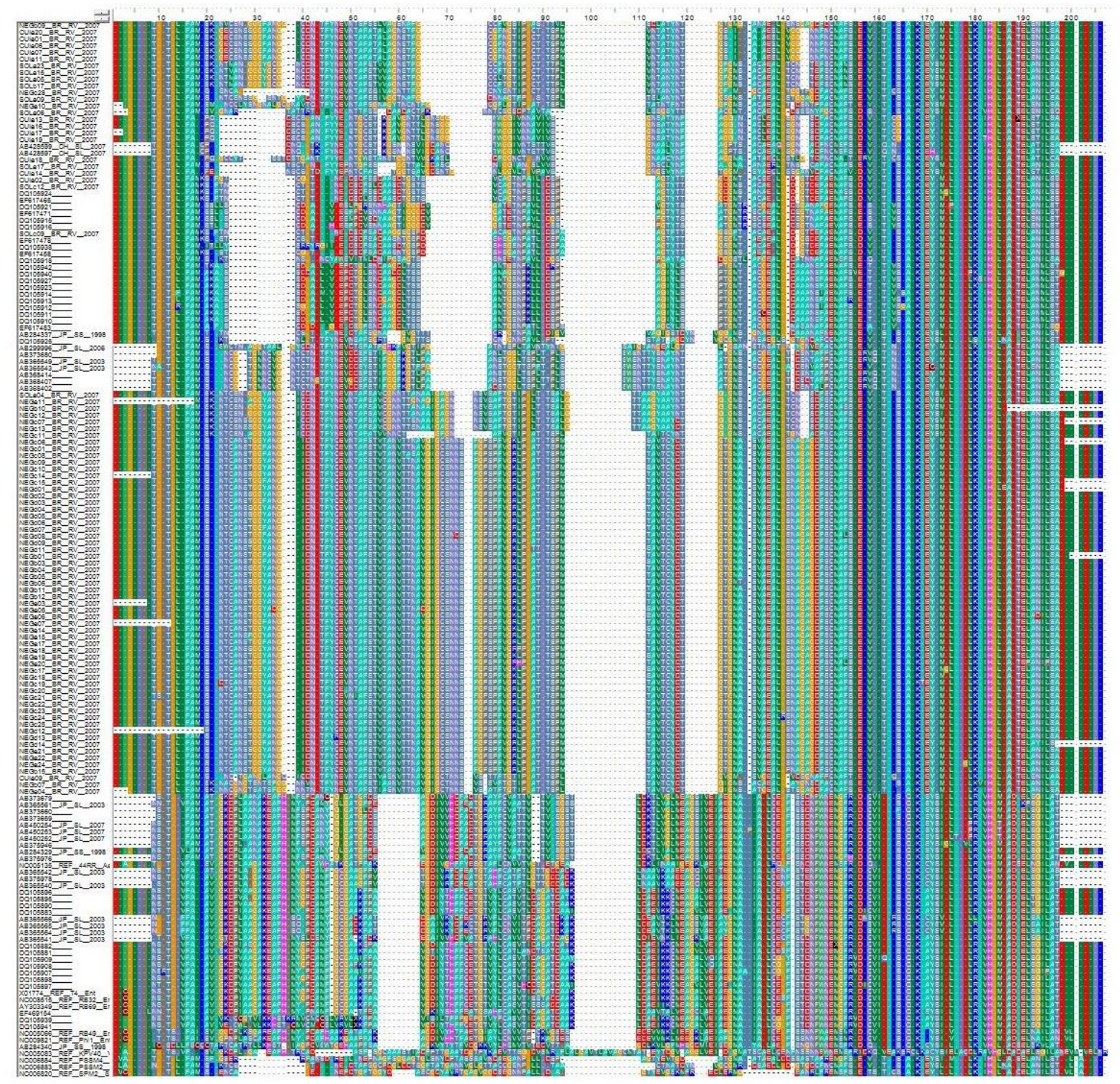

